ESTUDOS DE CARRAPATOS E PEQUENOS MAMÍFEROS SILVESTRES NATURALMENTE INFECTADOS COM * ESPIROQUETAS SEMELUANTES À BORRELIA, NO MUNICÍPIO DE ITAPEVI, ESTÅDO DE SÃO PAULO •
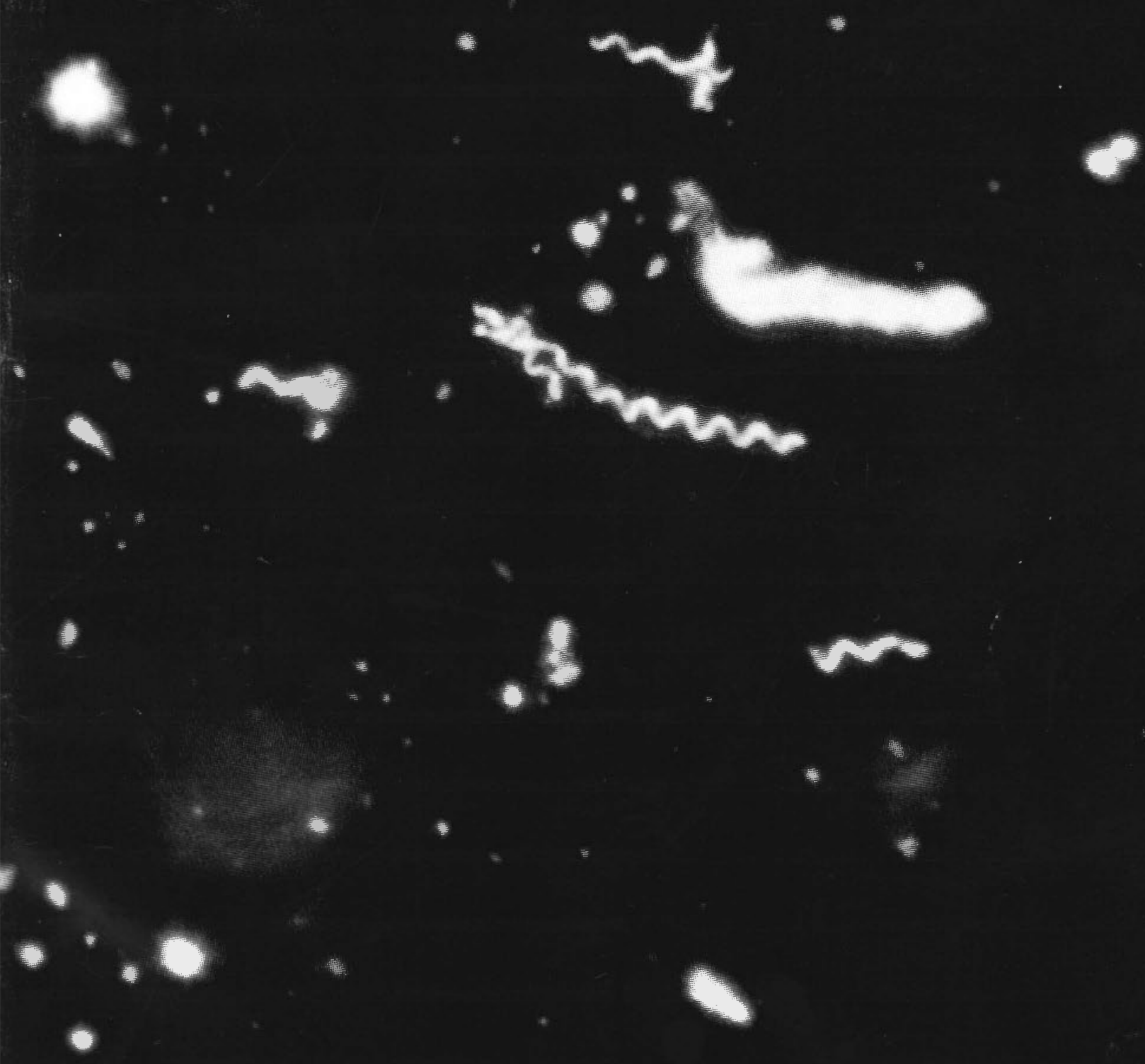

DARCI MORAES BARROS BATTESTI

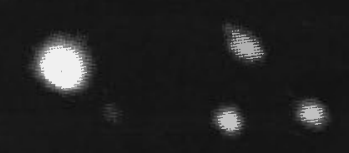




\section{ESTUDOS DE CARRAPATOS E PEQUENOS MAMÍFEROS SILVESTRES NATURALMENTE INFECTADOS COM ESPIROQUETAS SEMELHANTES À BORRELIA, NO MUNICÍPIO DE ITAPEVI, ESTADO DE SÃO PAULO.}

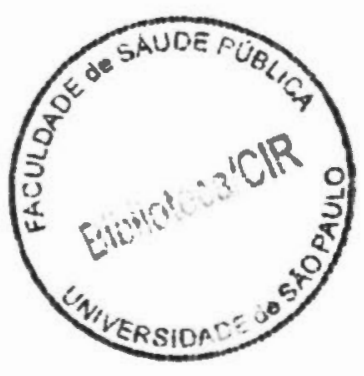

Tese apresentada ao Departamento de Epidemiologia da Faculdade de Saúde Pública Universidade de Săo Paulo, para obtençăo do título de Doutor em Saúde Pública.

ORIENTADOR: Prof. Dr. ALMÉRIO dE CASTRO GOMES

SÃo PAULO, SP

1998 
PAl

INFELIZMENTE VOCE PARTIU ...

NĀO HOUVE TEMPO PARA VOCE VER ESTE TRABALHO CONCLUIDO...

NEM MESMO PARA DESPEDIDAS ...

MAS SEI QUE ONDE VOCE ESTA, SEU BRILHO E TATO INTENSO

QUANTO FOI SUA LUZ, GUIANDO-ME NESTE CAMINHO

MINHA ETERNA GRATIDĀO POR SEU EXEMPLO DE CARÁTER E DIGNIDADE 
À Emilia, minha mãe, pela sua sabedoria e serenidade ao me proporcionar o melhor na vida.

Aos meus irmãos e familiares, pelo amor, estimulo e confiança em todos os momentos.
À Bruna, minha filha querida, sempre esperando com paciência um pouquinho da minha presença.

Aos filhos do coraçăo Rafael, Ligia e Bruno, pelo carinho.

Ao Octavio, pelo apoio incondicional e por muito amor recebidos para a realização dos meus sonhos. 


\section{AGRADECIMENTOS}

Ao Dr. Almério de Castro Gomes, pelas críticas, sugestões e orientação no planejamento e execução da tese.

Ao Conselho Nacional de Desenvolvimento Cientifico e Tecnológico, CNPq, pela concessão da bolsa de doutorado durante o primeiro ano de curso.

Ả Coordenação do Curso de Pós-Graduação da Faculdade de Saúde Pública da USP e à Secretaria do Departamento de Epidemiologia pela excelente organizaçāo, sempre permitindo aos alunos a liberdade de ação.

Ao Instituto Brasileiro do Meio Ambiente, IBAMA-SP, pela autorização de coleta de pequenos mamiferos.

À administração e moradores do Condomínio Residencial Transurb pela permissão de coleta nas áreas peridomiciliares. Ao Wanderlei e Valdir Nery de Souza pelo auxílio no armadilhamento e captura dos mamíferos.

À Companhia de Saneamento Básico do Estado de São Paulo (SABESP), na pessoa de José Roberto Nali, encarregado do sistema de tratamento de água da estação Morro Grande, pelo fornecimento dos dados pluviométricos.

Ao Laboratório de Investigação em Doença de Lyme da Faculdade de Medicina da USP. Ao mestre e amigo Natalino Hajime Yoshinari pioneiro nos estudos clínicos e sorológicos da doença de Lyme no Brasil, o meu profundo reconhecimento pelo ensinamento, confiança e estímulo naqueles momentos mais difíceis. Aos amigos Virginia Lúcia Nazario Bonoldi pela imensa contribuição na preparaçăo dos meios de cultura e de todo o material biológico, Márcia Ishikawa, Elaine Leon e Alexandre Zeitune pelo auxílio em campo e laboratório. À Giancarla Gauditano, Isaias P. Costa e Paulo José L. Barros pelas criticas, sugestões e colaboração nas pesquisas sobre a borreliose.

Ao Laboratório de Prática em Saúde Pública da Faculdade de Saúde Pública da USP, pelo empréstimo do microscópio de campo escuro e, em especial, às amigas Maria Ivette $\mathrm{C}$. Malucelli e Maria $\mathrm{H}$. Matté pelas técnicas de coloração das lâminas e sugestões para melhorar os meios de cultura.

Ao Museu de História Natural Capão da Imbuia, Departamento de Zoológico da Prefeitura Municipal de Curitiba, PR, onde fui servidora entre 1988 a 1994, pela amizade dos diretores Marcio L. Bittencourt, Pedro Scherer Neto, J. Tadeu W. Motta, L. Roberto Francisco e Gilda Tebet. A todos os funcionários do museu pelo carinho, mas em especial aos amigos Michel Miretzki pelas identificaçōes dos mamiferos, Márcia Arzua pela colaboração nos estudos de 
ectoparasitos, Rosana Ferrando no preparo do material ectoparasitológico, Teresa Cristina $\mathrm{C}$. Margarido e Rogério Lange pela qualidade fotográfica dos mamíferos e ao taxidermista, Sebastiăo C. Pereira, pelo excelente trabalho.

Ao Mestre Domingos Baggio (in memoriam) por sua dedicaçăo à acarologia, tendo incentivado, através dos seus conhecimentos, nosso aprendizado em ixodologia. À professora Teresinha T. S. Schumaker do Departamento de Parasitologia, ICB-USP, pela oportunidade de estágio em seu laboratório e auxilio nas despesas com os trabalhos de campo. Aos amigos Sueko Higa de Lima pelo imenso carinho e colaboração e Luiz Pereira da Silva sempre dedicado e presente durante todas as fases de coletas.

Ao amigo Ricardo Pinto da Rocha do Museu de Zoologia da USP, pelo incentivo aos estudos de acarologia, colocando-nos em contato com o professor Domingos Baggio para a realização de estágio em acarologia médica.

Ao Departamento de Epidemiologia e Saúde Pública em Doenças Parasitárias da Universidade Federal Rural do Rio de Janeiro, na pessoa do professor Advaldo Henrique Fonseca pela orientação, amizade e oportunidade de estágio em seu laboratório, bem como, por sua contribuição ao lado do amigo Cleber $\mathrm{O}$. Soares, na realização dos ensaios sorológicos em gambás.

Aos professores Eunice A. Bianchi Galati, Delcio Natal e José M. Soares Barata do Departamento de Epidemiologia, FSP-USP pelos ensinamentos nas aulas da pós-graduaçāo. Aos colegas Paulo R. Urbinatti e Walter Ceretti Jr. do Laboratório de Triatomíneos e Culicídeos pela amizade e auxílio fotográfico.

À Angela Maria Belloni Cuenca, do Serviço de Acesso à Informaçảo, Biblioteca da FSP-USP, pela correção das referéncias bibliográficas.

A todos os funcionários do Laboratório de Artrópodes do Instituto Butantan, pelo apoio durante todas as estapas desta tese. Aos colegas Roberto H. Pinto Moraes pela excelente qualidade das fotografias dos carrapatos, Rogério Bertani pela reprodução fotográfica da área de estudo e Kátia M. Faria pelo desenho esquemático do condomínio. À Sylvia M. Lucas, pela compreensão durante minha ausẻncia. Aos amigos Hilton F. Japyassu, Antonio Brescovit, Irene Knysak e Rosana Martins pelo carinho, críticas e sugestర̋es na elaboraçăo final do trabalho. À Cristina A. Rheims, pela revisão do Resumo em inglês.

Ao Otavio A. V. Marques do Laboratório de Herpetologia do Instituto Butantan e Carlos R. Bertim pelas criticas sobre a ecologia dos animais capturados na área de estudo. estatísticas.

À Monica Domeneck, pelo assessoramente e revisão das análises 
Ao biólogo Sérgio Antonio B. do Nascimento e ao Professor Dr. Antonio Sesso, do Laboratório de Patologia Molecular da Faculdade de Medicina da USP pela preparação do material microbiológico para ser processado em microscópio eletrónico de varredura.

A Marli Ueda, responsável pela Seção de Microscopia Eletrònica da Divisão de Biologia Médica do Instituto Adolpho Lutz, pelas inúmeras tentativas de fotografar o material microbiológico em microscópio eletrônico de transmissão.

A todos os meus familiares e em especial à Márcia Barros Scaranello pela amizade e estimulo em todos os momentos. 


\section{ÍNDICE}

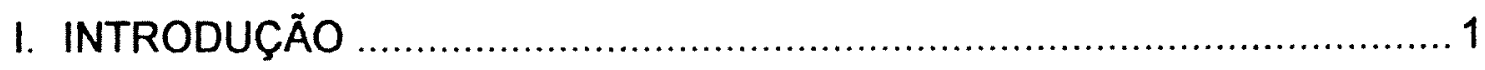

I.1. Espécies brasileiras do gênero Ixodes (Ixodinae: Ixodidae) ......7

1.2. Zoonoses transmitidas por carrapatos ..................................... 10

1.3. As principais espiroquetas patogènicas ................................12

1.4. Gênero Borrelia (Spirochaetaceae: Spirochaetales) .................13

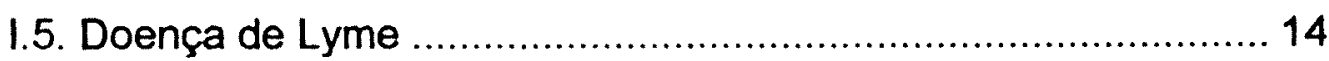

1.5.1. Ciclo epidemiológico e enzoótico da doença de Lyme ...... 16

1.5.2. Distribuiçăo global ....................................................... 19

1.5.3. Situação da doença de Lyme no Brasil ............................ 20

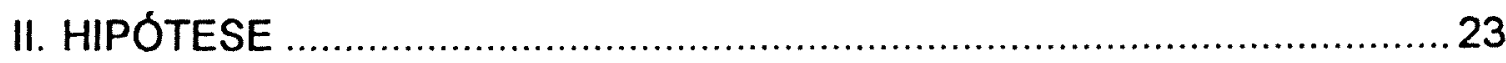

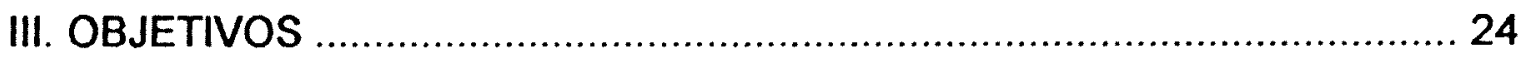

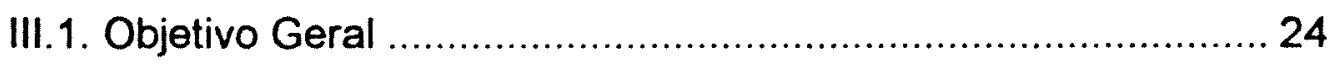

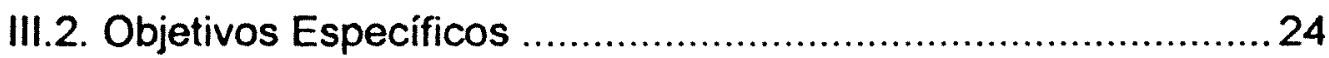

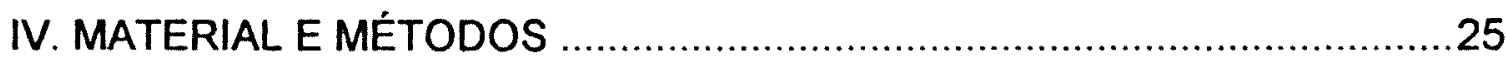

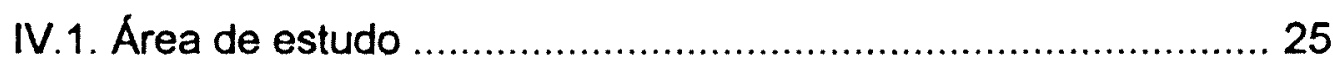

IV.2. Coleta de material - Identificaçăo hospedeiro/parasito ............ 28

IV.3. Processamento do meio de cultura de BSK - Kelly, Stoenner, Barbour (Barbour, 1984) …............................................... 30

IV.4. Preparação e análise do material biológico ............................30

IV.5. Tratamento estatístico .......................................................... 32 
IV.5.1. Índices de densidade relativa de mamiferos $\theta$ carrapatos 32

IV.5.2. Aplicação dos coeficientes de correlação de Spearman

e Pearson - Teste de Fisher e Qui-quadrado 32

IV.6. Instituições de Apoio 34

V. RESULTADOS 35

V.1. Espécies de mamiferos e carrapatos - Relação parasito/ Hospedeiro 35

V.1.2. Distribuição mensal e sazonal de mamiferos e carrapatos 43

V.1.3. Prevalència mensal e índices de infestação .................... 56

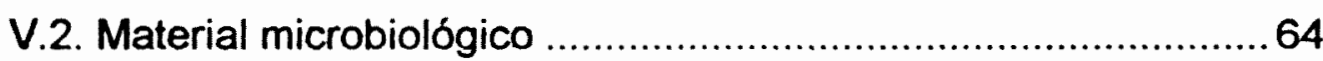

VI. DISCUSSÃO 83

VI.1. Considerações bioecológicas de carrapatos e pequenos mamiferos 83

VI.2. Sazonalidade da infecção em mamíferos e carrapatos 89

VI.3. Vigilância epidemiológica em áreas endêmicas 93

VI.4. Avaliação da situação de riscos de infecção em humanos .96

VII. CONCLUSOES 101

VIII. ABSTRACT 102

IX. REFERÊNCIAS BIBLIOGRÁFICAS 104 


\section{RESUMO}

Diversos casos humanos de borreliose de Lyme foram encontrados em diferentes regiões brasileiras entre 1990 e 1995. Quatro destes casos foram registrados nos município de Cotia e Itapevi, Estado de São Paulo. A proposta deste estudo, foi contribuir para elucidar os aspectos de transmissão da borreliose, em um condomínio residencial no município de Itapevi, SP, onde foram registrados os primeiros casos humanos com quadro clínico e sorológico compatíveis com a doença de Lyme. Os focos naturais de espiroquetas foram estudados no periodo entre Janeiro/1995 e Junho/1996. Um total de 134 pequenos mamiferos e 88 carrapatos coletados nestes hospedeiros foram investigados. Os carrapatos adultos foram identificados como Ixodes didelphidis, Ixodes loricatus e Amblyomma cajennense e os estágios imaturos como Ixodes sp. Para ambos, hospedeiros e carrapatos, foi calculado o indice de densidade relativa e correlacionado com dados meteorológicos pelos coeficientes de Spearman e Pearson. Para marsupiais e carrapatos estas correlações não foram significantes. Para roedores as correlações foram significantes $\theta$ diretamente relacionadas às baixas temperaturas $\theta$ índices pluviométricos $(p<0.05)$. A maior freqüência de carrapatos imaturos ocorreu na estação seca, principalmente em roedores; entretanto, carrapatos adultos predominaram durante a estação chuvosa, ocorrendo somente em marsupiais. Sangue e órgãos dos hospedeiros e carrapatos foram inoculados em meio BSK. Foram observadas espiroquetas semelhantes à Borrelia em culturas de sangue de $13 \%$ dos marsupiais da espécie Didelphis marsupialis e em $36.4 \%$ dos carrapatos coletados neste hospedeiro. Espiroquetas foram também observadas em $9.7 \%$ das culturas de sangue e órgãos dos roedores Akodon cursor, Bolomys lasiurus e Oxymycterus hispidus e em 30.3\% dos carrapatos coletados nestes hospedeiros. Os mamíferos e carrapatos adultos infectados ocorreram principalmente na estação chuvosa e os carrapatos imaturos infectados somente na estação seca. Há fortes evidências de que estas espiroquetas 
pertençam ao gênero Borrelia: Foram encontradas em pequenos mamíferos $\theta$ carrapatos; cresceram em meio inoculado com material proveniente de larvas de Ixodes coletadas em roedores näo infectados, sugerindo transmissão transovariana e crescem em meio característico para Borrelia.

Palavra-chave: espiroquetas de carrapatos - espiroquetas de mamiferos - focos naturais - borreliose de Lyme. 


\section{INTRODUÇÃO}

$\mathrm{Na}$ classificação mais recente apresentada por Oliver Jr. (1989) e mantida por Klompen et al. (1996), os carrapatos estão compreendidos na Subclasse Acari da Classe Arachnida, Ordem Parasitiformes, Subordem Ixodida, Superfamilia Ixodoidea. Das 35.000 espécies de ácaros descritas no mundo e, aproximadamente um milhão por descrever, cerca de 825 espécies descritas săo de carrapatos (Oliver Jr., 1989).

Embora todos os carrapatos sejam hematófagos, $90 \%$ deles são ectoparasitos especificos de animais onde o homem năo está incluído. As espécies consideradas de importância médica e veterinária, envolvidas na epidemiologia de doenças entre humanos e animais, representam os $10 \%$ restantes (Woolley, 1987; Oliver Jr., 1989).

Os carrapatos são ectoparasitos hematófagos altamente especializados e durante os curtos ou longos periodos em que as espécies vivem fora do hospedeiro, sua sobrevivência depende de um delicado intercambio entre os fatores fisiológicos, funcionais, estruturais e ecológicos. Assim, as relações carrapatos-hospedeiros e carrapatos-fatores ambientais, são ambas extremamente importantes para a compreensão do papel individual de cada espécie como parasito e vetor. Por outro lado, somente através do conhecimento das semelhanças e diferenças biológicas e fisiológicas entre as espécies, gêneros e familias, relacionadas ao hospedeiro e ao meio ambiente, é possivel avaliar a importanncia epidemiológica das espécies e o método de controle na prevenção de doenças (Hoogstraal, 1985).

A Superfamília Ixodoidea compreende três Familias: Argasidae, Ixodidae e Nuttalliellidae. As teorias hipotéticas tradicionais de Hoogstraal, Pomerantsev, Morel e Filippova, sobre a origem dos carrapatos e a especificidade com o hospedeiro, foram muito bem discutidas por Klompen et al. (1996). Apesar de muitas controvérsias, estas teorias foram baseadas na especificidade com 0 
hospedeiro e na coespeciação, mas nenhuma delas foi adequadamente testadas (Klompen et al., 1996).

Assim, segundo Hoogstraal (1978), estas famílias originaram-se de um ramo da Ordem Parasitiformes como parasitos de Reptilia no final do Paleozóico superior ou no Mesozóico inferior, há aproximadamente 225 milhóes de anos, sugerindo proximidade dos carrapatos ancestrais com os Argasidae atuais. Posteriormente, estes carrapatos irradiaram originando as famílias Argasidae e Ixodidae. Dentro da família Ixodidae, o grupo Prostriata foi o mais primitivo a se diferenciar da forma ancestral. Entre os Metastriata, a subfamilia Amblyomminae originou-se com répteis no final do periodo permiano, irradiando ao mesmo tempo que o hospedeiro durante o Triássico e o Jurássico (Mesozóico); as subfamilias Haemaphysalinae e Hyalomminae irradiaram respectivamente, no Triássico e final do Cretaceo e Rhipicephalinae somente no Terciário quando aves e mamíferos superaram os répteis (Hoogstraal, 1985).

Pomerantsev (appud Klompen et al., 1996) postulou que os hospedeiros ancestrais para lxodidae não foram répteis mas sim mamíferos e aves e que as espécies endẻmicas australianas de Ixodes (Prostriata), foram associadas primitivamente a monotremados e marsupiais.

Morel (appud Klompen et al., 1996) sugeriu que o gênero Amblyomma (Metastriata) foi o mais primitivo, estando associado a tartarugas no Jurássico.

Filippova (appud Klompen et al., 1996), assumiu que a origem dos Ixodidae ocorreu no Cretáceo e que estes carrapatos ancestrais foram associados aos monotremados e marsupiais.

Entretanto, segundo Oliver Jr. (1989), os registros mais antigos de fósseis de carrapatos (Parasitiformes) contrastam com o grupo irmão (Acariformes) cujos fósseis datam do Devoniano. Considerando que a subclasse Acari é de origem monofilética, então os grupos irmãos Parasitiformes e Acariformes devem ter idades semelhantes, sendo mais provável que os carrapatos tenham surgido no início do Devoniano (350 a 400 milhōes de anos atrás). Esta, foi a primeira hipótese no sentido de que a idade dos carrapatos 
não é somente dependente da idade do hospedeiro, sugerindo que o grupo ancestral dos Ixodida foi provavelmente um predador, como ocorre em todas as ordens de Arachnida. Segundo este autor, quando os carrapatos abandonaram - hábito predatório tornando-se ectoparasitos, seus principais hospedeiros foram provavelmente os Amphibia e não Reptilia.

Para testar todas as teorias acima sobre a origem e especificidade dos carrapatos, Klompen et al. (1996) propuseram uma comparaçăo entre a filogenia tradicional e a filogenia molecular, revelando uma nova interpretação que vem contribuir substancialmente para os agrupamentos e diversidade dos taxa. Por exemplo as três famílias, Argasidae, Ixodidae e Nuttaliellidae, cuja monofilia não havia ainda sido questionada, torna-se agora abalada quando a filogenia molecular revela a possibilidade de parafilia em Argasidae $e$, dentro desta família, a análise molecular demonstrou que subfamilia Argasinae encontra-se mais próxima aos Ixodidae do que a subfamilia Ornithodorinae. Com relação à especificidade do parasita com o hospedeiro, os autores ressaltaram que a evolução do carrapato pode ter sido amplamente determinada a um particular tipo de hábitat e não a adaptação a um particular taxon de hospedeiro, baseando-se na observação de que muitas espécies de carrapatos parasitam hospedeiros filogeneticamente distantes, porém com tipos semelhantes de hábitats como ninhos, tocas e ocos de árvores.

A Família Argasidae, a primeira linha filogenética, contém aproximadamente 170 espécies descritas para as duas Subfamilias, Argasinae (com 57 espécies para o gênero Argas) e Ornithodorinae (com 114 espécies distribuidas nos géneros Ornithodoros, Otobius e Carios). Pela filogenia molecular, os gèneros Antricola, Nothoaspis, Argas associados a morcegos $\theta$ uma parte de Ornithodoros, estão combinados com o gẻnero Carius, e o género Alveonasus é agora considerado um subgênero de Argas (Klompen et al., 1996).

Os argasídeos contemporâneos, conhecidos como carrapatos moles "soft ticks" devido a ausência de escudo, são mais abundantes em habitats áridos e 
semi-áridos, vivendo em ninhos e tocas dos hospedeiros, nos quais se alimentam múltiplas vezes. O ciclo de vida compreende ovo, larva, vários estágios ninfais e adultos machos e fêmeas. Na maioria das espécies, ninfas e adultos alimentam-se rapidamente (cerca de 30 a 40 minutos em média) enquanto larvas fixam-se aos hospedeiros por 7 a 10 dias. Para cada estágio imaturo ocorre uma refeição antes de cada ecdise, salvo raras exceçס̃es em que pode haver dois repastos sangüíneos em ninfas antes da muda. Adultos, no entanto, alimentam-se múltiplas vezes, geralmente antes das cópulas e oviposição (Hoogstraal, 1985; Woolley, 1987).

A Família Ixodidae, a segunda maior linha filogenética, é dominante com 13 gêneros e 650 espécies arranjadas em dois grandes grupos, consistindo de cinco Subfamilias (Hoogstraal \& Aeschlimann, 1982): Grupo Prostriata, subfamilia Ixodinae ( 1 gênero, 240 espécies); e Grupo Metastriata com as subfamílias Amblyomminae (2 gêneros, 125 espécies), Haemaphysalinae (1 gênero, 147 espécies), Hyalomminae (1 gènero, 22 espécies) e Rhipicephalinae (8 gêneros, 119 espécies). Esta classificação é contestada por Filippova (1984), que considera apenas duas Subfamilias: Ixodinae (Prostriata) e Amblyomminae (Metastriata).

A sistemática molecular baseada na seqüência de DNA ribossômico mitocondrial revelou correlações biogeográficas importantes em todos os niveis taxonômicos de Ixodidae, demonstrando fortes evidências de que esta família originou-se na Austrália. Se esta hipótese estiver correta, a estimativa da idade dos Ixodidae seria há cerca de 120 milhões de anos (Klompen et al., 1996), confirmando a hipótese de Filippova (appud Klompen et al., 1996) de que a origem do gênero lxodes ocorreu no final do Cretáceo.

Os representantes contemporâneos de Ixodidae, conhecidos como carrapatos duros "hard ticks" por apresentarem escudo, têm ampla distribuição, como parasitos de vertebrados. Quando estão fora do hospedeiro (fase não parasitária entre mudas), são encontrados nos mais variados ambientes. 
O ciclo de vida inclui ovo, larva, apenas um estágio ninfal e adultos. Cada estágio requer vários dias de fixação no hospedeiro e longos repastos sangüíneos. Há uma alimentaçăo em cada fase antes da muda. As fêmeas sugam uma única vez grande quantidade de sangue para a produção de milhares de ovos, os quais são postos numa única oviposição, morrendo em seguida. Geralmente, os machos alimentam-se intermitentemente, sugando pouca quantidade de sangue, permanecendo no hospedeiro por semanas ou meses (Oliver Jr., 1989).

Poucas espécies de lxodidae desenvolvem seu ciclo em um ou dois hospedeiros. No primeiro caso, todo o ciclo se processa no hospedeiro até atingir a fase adulta e, depois da cópula as fèmeas ingurgitam e caem no solo para a postura. No segundo caso, as larvas podem permanecer no hospedeiro após alimentaçăo, sofrem ecdise mudando para ninfas $e$, somente após o repasto sangüíneo caem no solo onde sofrem a muda para adultos, voltando a procurar o hospedeiro para fazer a última alimentação e cópula, caindo no solo para a oviposiçăo. Porém, a maioria dos Ixodidae tem três hospedeiros sendo que, freqüentemente, as fases imaturas alimentam-se em animais de pequeno porte, enquanto ingurgitam e realizam a cópula em animais de médio e grande porte. Todas as mudas e oviposição ocorrem no solo (Oliver Jr., 1989).

Aves, répteis e anfíbios săo hospedeiros para muitas espécies de Ixodidae, mas em geral, os ixodídeos alimentam-se em mamíferos, tendo pelo menos uma espécie de cada gênero nestes hospedeiros, dos quais Rodentia é o taxon mais parasitado. Mais de $50 \%$ das espécies de carrapatos nas fases jovens, sugam roedores (Woolley, 1987; Oliver Jr., 1989).

A família Nuttallielidae, de distribuição restrita à África do Sul e Tanzânia, pobremente estudada, tem apenas uma espécie descrita, Nuttalliela namaqua. A afiliação filogenética desta família monotípica, tem causado polêmica por meio século e, segundo Hoogstraal (1985) ela é um ramo independente da superfamilia Ixodoidea, por apresentar características únicas da espécie além de outras peculiares aos argasídeos e ixodídeos. Os machos desta espécie e o 
ciclo de vida, são desconhecidos. Os exemplares foram colhidos em um roedor (Otomyidae), pequeno carnivoro (Viverridae) e em ninhos de Hirundinidae (Bedford, 1934; Keirans et al., 1976).

Em geral, os carrapatos apresentam um ritmo definido para procura de hospedeiro, alimentação, desprendimento após alimentaçăo, diapausa e oviposição. A queda após ingurgitamento está associada ao período inativo do hospedeiro, quando estes encontram-se nos ninhos ou em outro local de descanso onde há proteção e um microhabitat favorável ao carrapato. Em fase de não parasitismo (entre mudas) os carrapatos requerem hábitats especializados para o seu desenvolvimento, bem como, oportunidade de encontrar hospedeiros para as próximas refeições. Esta especialização é estratégica para o seu ciclo de vida, especialmente no caso de espécies nidícolas como a maioria dos Argasidae e muitas espécies de lxodes (Beloserov, 1982).

Há comumente em Ixodoida representantes dos dois sexos e a relação sexual machoffêmea é de 1:1, embora em Argasidae, o dimorfismo sexual seja pouco aparente contrastando com Ixodidae onde o dimorfismo sexual é muito acentuado. A partenogènese é conhecida para poucas espécies e, em alguns argasideos, pode haver autogenia onde ocorre oviposição sem alimentaçăo (Oliver Jr., 1974).

$\mathrm{Na}$ natureza o ciclo de vida dos carrapatos é regulado sazonalmente ocorrendo, para a maioria das espécies, uma geração anual em regiōes subtropicais de climas temperados. Em regiões onde o inverno é rigoroso, pode levar vários anos para completar a geração (ovo-ovo), mesmo sem alimentaçăo (Oliver Jr., 1989).

As maiores contribuições sobre a fauna ixodológica brasileira datam, de pelo menos, três décadas atrás, registradas principalmente nas obras de Fonseca (1935a), Aragão (1936), Aragão \& Fonseca (1952, 1961). Estudos de carrapatos de aves e mamiferos em ambientes silvestres, foram ainda realizados por Guimarães (1945), Ribeiro (1966/1967), Oba \& Baggio (1977), 
Barros \& Baggio (1992), Arzua et al. (1994), Castro \& Serra-Freire (1996).

Excetuando os carrapatos que parasitam animais domésticos, são raros os estudos de biologia, ecologia e distribuição geográfica, sobre a grande maioria das espécies que parasitam animais silvestres no Brasil. Com relação à biologia, poucas espécies foram estudadas em condiçōes de laboratório, dentre elas, Amblyomma aureolatum ( $=$ A. striatum) (Fonseca, 1935b), Amblyomma rotundatum (Oba \& Schumaker, 1983), Amblyomma dissimile (Schumaker \& Barros, 1994), Ornithodoros talaje (Schumaker \& Barros, 1995). Entretanto, dados sobre epidemiologia de zoonoses transmitidas por carrapatos em ambiente silvestre, bem como sobre o comprometimento da sobrevivència dos hospedeiros e a veiculação de doenças, são pouco conhecidos para o Brasil. Algumas espécies estudadas, que podem atuar como transmissoras de patógenos entre animais silvestres e o homem, estão citadas em Aragão (1936), Davis (1952) e Flechtmann (1977), não havendo referências ao gênero Ixodes.

\section{I.1. Espécies brasileiras do gênero Ixodes (Ixodinae: Ixodidae)}

Algumas espécies podem, indistintamente, parasitar aves ou mamiferos em seus diferentes estágios de desenvolvimento; outras entretanto, apresentam maior especificidade com o hospedeiro, dependendo do seu estágio biológico. Klompen et al. (1996) consideram esta especificidade ecológica principalmente porque resulta de uma adaptação ao hábitat e não propriamente ao hospedeiro. Assim, na fase adulta, algumas espécies demonstram preferẻncia em parasitar mamíferos de médio e grande porte, estando as fases imaturas, associadas a pequenos mamíferos, principalmente roedores (Aragão, 1936; Cooley \& Kohls, 1945). Outras encontram-se estreitamente associadas às aves ou apenas ocasionalmente, mas desconhece-se o parasitismo de tartarugas ou anfíbios por Ixodes. Muitas espécies são importantes na transmissão de agentes patogênicos causando zoonoses e antropozoonoses (Keirans, 1992).

O gênero /xodes Latreille, 1795 inclui cerca de 240 espécies distribuídas em 14 subgêneros espalhados no mundo (Clifford et al., 1973; Keirans, 1992; 
Klompen et al., 1996). Dentro do gênero lxodes, um dos subgêneros é o subgênero /xodes, com aproximadamente 80 espécies distribuidas em todas as regiőes zoogeográficas, exceto a Australiana, cuja taxonomia está baseada na espécie tipo Ixodes ricinus (L.), 1758, formando o complexo I. ricinus (Clifford et al., 1973).

As espécies brasileiras de Ixodes listadas até 1961 por Aragão \& Fonseca (1961) eram 9:

I. amarali Fonseca, 1935; I. affinis Neumann, 1899 (=). ricinus aragaoi Fonseca, 1935; I. aragaoi Aragão \& Fonseca, 1952, Stat. n.); I. cooleyi Aragão \& Fonseca, 1954; I. coxaefurcatus Neumann, 1899; I. didelphidis Fonseca \& Aragão, 1951; I. fuscipes Koch, 1844; I. Ioricatus Neumann, 1899; I. Iuciae Senevet, 1940; I. schulzei Aragão \& Fonseca, 1951. Exceto para I. coxaefurcatus e I. didelphidis, as outras espécies foram incluídas por Clifford et al. (1973) dentro do subgênero Ixodes. As espécies I. coxaefurcatus e I. didelphidis não foram mencionadas por estes autores em nenhum subgênero e também não constam na listagem de espécies consideradas válidas por Keirans (1992).

A décima espécie do gênero Ixodes, I. auritulus Neumann, 1904, foi confirmada por Arzua et al. (1994) em aves Passeriformes de Curitiba PR e, recentemente em Columbiformes da mesma região geográfica (em preparação). Esta espécie pertence ao subgênero Multidentatus. Até então, este carrapato só havia sido coletado em aves Passeriformes da Serra de Itatiaia RJ, em 1922 (Cooley \& Kohls, 1945), porém estes exemplares não foram depositados em coleções brasileiras. Em outras regiōes zoogeográficas esta espécie está associada a aves marinhas (Clifford et al., 1973).

Barros-Battesti \& Knysak (1998), realizaram uma investigação sobre o material de Ixodes depositado na coleção acarológica do Instituto Butantan, considerada uma das mais importantes do Brasil. Os 154 lotes contendo 589 exemplares, foram coletados principalmente durante as décadas de 1930-1960 por Flávio da Fonseca. 
Este estudo, permitiu a verificação de hospedeiros e procedência para a maioria das espécies do gênero, bem como considerações sobre a validade de 1. didelphidis. Esta espécie é muito próxima de l. loricatus, não só pela morfologia mas também, pela preferência de hábitat e hospedeiro, apenas diferindo de l. loricatus, por possuir a placa peritremal maior com um número superior de fossetas (Fairchild et al., 1966), porém a espécie não foi sinonimizada. De qualquer modo, são necessários estudos biológicos clássicos e emprego de técnicas modernas de biologia molecular de ambas as espécies para avaliar se estas diferenças são intraespecificas ou interespecíficas (Klompen et al., 1996).

Com base no material depositado na coleção do Instituto Butantan, constatou-se que as fases imaturas são freqüentemente encontradas em roedores, enquanto que os exemplares adultos das espécies I. amarali, $I$. didelphidis, I. loricatus e I. luciae, têm preferẻncia por marsupiais. Poucos indivíduos adultos de $l$. schulzei estão depositados na coleção do Instituto Oswaldo Cruz e foram coletados em roedores silvestres procedentes de Santa Catarina e Rio de Janeiro, na década de 1950, não havendo mais registros de ocorrência. A espécie I. coxaefurcatus, com holótipo depositado na coleção do museu de Berlim, foi descrita por Neumann no século passado, de hospedeiro ignorado procedente da Serra Geral do Brasil, porém nunca mais foi encontrada. I. cooleyi, cujo lote tipo está depositado no Instituto Butantan, foi coletada em roedor silvestre da Bolivia, não constando exemplares brasileiros na coleção, embora figurando na listagem das espécies brasileiras publicada por Aragão \& Fonseca (1961). A espécie I. affinis, cujos exemplares foram coletados nos arredores do municipio de Cotia, SP (Fonseca, 1935a; Aragão \& Fonseca, 1952), com registros de ocorrência também para os Estados do Paraná e Rio Grande do Sul, tem como principais hospedeiros, animais de médio e grande porte tais como cães domésticos e veados. As espécies I. auritulus e I. fuscipes, foram coletadas em aves, porém I. fuscipes parece preferir roedores da familia Sciuridae. 
Dentre todas as espécies acima investigadas, seja através do material depositado no Instituto Butantan (Barros-Battesti \& Knysak, 1998), seja em estudos recentes no meio ambiente (Arzua et al., 1994 e manuscrito em preparaçăo), somente I. auritulus e uma espécie nova de Ixodes a ser descrita (em preparação), demonstraram preferência por hospedeiros da classe Aves.

Apesar da coleção do Instituto Butantan conter um número razoável de material de lxodes, nenhuma destas espécies foi encontrada em humanos no Brasil.

\subsection{Zoonoses transmitidas por carrapatos}

Os carrapatos transmitem mais variedade de agentes infecciosos do que qualquer outro grupo de artrópodes hematófagos (Hoogstraal, 1985). As toxinas e a maioria dos microrganismos são transmitidos aos vertebrados, principalmente através dos fluídos salivares inoculados enquanto o carrapato se alimenta.

Durante as mudas, os derivados da ectoderme e de certos músculos dos carrapatos sofrem histólise, as células e os órgãos internos alteram-se gradualmente, porém os alvéolos das glândulas salivares são completamente mantidos (Balashov, 1972). Muitos agentes infecciosos sobrevivem dentro do carrapato transestadialmente, desde o estágio larval ao ninfal e deste ao adulto.

A sobrevivẻncia transestadial é comum para vírus, riquetsias, bactérias e protozoários (Hoogstraal, 1985).

O carrapato pode também, atuar como reservatório, no qual o agente é um simbionte e sua sobrevivência depende somente da sobrevivência do carrapato-reservatório, sendo a transmissão transovariana um fenômeno primário da caracterização deste sistema (Oliver Jr., 1989).

As mudanças internas do carrapato, contribuem fundamentalmente para habilitar a replicaçăo e a transmissão de um grande número de microrganismos. Um carrapato suscetivel torna-se infectado quando se alimenta em um hospedeiro no qual o agente está circulante (via sistêmica), os chamados 
periodos de viremia, ricketsemia, espiroquetemia e bacteremia (Oliver Jr., 1989). Entretanto, Randolph et al. (1996) num estudo de transmissão de patógenos demonstraram um modelo alternativo de infecção para vírus e bactérias (via não-sistêmica). Neste modelo, a transmissão do patógeno ocorre quando carrapatos infectados e não infectados alimentam-se simultaneamente em proximidade espacial num mesmo hospedeiro, na ausência de uma infecção sistêmica no hospedeiro. Um carrapato não infectado pode também adquirir infecção de um local no hospedeiro que foi previamente utilizado por um carrapato infectado, principalmente em se tratando de patógenos que permanecem um tempo maior no local da inoculação antes da disseminação. A ocorrência de infecção via não-sistêmica foi observada recentemente com o agente etiológico da doença de Lyme por Gern \& Rais (1996).

As infecções com espiroquetas incluem doenças causadas por diversas espécies dentro de trés géneros: Treponema, Leptospira e Borrelia. Outros dois gêneros de espiroquetídeos, Spirochaeta e Cristispira, não são de interesse médico. Entre os três gẻneros causadores de doenças, somente Borrelia é transmitida através de artrópodes vetores.

Segundo Woolley (1987) os argasídeos são considerados menos importantes do que os ixodídeos na transmissão de doenças, mas atuam como vetores de arboviroses, riquetsias e, principalmente, borrelioses. As borrelias causadoras das borrelioses, conhecidas como "doença transmitida por piolho" e "doença transmitida por carrapato", durante muito tempo foram classificadas de acordo com a nomenclatura do vetor, cujo conceito de "um vetor-uma espécie" foi mantido, devido ao estreito relacionamento das linhagens especificas de borrelias com a espécie do vetor (Felsenfeld, 1965).

Seguindo este conceito, Davis (1952) ao estudar a biologia do argasídeo Ornithodoros brasiliensis Aragão, 1923, cujos exemplares foram coletados em São Francisco de Paula, RS, observou a presença de escassas espiroquetas no sangue do rato hospedeiro, entre o sexto e o décimo primeiro dia após ter sido utilizado para alimentar uma ninfa do lote original; tendo então denominado a 
espécie de Borrelia brasiliensis, baseando-se na morfologia das espiroquetas coradas e também no fato de terem sido transmitidas por carrapato do gênero Ornithodoros considerado bom vetor de borrelias.

\section{IV.3. As principais espiroquetas patogênicas}

Ao microscópio eletrônico, as espiroquetas possuem uma membrana parietocitoplásmica, de rigidez relativa, circundada por um envoltório externo elástico (periplasto), que permite a formaçăo de ondulações secundárias. Apresentam um aparelho locomotor interno situado entre o periplasto a a membrana parietocitoplásmica. Reproduzem-se por divisão transversal, comum a todas as eubactérias (Hovind-Hougen, 1976; Bier, 1985).

Segundo Fox et al. (1980), as espiroquetas, classificadas na Ordem Spirochaetales, representam um grupo mais antigo do ponto de vista filogenético que mereceria um nivel taxônomico mais apropriado como Classe ou Phylum. As razőes para tal especulação, baseiam-se na diversidade do ácido ribonucleico (RNA) e mapeamento de oligonucleotideos.

A morfologia de Treponema em esfregaços corados, revela filamentos espiralados delicados, de 4 a $18 \mu \mathrm{m}$ de comprimento, com 3 a 5 espiras e, quando observados em microscópio de campo escuro, exibem ativo movimento rotatório. Em microscópio eletrônico, o comprimento das espiras varia entre 0.9 a $1.8 \mu \mathrm{m}$, sendo constante para uma mesma espécie (Hovind-Hougen, 1976). A infecção ocorre por via direta.

O gênero Leptospira Noguchi, 1917, compreende microrganismos retilíneos ou encurvados, de 6 a $20 \mu \mathrm{m}$ de comprimento, largura de 0.1 a 0.15 $\mu \mathrm{m}$, com espiras curtas $(0.5 \mu \mathrm{m})$ de aspecto granular e uma ou ambas extremidades encurvadas em $C$ ou $S$, lembrando ganchos. $O$ aparelho locomotor é constituido por um único filamento espesso enrolado em hélice em torno do cilindro citoplásmico. A espécie tipo L. icterohemorrhagie (Inada \& Ido) Noguchi, 1917, possui vários sorotipos causadores das leptospiroses humanas 
e animais. A infecção ocorre por via direta ou indireta, através da pele e mucosas, por ingestão e contato de alimentos e águas contaminadas com a urina dos animais infectados (Bier, 1985).

\subsection{Gênero Borrelia (Spirochaetaceae: Spirochaetales)}

Borrelias são espiroquetas (gr. speira, espira e chaita, cabelo), cujas células são helicoidais, flexiveis e deformáveis durante o movimento. Distinguem-se dos espirilos (Spirillaceae) os quais são rígidos, indeformáveis (parede celular) e movem-se através de flagelos polares (Barbour \& Hayes, 1986). Estes autores consideram as características bioquimicas e ecológicas fundamentais para a identificaçăo do gênero Borrelia, observando que, o conteúdo de guanina-citosina do DNA genômico está entre 27 e $32 \%$. Freqüentemente são transmitidas transovarianamente no vetor $e$ todas as espécies do gênero săo transmitidas para vertebrados através de artrópodes hematófagos. Além destas características, a ultramicroscopia associada à bioquímica e imunoquímica, tem permitido por mais de uma década, a revelaçăo de estruturas ao nivel de gênero e espécie, proporcionando uma melhor compreensão da superfície e das organelas celulares.

As diferentes espécies de Borrelia variam em comprimento, diâmetro, regularidade e rigidez das espiras, bem como no número de flagelos. $O$ comprimento da célula varia desde $8 \mu \mathrm{m}$ para $B$. coriaceae, até mais de $20 \mu \mathrm{m}$ para B. burgdorferi (Burgdorfer et al., 1982; Hovind-Hougen, 1984), havendo também variação na amplitude das hélices, sendo as mais estreitas observadas para $B$. burgdorferi $(0.2$ a $0.3 \mu \mathrm{m})$ e as mais largas para $B$. recurrrentis $e B$. persica $(0.45$ e $0.5 \mu \mathrm{m})$.

Em regra, as medidas de largura săo mais apropriadas para a caracterização do que as de comprimento, uma vez que este, depende dos nutrientes e da idade do meio de cultura (Barbour \& Hayes, 1986). Estes autores observaram que, quando se adiciona glicose em uma cultura com 
espiroquetas, cujo meio está esgotado energeticamente, ocorre redução no comprimento das células e um aumento na amplitude das espiras.

O cultivo "in vitro" das borrelias é trabalhoso e difícil, requerendo um meio especialmente enriquecido e com pouco oxigênio (Kelly, 1971; Fraser et al., 1997). No caso específico de B. burgdorferi "sensu lato", agente etiológico da doença de Lyme, as células crescem lentamente. Schwan et al. (1988) e Norris et al. (1995), observaram que B. burgdorferi, quando cultivadas por muito tempo, perdem alguns plasmídios, alteram o perfil de expressão das proteinas, reduzindo sua capacidade de infectar animais de laboratório, sugerindo que os plasmídios codificam proteinas importantes envolvidas na virulência.

Os componentes estruturais de $B$. burgdorferi foram bem estudados por diversos pesquisadores (Barbour \& Hayes, 1986). A superfície externa da espiroqueta, associada intimamente à membrana externa, é coberta com um material de caráter lipoproteico comum a todas as borrelias (Fraser et al., 1997). A membrana externa de Borrelia sp., tem uma estrutura trilaminar muito fluidica. Aproximadamente, 7 a 11 flagelos estão localizados no espaço periplásmico entre a membrana e a parede celular de B. burgdorferi (Hovind-Hougen, 1984).

\subsection{Doença de Lyme}

Primariamente, a doença de Lyme é uma enfermidade infecciosa causada por Borrelia burgdorferi (sensu lato), transmitida pela picada de carrapatos do gênero Ixodes (Sigal, 1995; Marconi et al., 1995). Tem sido estabelecido que a doença de Lyme é causada, quando o agente etiológico é transmitido ao homem através de carrapatos predominantemente do complexo Ixodes ricinus. Entretanto, estudos recentes (Oliver Jr., 1996) demonstraram que outras espécies nåo pertencentes ao complexo $I$. ricinus, têm sido encontradas naturalmente infectadas com esta espiroqueta em diferentes regiões geográficas, tais como I. hexagonus na Europa, I. ovatus no Japão e I. uriae nos hemisférios Norte e Sul em colónias de aves marinhas. Segundo Feir et al. (1994) e Oliver Jr. (1996), as espécies de carrapatos Dermacentor variabilis, $D$. 
andersonii e Amblyomma americanum, podem também estar envolvidas na transmissão da doença no Sul dos Estados Unidos, estando associadas à $B$. burgdorferi ou ainda à espécies geneticamente heterogêneas.

Um estudo retrospectivo através de testes de Reação de Polimerase em Cadeia (PCR) foi realizado com carrapatos de coleções de museus. Surpreendentemente, um material ixodológico datado de 1946 procedente do leste de Long Island, Estados Unidos, revelou a presença de $B$. burgdorferi (Persing et al., 1990).

Alguns aspectos clínicos e epidemiológicos da borreliose de Lyme já eram conhecidos de estudiosos da Europa desde o início do século. Herxheimer \& Hartman (1902) descreveram a lesão crônica da doença de Lyme como acrodermatite crônica atrófica. Afzelius (1921) relatou a presença de eritema crônico migratório (ECM) associado à picada de carrapatos e Bannwarth (1944) associou a meningorradiculite com algum agente infeccioso transmitido por carrapatos da espécie lxodes ricinus.

O ciclo epidemiológico completo da doença de Lyme foi desvendado nos EUA, a partir da década de 1970 quando surgiram os primeiros casos de eritema crônico migratório (ECM) associados às manifestações articulares semelhantes à doença reumatóide juvenil na comunidade de Lyme (Connecticut), cujos doentes haviam sido picados por carrapatos Ixodes scapularis (=1. dammini) (Steere et al., 1978, Steere \& Malawista, 1979).

Inicialmente, o agente etiológico foi isolado por Barbour e Burgdorfer (Barbour, 1984), nos espécimens capturados. Posteriormente, a espiroqueta foi isolada no sangue, articulação, liquor e pele de portadores desta enfermidade (Steere et al., 1984). Em homenagem a Burgdorfer, o agente etiológico recebeu o nome de Borrelia burgdorferi.

O aspecto clínico da doença em humanos, é uma condiçăo inflamatória aguda ou crônica envolvendo um multiestágio e um multissistema comprometendo pele, coração, articulação e sistema nervoso central ou periférico (Steere, 1989). 
A persistência da infeç̧ão em humanos é desconhecida, embora a espiroqueta tenha sido isolada de pele, líquido cerebro-espinhal, líquido sinovial e miocárdio, meses e até anos após o início dos sintomas (Asbrink \& Hovmark, 1988).

As caracteristicas clínicas da doença de Lyme variam conforme 0 continente geográfico, e admite-se que esta resposta heterogênea decorra da existência de cepas distintas de Borrelia burgdorferi (sensu lato) elou de espécies diferentes (Marconi et al., 1995), explicando a necessidade da realização de ensaios sorológicos (ELISA ou Western-blotting), com antígenos adequados para cada área geográfica.

Assim, predomina nos EUA a lesão cutânea aguda e a artrite, enquanto que na Europa ocorre o predomínio de complicações neurológicas.

\subsubsection{Ciclo epidemiológico e enzoótico da doença de Lyme}

Nos paises onde a doença é endêmica, os veados e roedores são os reservatórios naturais. Trata-se pois, de uma zoonose silvestre, onde o homem e os animais domésticos se contagiam quando adentram ao ecossistema composto de florestas e animais silvestres (Magnarelli et al., 1986).

Desde a primeira descrição há duas décadas a doença tem se espalhado no mundo com focos endêmicos distribuídos na América do Norte, Europa e Norte da Ásia, tornando-se um grande problema de Saúde Pública. Porém, a epidemiologia e a ecologia da borreliose de Lyme são bastante complexas, existindo muitos pontos que não estão esclarecidos (Dennis, 1993).

As análises de reação da polimerase em cadeia (PCR) revelaram distinçăo para diversos isolados de Borrelia burgdorferi (sensu lato), subdividindo-a em grupos geneticamente heterogèneos: B.burgdorferi, B. garinii, B. afzelii, B. japonica, B. andersonii (Marconi et al., 1995; Oliver Jr., 1996).

A transmissão do agente etiológico, depende do tempo de contato do vetor com o hospedeiro e para ocorrer a infecção é necessário no mínimo 24 horas de contato entre vetor e hospedeiro (Piesman et al., 1987, Costello et al., 
1989). Entretanto, Angelov (1996) relatou 2 casos de doença de Lyme na Bulgária, dos quais um dos pacientes adquiriu a enfermidade em menos de 24 horas de contato com o parasito e o outro paciente, contaminou-se quando 0 conteúdo intestinal de carrapato entrou em contato com sua conjuntiva.

A porta de entrada mais importante do agente etiológico é a pele, no local onde ocorre a picada do carrapato. Há portanto, a necessidade de rigorosa inspeção na busca e remoção precoce dos carrapatos, na tentativa de prevenir o contágio.

No hemisfério Norte, as pessoas contraem a doença de Lyme principalmente através das ninfas infectadas, geralmente no final da primavera e inicio do verão. Menos freqüentemente de carrapatos adultos que normalmente se alimentam e caem no inverno e início da primavera. A espiroqueta não é transmissivel de pessoa a pessoa, excetuando em raros casos em que a borrelia atravessa a placenta e infecta o feto (Markowitz et al., 1986).

O ciclo endêmico da B.burgdorferi varia entre as localidades geográficas. No nordeste e centroeste dos Estados Unidos, larvas e ninfas de I. scapularis têm preferência em parasitar o roedor Peromyscus leucopus. Segundo Oliver Jr. (1996), estes roedores são reservatórios extremamente competentes, permanecendo infectivos durante toda a vida. O hospedeiro preferencial para os carrapatos adultos é o veado Odocoileus virginianus que não apresenta importância no ciclo biológico da espiroqueta, por ser considerado incompetente como reservatório (Telford et al., 1988) ou marginalmente competente (Oliver Jr. et al., 1992). Porém a competência pode ser relativa e necessita ser reavaliada (Randolph et al., 1996), considerando a probabilidade de infecção via nãosistêmica.

O ciclo endêmico no oeste dos Estados Unidos já é totalmente diferente. Nesta área, as borrelias mantêm-se na natureza num ciclo horizontal entre o roedor silvestre Neotoma fuscipes e o carrapato Ixodes neotomae. Somente poucas larvas e ninfas de I.pacificus alimentam-se em roedores, sendo que a maioria prefere lagartos, os quais são considerados profiláticos por não serem 
reservatórios em algumas áreas. Por esta razão, cerca de $1 \%$ das ninfas de $I$. pacificus encontram-se infectadas e a transmissão para humanos é rara, enquanto que as taxas de infecção para l. scapularis, na região nordeste americana, atingem 20 a $50 \%$ (Lane et al., 1991).

O ciclo enzoótico de $B$. burgdorferi na América do Norte foi detalhado por Dennis (1993) como: 1) Pequenos roedores servem como reservatórios comuns da infecção para os carrapatos vetores; 2) Em um ciclo de dois anos, ocorrem três estágios no ciclo biológico do carrapato vetor. Cada estágio normalmente requer apenas um simples repasto sangüíneo; 3) O ciclo de infecção é mantido transovarianamente de adulto para as larvas através dos ovos $\theta$, transestadialmente na mudança de larva para ninfa e desta para adulto; 4) A eficiência do ciclo é favorecida pelo modelo de alimentação no qual, as ninfas alimentando-se na primavera infectam os roedores que então, servem como uma fonte de infecção para as larvas que por sua vez, alimentam-se durante o verão; 5) Os veados, especialmente Odocoileus virginianus e outros animais silvestres de médio porte, servem como hospedeiros de carrapatos adultos que neles realizam o acasalamento e após o repasto sangüineo, as fêmeas caem ao solo para a produção de ovos.

No sul dos Estados Unidos, o ciclo enzótico é bem mais complexo, porque os carrapatos alimentam-se em uma variedade maior de hospedeiros, incluindo algumas espécies de aves incriminadas como reservatórios de borrelias. Na Europa, entretanto, muitas espécies de aves não desempenham papel como reservatórios na transmissão da borrelia, porém, atuam como disseminadoras de carrapatos em novas localidades (Matuschka \& Spielman, 1992) favorecendo novos focos de borreliose.

A espécie I. affinis estreitamente relacionada ao complexo 1 . ricinus, é encontrada naturalmente infectada no sul da América do Norte. Apesar de habitualmente não picar o homem, pode, experimentalmente, transmitir a espiroqueta. Segundo Oliver Jr. (1996), é provavel que esta espécie participe do 
ciclo enzoótico no sul dos Estados Unidos e também, em outras áreas dentro do seu limite de distribuição.

\subsubsection{Distribuição Global}

A doença de Lyme tem distribuiçăo geográfica cosmopolita. Vários casos foram registrados nas regiōes Neártica e Paleártica. As área endêmicas na Europa incluem as llhas Britânicas, Escandinávia, Alemanha, Áustria, Suécia e - Oeste Europeu. Na União Soviética, a área central é afetada desde o Mar Báltico até o Oceano Pacífico (Dennis, 1993; Steere, 1994).

Uma borrelia com características distintas de B. burgdorferi foi detectada em carrapatos das espécies Ixodes holocyclus e Haemaphysalis longicornis procedentes de regióes afetadas com doença de Lyme na Austrália (Wills \& Barry, 1991). Apesar dos relatos de casos, ainda não se tem confirmação de isolados de B. burgdorferi na África (Schmid 1985), América do Sul (Yoshinari et al., 1997) e Austrália.

Muitos casos foram também registrados na China e Japão (Steere, 1994). Sob condições de laboratório, Nakao \& Miyamoto (1994) estudaram a susceptibilidade de carrapatos das espécies I. persulcatus e l. ovatus para espiroquetas isoladas de pessoas doentes, sendo que a espécie I. persulcatus apresentou maior competência na transmissão da doença de Lyme no Japåo. No entanto, outras espécies de carrapatos têm sido encontradas naturalmente infectadas, como: I. turdus, I. tanuki, I. columnae (Nakao \& Miyamoto, 1993) e Haemaphysalis flava (Ishiguro et al., 1992).

Na Europa, Baranton et al. (1992) estudaram 48 isolados de Borrelia, os quais estavam associados à Doença de Lyme. Nestes isolados foram reconhecidos três grupos genotipicos: O grupo I, correspondente à Borrelia burgdorferi, "sensu stricto" que incluiu 28 isolados da Europa e dos Estados Unidos; o grupo II, correspondente à Borrelia garinii sp. n., onde foram incluídos 13 isolados da Europa e do Japão e o grupo III, correspondente ao grupo $B$. afzelii (=VS 461), que incluiu sete isolados da Europa e do Japão. 
A Borrelia japonica foi isolada de aves marinhas e pequenos mamiferos no Japão, porém não existem registros desta espécie causar doença em humanos (Marconi et al., 1995).

O vetor europeu mais importante é lxodes ricinus, ectoparasito tanto de aves como de mamiferos silvestres e domésticos, incluindo roedores sinantrópicos, os quais prontamente se infectam com B. afzelii, como foi observado por Matuschka et al. (1997), em estudos experimentais com Rattus norvegicus e $R$. rattus.

\subsubsection{Situaçăo da doença de Lyme no Brasil}

Yoshinari et al. (1989), publicaram o primeiro artigo alertando sobre a possibilidade da existéncia da enfermidade de Lyme no Brasil. Neste mesmo ano, uma equipe multidisciplinar, liderada pelos pesquisadores Natalino Yoshinari - FMUSP, Domingos Baggio "in memorian" e Paulo Yassuda ICBUSP, criou um laboratório objetivando a realização de sorologias (ELISA e Western-blotting), cultura de Borrelia burgdorferi (meio BSK) e a produção de antigenos a partir de B. burgdorferi (cepa americana), isolada de Ixodes dammini (isolado G 39/40, cedida pelo Dr. Allen C. Steere, Boston, USA).

Como consequiência, na região de ltapevi, SP, foram identificados os primeiros casos clínicos com confirmação sorológica que apresentavam a lesão cutànea característica (ECM) e manifestações sistêmicas compativeis (Yoshinari et al., 1992, Barros et al., 1993, Yoshinari et al., 1993 a, b, c, d, 1995). Outros casos foram relatados no Rio de Janeiro (Azulay et al., 1991) e em Manaus (Talhari et al., 1992), porém, exclusivamente com manifestações cutâneas.

Embora a sorologia dos pacientes examinados fosse positiva, os titulos detectados levaram os pesquisadores da USP à suposição de estarem frente a uma cepa de $B$. burgdorferi diferente da americana ou ainda de uma outra espécie.

Em sangue de bovinos procedentes de uma propriedade rural no município de Bragança Paulista, SP, algumas espiroquetas do gênero Borrelia 
foram visualizadas em esfregaços sangüineos corados com Giemsa (Benesi et al., 1995). Os autores realizaram sorologia para doença de Lyme e verificaram que $23.8 \%$ dos soros bovinos analisados estavam positivos, tendo um animal desenvolvido artrite e três funcionários com lesões cutâneas semelhante ao eritema migratório.

Fonseca et al. (1995) observaram borrelias em sangue e urina de gambás procedentes de Itaguaí, RJ $\theta$ os exames sorológicos preliminares realizados nos animais revelaram alta freqüência de soropositivos. Igualmente, a sorologia em bovinos desta mesma região mostrou alta reatividade de anticorpos da classe IgG (75.2\%) contra antígenos da cepa B.burgdorferi $G$ $39 / 40$.

Os exames sorológicos efetuados rotineiramente no Laboratório de Investigação em Doença de Lyme da Faculdade de Medicina da USP, continuam a mostrar títulos de anticorpos muito baixos que desaparecem rapidamente. Estes achados levam a crer que o agente etiológico brasileiro seja diferente do americano empregado no ensaio sorológico. Desta forma, o encontro do agente etiológico autóctone e o seu isolamento torna-se imprescindivel para a realização de um exame sorológico diagnóstico mais sensivel.

Portanto a sorologia para doença de Lyme no Brasil deve ser interpretada criteriosamente e o isolamento do agente está a requerer maiores investigaçỏes (Yoshinari et al., 1995).

Paralelamente aos ensaios sorológicos, a realização de culturas de sangue de portadores da doença de Lyme tem sido procedimento de rotina. Em uma destas culturas foi observado a presença de espiroquetas do gènero Borrelia (Yoshinari et al., 1995, 1997).

A identificação de 4 pacientes portadores de borreliose de Lyme nas regiões de Cotia e Itapevi, SP, sugeriu a realização de um inquérito sorológico, com amostras de 1067 soros de habitantes locais. A presença de anticorpos contra B.burgdorferi (cepa G 39/40), revelou-se em $7.3 \%$ dos soros testados. 
Destes, foram excluídos 5 soros positivos para sífilis (VDRL e FTA a,b) e 11 soros positivos para leptospirose. Mesmo assim, a prevalência obtida foi de $5.8 \%$ valor este, observado para as áreas endêmicas de doença de Lyme, sugerindo contato prévio da população com o agente etiológico (Yoshinari et al., 1995).

Na região de Itapevi, SP, onde surgiram os primeiros casos de doença Lyme, foi realizado um plano piloto, de Setembro/1993 a Agosto/1994, objetivando investigar a presença de pequenos mamíferos e carrapatos nas áreas peridomiciliares. Em 12 fases de coletas foram capturados 40 mamiferos, dos quais, $25 \%$ estavam parasitados com carrapatos pertencentes aos gêneros Ixodes (76\%) e Amblyomma (24\%), (Barros-Battesti et al., 1995).

Tendo em vista estes achados, Joppert (1995) padronizou o teste ELISA para deteç̧ăo de anticorpos da classe IgG em cães domésticos de Cotia e Itapevi através da imunizaçăo de um cão com B. burgdorferi (cepa G 39/40) inativada pelo calor, com a finalidade de verificar a frequéncia de animais com sorologia positiva. Este estudo demonstrou positividade em 23 das 237 amostras de soro canino analisadas, representando uma freqüência de $9.7 \%$. Dos cães soropositivos, $70 \%$ haviam mantido contato prévio com carrapatos enquanto que $30 \%$ năo entraram previamente em contato com ixodídeos.

Todos estes resultados em conjunto, foram pois, sugestivos da presença de borrelias nestas regiões, bem como a participação de carrapatos no mecanismo de transmissão. 


\section{HIPÓTESE}

Partindo do pressuposto que, os agentes etiológicos da borreliose humana, tanto nos Estados Unidos como Europa e Ásia, realizam seu ciclo principalmente em pequenos mamíferos silvestres e, já havendo indícios de que, no Brasil, hospedeiros de lxodes spp. são preferencialmente pequenos mamiferos, é justificável a escolha destes animais para as investigações preliminares. Conseqüentemente, a hipótese a ser testada é de que marsupiais e roedores silvestres tomam parte na estrutura zoonótica do agente etiológico, de modo a ser determinante de exposição do homem à doença. 


\section{OBJETIVOS}

\section{III.1. Objetivo Geral}

Com a finalidade de contribuir para elucidar os aspectos da transmissão da borreliose, nossa pretensão foi estudar focos naturais de espiroquetas em áreas onde foram registrados casos humanos com quadro clínico e sorológico positivos, compativeis com a doença de Lyme.

\section{III.2. Objetivos Especificos}

- Estudar a fauna ixodológica de pequenos mamíferos silvestres e suas relações com os hospedeiros.

- Avaliar a importáncia das variáveis meteorológicas na distribuiçăo mensal e sazonal dos mamíferos e carrapatos, observando as relaçóes ectoparasito/hospedeiro.

- Verificar a ocorrência de infecção natural por espiroquetas nos pequenos mamiferos capturados e recapturados e nos carrapatos coletados, procurando avaliar as perspectivas de transmissão sazonal.

- Avaliar a situação de risco para infeç̧ão em humanos. 


\section{MATERIAL E MÉTODOS}

\section{IV.1. Área de estudo}

Com uma população estimada em 220.000 habitantes, o Município de Itapevi, 23032'45" S e 46056"05" W, compreende região de Mata Atlântica com vários trechos alterados pela influência antrópica caracterizada por áreas de cultivo, pastagem e edificação, formando um mosaico com vários corredores interligando às áreas com vegetação.

O Planalto Paulistano, onde está localizado o Municipio de Itapevi, SP, corresponde a uma área de $5000 \mathrm{~km}^{2}$ com altitudes entre 715 a $900 \mathrm{~m}$ (Ponçano et al., 1981). Segundo a classificaçăo de Köppen, o clima é do tipo Cwb (mesotérmico com inverno seco e verăo fresco) com precipitação anual entre 1300 a $1500 \mathrm{~mm}^{3}$ e temperatura média anual entre $20^{\circ} \mathrm{C}$ e $22^{\circ} \mathrm{C}$ (Setzer, 1949).

A área de estudo abrangeu um condomínio residencial situado a sudoeste de Itapevi, com 124.58 ha, sendo 62.07 ha de áreas loteadas com 209 residências construídas até dezembro/1994 e 32.80 ha de áreas verdes de proteção às nascentes e mananciais, cuja vegetação, é caracterizada como mata secundária em estágios de regeneraçāo (Figura 1).

Esta área foi dividida em quadrados iguais de $4000 \mathrm{~m}^{2}$, sendo selecionados um ou mais quadrados (pontos de coleta), utilizando a tabela de números aleatórios de Pereira \& Bussab (1985), para amostrar randomicamente o número mensal de captura de pequenos mamíferos silvestres e carrapatos em cada fase de campo.

A Figura 2 representa uma planta esquemática da área de estudo, composta por áreas construídas (209 residências até Dezembro/1994), áreas de loteamento com cobertura vegetal, áreas verdes de proteção às nascentes e mananciais, bem como os pontos de coletas, numerados de 1 a 18 , equivalentes aos 12 meses do ano de 1995 e aos seis primeiros meses de 1996. 


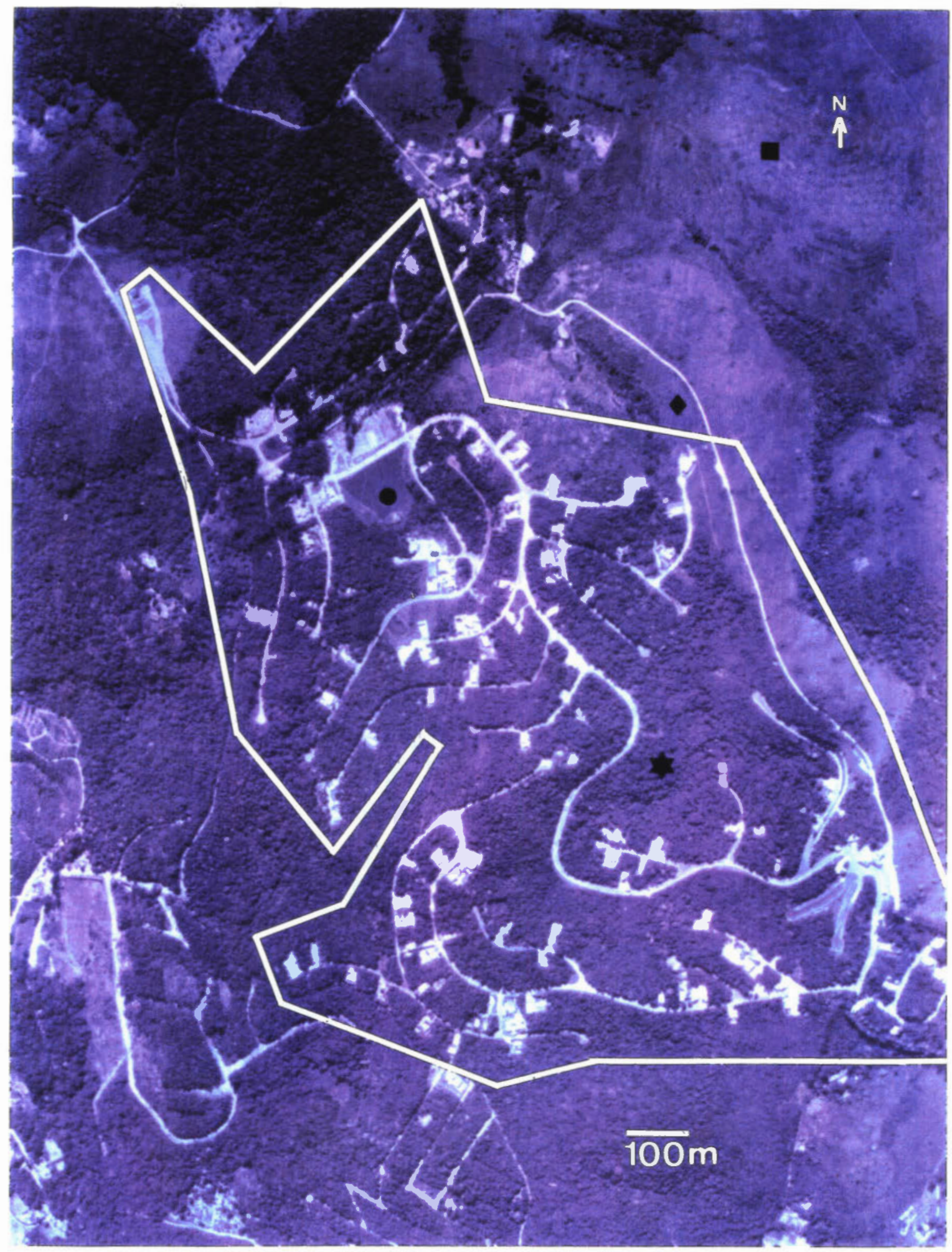

Figura 1. Fotografia aérea do condomínio residencial Transurb, Município de Itapevi, SP, em 1995. * Área de proteção às nascentes, - área cultivada, - área de pastagem, lago alimentado pelas nascentes. 


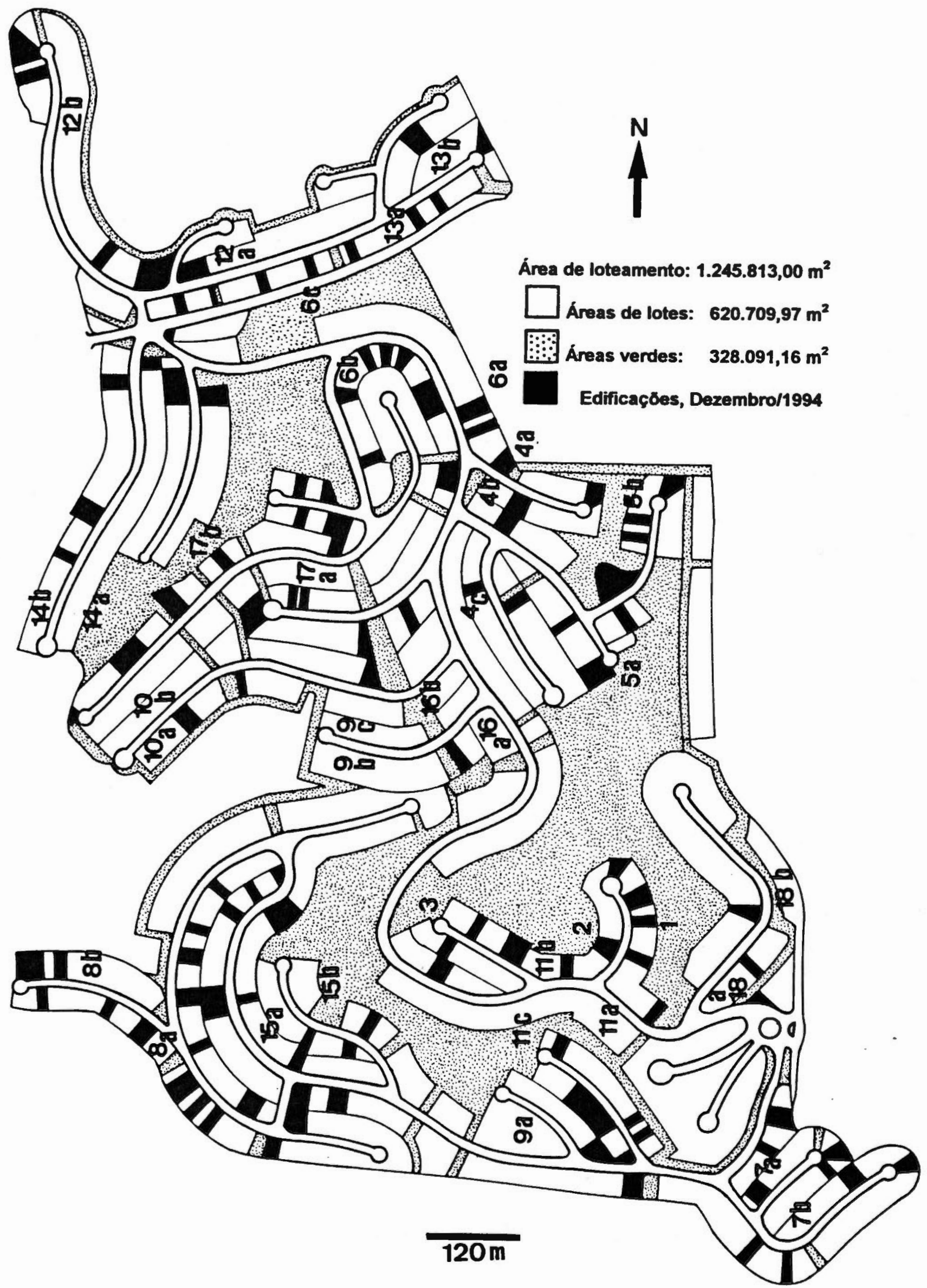

Figura 2. Planta esquemática do condominio residencial Transurb, Itapevi, SP. Os pontos de coletas numerados de 1 a 18 , correspondem aos 12 meses do ano de 1995 e aos seis primeiros meses de 1996. 


\section{IV.2. Coleta de Material - Identificaçăo hospedeiro/ parasito}

O estudo foi desenvolvido de janeiro de 1995 a junho de 1996, em coletas mensais durante 5 dias consecutivos, sempre na última semana de cada mês. Para as capturas dos marsupiais foram usadas em média 15 armadilhas do tipo "live trap" medindo $20 \times 20 \times 40 \mathrm{~cm}$, com malha de $1 \mathrm{~cm}^{2}$, distando 8 a 10 metros uma das outras. Para roedores foram usadas armadilhas medindo $10 \times 10 \times 22 \mathrm{~cm}$, com malha de $1 / 2 \mathrm{~cm}^{2}$, iniciando, nos sete primeiros meses com 12 armadilhas e posteriormente com 27, eqüidistantes 5 metros.

Mensalmente, as armadilhas foram dispostas linearmente no extrato inferior em transectos definidos dentro dos quadrados selecionados randomicamente. Nestes quadrados, as coletas de marsupiais foram realizadas em ambientes peridomiciliares nas matas das áreas verdes e de loteamento; as de roedores, em bordas de mata e em locais de primeiro estágio de regeneraçăo sucessional. O número de fileiras e a distância entre as armadilhas foram estipuladas, em função da área escolhida e do número de armadilhas disponiveis, estabelecendo-se assim os pontos de coletas. O local de cada armadilha foi, ainda, marcado com uma fita colorida indicando sua posição. As iscas utilizadas foram bacon e milho para marsupiais e roedores, respectivamente.

Diariamente todas as armadilhas foram vistoriadas. Aquelas contendo mamiferos, foram colocadas em sacos plásticos para anestesia com éter etílico. Após anestesia, o animal foi penteado sobre uma cuba branca. Os carrapatos fixos na pele, foram removidos com pinça, depositados em frascos de vidro com tampa de tecido e transportados para o laboratório para serem identificados, fotografados em microscópio estereoscópico e processados.

Depois da coleta de ectoparasitos, os marsupiais foram identificados, pesados, sexados e tomadas as suas medidas biométricas (cauda, corpo, altura da orelha direita, pata direita posterior). À seguir, foram marcados com coleira plástica, com trava, contendo um número de identificação. As condições 
reprodutivas foram observadas em fêmeas adultas, verificando-se o tamanho do marsúpio, lactação e presença de filhotes.

Ao final de cada fase de campo, os marsupiais foram fotografados e devolvidos ao ambiente, garantindo assim, através das recapturas, a possibilidade de avaliar seu contato com o agente etiológico e as perspectivas de evidências de transmissão sazonal. Todos os roedores foram fotografados, mantidos por uma semana em laboratório e, posteriormente, sacrificados.

Para a pesagem, foram usadas balança mecânica de até $5 \mathrm{~kg}$ (marsupiais) e balança eletrônica digital, modelo BCM 1100, marca Acatec, de até $500 \mathrm{~g}$. e precisão de $0.01 \mathrm{~g}$ (roedores). As medidas biométricas dos animais foram realizadas, utilizando-se régua de metal e paquímetro.

Para determinação da idade nos marsupiais, considerou-se padrões de peso e tamanho. Nos roedores, foram observados ainda, os desgastes dos molares superiores, bem como as suturas dos ossos da caixa craniana (Langguth, 1963; Kravetz ,1972) para determinação de classes etárias.

A identificação taxonômica dos mamiferos foi realizada com o auxílio do atlas de cores da pelagem de Villalobos-Dominguez \& Villalobos (1947), lista de roedores do Estado de São Paulo (Vieira, 1953; Vieira, 1955), clássicos de sistemática de mamíferos (Honacki et al., 1982; Emons \& Feer, 1990; Hershkovitz, 1992) e alguns aspectos de ecologia (Zotz, 1985).

Os roedores foram taxidermizados segundo técnicas convencionais conforme Nagorsen \& Peterson (1980). As peles e crânios foram depositadas na coleção de mastozoologia do Museu de História Natural "Capão da Imbuia", Departamento de Zoológico da Prefeitura Municipal de Curitiba, Paraná.

Os carrapatos adultos foram identificados taxonomicamente com auxilio das chaves descritas por Mendez-Arocha \& Ortiz (1958), Aragão \& Fonseca (1961), Fairchild et al. (1966) e Jones et al. (1972).

As fases imaturas de carrapatos foram fotografadas em microscópio estereoscópico e identificadas ao nivel de género, uma vez que, para a identificaçăo de larvas e ninfas ao nivel de espécie, seria necessário a 
preparação dos exemplares através de técnicas de fixação, clarificação e montagem em lâminas, bem como, um estudo especializado de quetotaxia. Porém, isto impossibilitaria a utilização dos exemplares para a preparação em meio de cultura BSK.

IV.3. Processamento do Meio de cultura de BSK Kelly-StoennerBarbour (Barbour, 1984)

1. $100 \mathrm{ml}$ de CMRL 1066 com glutamina $+500 \mathrm{ml}$ de água destilada.

2. Autoclavar por $15,300 \mathrm{ml}$ de gelatina à $5.7 \%$. Guardar para etapa 9 .

3. Aquecer $300 \mathrm{ml}$ de água destilada entre $50{ }^{\circ} \mathrm{C}$ a $70^{\circ} \mathrm{C}$ e acrescentar $5 \mathrm{~g}$ de Neopeptone (Difco), 12g Triptone (Difco), $1 \mathrm{~g}$ Yeostolate (Difco). Acrescentar à etapa 1.

4. Acrescentar à etapa 1:

$6 \mathrm{~g}$ tampão Hepes $+0.7 \mathrm{~g}$ citrato de sódio $+5 \mathrm{~g}$ glicose alfa $\mathrm{D}++0.8 \mathrm{~g}$ piruvato de sódio $+0.4 \mathrm{~g} \mathrm{~N}$-acetil glucosamina $+0.2 \mathrm{~g}$ bicarbonato de sódio $+0.3 \mathrm{~g}$ $\mathrm{MgCl} 6 \mathrm{H}_{2} \mathrm{O}$.

5. Aquecer $100 \mathrm{ml}$ de soro de coelho (Gibco) à $37{ }^{\circ} \mathrm{C}$ e depois filtrar em Whatman \# 1, filtro $0.45 \mu \mathrm{m}$ e $0.20 \mu \mathrm{m}$. Guardar para a etapa 9 .

6. Acrescentar $143 \mathrm{ml}$ de soroalbumina bovina aquecida à $37^{\circ} \mathrm{C}$ à etapa 1.

7. Ajustar o pH do meio para $7.55 \mathrm{com} \mathrm{NaOH} \mathrm{10M.}$

8. Filtrar o meio: papel de filtro Whatman \#1, filtro $0.45 \mu \mathrm{m}$ e $0.20 \mu \mathrm{m}$.

9. Combinar o meio de cultura, gelatina e o soro de coelho no Fluxo Laminar 10. Aliquotar.

\section{IV.4. Preparaçăo e análise do material biológico}

Com seringa de $1 \mathrm{ml}$ foi tirado sangue da veia caudal dos marsupiais. Algumas gotas foram colocadas imediatamente em tubo estéril Falcon contendo $6 \mathrm{ml}$ de meio de cultura (BSK) próprio para crescimento de espiroquetas do gênero Borrelia. Esfregaços em lâminas foram preparados para microscopia 
óptica (coloraçăo com Giemsa).

Os roedores capturados, foram mantidos por uma semana em caixas plásticas com maravalha e cobertas com meia de seda. Diariamente, a maravalha foi vistoriada para a coleta das fases jovens de carrapatos, que se desprenderam naturalmente quando completaram seu repasto sangüíneo. Após este periodo, os roedores foram submetidos à punção cardiaca. Algumas gotas de sangue foram inoculadas em tubo Falcon contendo $6 \mathrm{ml}$ de meio de cultura (BSK). Foram ainda, preparados esfregaços corados com Giemsa para exames de microscopia óptica.

Depois de sacrificados, os roedores foram abertos ventralmente, com bisturi estéril, em Fluxo Laminar. Imediatamente, o sexo dos roedores foi confirmado pela exposição dos órgãos sexuais. Partes da bexiga, rim, baço e fígado foram colocadas em tubos Falcon contendo $6 \mathrm{ml}$ de meio de cultura BSK e $18 \mu l$ de antibiótico Kanamicina para reduzir a contaminação. Utilizou-se o restante destes órgãos para "in print" em lâminas que foram coradas com Giemsa. A seguir, os animais foram envolvidos em papel alumínio, colocados em sacos plásticos devidamente etiquetados com o número de campo e conservados em freezer à $-70^{\circ} \mathrm{C}$, até o momento de serem taxidermizados.

Seguindo as orientaçőes de Takada et al. (1994), os ectoparasitos foram lavados com peróxido hidrogenado à $3 \%$ durante 3 minutos e mergulhados em etanol à $70 \%$, por 5 minutos. Em Fluxo Laminar, os carrapatos foram dissecados com auxílio de pinça e bisturi em placas de Petri contendo $1 \mathrm{ml}$ de meio de cultura BSK e $3 \mu l$ de antibiótico kanamicina. Os homogeneizados de órgăos internos dos espécimens adultos e os macerados totais dos jovens, foram inoculados em tubos Falcon contendo $5 \mathrm{ml}$ de meio de cultura BSK e $15 \mu \mathrm{l}$ de antibiótico kanamicina.

As culturas de sangue, órgãos dos hospedeiros e carrapatos, foram mantidas em estufa à $33^{\circ} \mathrm{C}$ por três semanas, sendo semanalmente vistoriadas em Microscópio de Campo Escuro (ME) modelo Axiolab da marca Zeizz, com aumento de $1000 \mathrm{X}$ em imersão. Aquelas culturas positivas para espiroquetas, 
foram fotografadas em ME. Foram realizados vários repiques destas culturas para manter o crescimento dos microrganismos.

Os esfregaços das culturas positivas foram preparados e corados pelo método de impregnação com prata (Fontana-Tribondeau), conforme a técnica descrita por Bier (1985). As láminas foram fotografadas em Microscópio Óptico (MO) modelo Ultraphoto II da marca Zeiss, com aumento de $1260 \mathrm{X}$. Os esfregaços sangüíneos $e$ "in print" de órgãos corados com Giemsa, foram fotografados em Microscópio Óptico (MO) modelo Axiolab da marca Zeiss, com aumento de $1000 \mathrm{X}$. Alíquotas das culturas positivas foram congeladas, com glicerol, em nitrogênio líquido para serem conservadas até o momento de serem processadas por novas técnicas.

\section{IV.5. Tratamento Estatístico}

\section{IV.5.1. Índices de densidade relativa de mamiferos e carrapatos}

Devido a variação no número de armadilhas, foi calculado o índice de densidade relativa (IDR) dos animais capturados e dos carrapatos, baseando-se em Crespo (1966) e Kravetz (1972). Para o cálculo do IDR, aplicou-se a fórmula: IDR dos mamiferos = [número de indivíduos capturados $/$ dias de coleta $x$ número médio de armadilhas] $\times 100$ e IDR dos carrapatos $=$ [número de exemplares coletados / número de dias de coleta $\times$ número de mamíferos] $\times 100$.

IV.5.2. Aplicação dos coeficientes de correlaçăo de Spearman e Pearson - Teste de Fisher e Qui-quadrado

Os números absolutos de mamíferos e carrapatos coletados, foram correlacionados com as variáveis meteorológicas de temperatura média semanal, temperatura média mensal, pluviometria média semanal, pluviometria média mensal, pluviometria acumulada semanal e pluviometria acumulada mensal. Por serem variáveis discretas (número de mamíferos e carrapatos) e variáveis contínuas (dados meteorológicos), estas correlaçőes foram obtidas 
pelo coeficiente de Spearman =rs (Siegel, 1977).

Os indices de densidade relativa de marsupiais (IDRM), roedores (IDRR) e carrapatos (IDRC), foram correlacionados com as variáveis meteorológicas através do coeficiente de correlação de Pearson $=r$ (Glass \& Stanley, 1980) uma vez que todas as variáveis são contínuas.

Ambos coeficientes de correlação variam entre 1 e -1 . Quanto mais próximo de 1 ou -1 , maior é a associação entre as variáveis; quando próximo de zero, menor é a associação entre elas. Um coeficiente igual a 1 ou -1 , indica respectivamente, associação linear perfeita direta ou inversa; um coeficiente igual a zero, indica ausência de associação linear. No entanto, a ausência de associação linear não significa que não possa existir outro tipo de associaçăo entre as medidas, por exemplo, quadrática.

O teste qui-quadrado foi aplicado para verificar se houve distribuição uniforme entre o número total de carrapatos coletados em ambas estações sazonais, bem como, para verificar se houve diferenças significativas da infestação de carrapatos segundo o sexo do hospedeiro, ao nivel de significância de $p<0.05$.

Para testar as diferenças entre as proporções de mamiferos capturados em ambas estaçōes sazonais, bem como, para verificar se houve sazonalidade entre os diferentes estágios biológicos de carrapatos, aplicou-se o teste de Fisher. Este teste não paramétrico é útil para analisar dados discretos nominais ou ordinais, quando as duas amostras independentes são pequenas (Zar, 1974; Siegel, 1977).

A prevalência mensal e os índices de infestaçăo de carrapatos adultos e imaturos por grupos de hospedeiros, foram calculados para estipular o grau de infestação mensal, segundo o estágio biológico dos carrapatos na área de estudo. Os índices de infestação parasito/hospedeiro, segundo as espécies de mamíferos, faixa etária e sexo, foram calculados para verificar a intensidade de infestação de acordo com o sexo e idade do hospedeiro. Ambos os índices, 
foram calculados através da relação do total de carrapatos coletados pelo total de animais capturados.

Para as análises estatísticas, utilizou-se o programa Stat Graf (verson 5.0, Statistical Graphics System - STSC).

Os dados pluviométricos foram fornecidos pela Companhia de Saneamento Básico do Estado de São Paulo (SABESP), estação de Morro Grande, Cotia - SP e os dados de temperatura foram obtidos no local de coleta, através de termômetro seco de máxima e mínima.

\section{IV.6. Instituiçð̃es de Apoio}

Todas as preparações do material ectoparasitológico coletado, bem como suas identificações taxonômicas e fotografias em microscópio estereoscópico, foram realizadas no Laboratório de Artrópodes do Instituto Butantan.

O processamento do meio de cultura BSK de todo o material biológico e as fotomicrografias das espiroquetas "in vivo" em campo escuro e em lâminas coradas foram realizadas no Laboratório de Investigação em Doença de Lyme da Faculdade de Medicina da USP.

Parte da microscopia em campo escuro foi realizada no Laboratório de Prática de Saúde Pública da Faculdade de Saúde Pública-USP.

A taxidermia de crânios e pele, bem como, a identificação taxonómica dos roedores, foram realizadas no Museu de História Natural Capão da Imbuia, Curitiba, PR. 


\section{RESULTADOS}

\section{V.1. Espécies de mamíferos e carrapatos - Relaçăo parasitol} hospedeiro

Em 18 meses, foram capturados 134 exemplares de pequenos mamíferos, totalizando 11 espécies. A Ordem Didelphidia ( $N=62,46.3 \%$ ), foi representada por duas Familias: Didelphidae - Didelphis marsupialis $(\mathrm{N}=61$; $98.4 \%$ ) e Marmosidae - Marmosops incanus ( $\mathrm{N}=1 ; 1.6 \%$ ). A Ordem Rodentia $(\mathrm{N}=72,53.7 \%)$, foi representada por nove espécies de três Familias: Muridae (95.8\%) - Akodon cursor ( $\mathrm{N}=30 ; 41.6 \%)$, Bolomys lasiurus $(\mathrm{N}=13 ; 18.1 \%)$, Oligoryzomys nigripes ( $N=13 ; 18.1 \%)$, Oxymycterus hispidus ( $N=6 ; 8.3 \%)$, Oxymycterus nasutus $(\mathrm{N}=5 ; 6.9 \%)$, Oryzomys ratticeps $(\mathrm{N}=1 ; 1.4 \%)$ e Rattus norvegicus ( $\mathrm{N}=1 ; 1.4 \%)$; Echimyidae (2.8\%) - Euryzygomatomys spinosus $(\mathrm{N}=2$; $2.8 \%$ ) e Caviidae (1.4\%) - Cavia aperea ( $N=1 ; 1.4 \%)$. O esforço de captura foi de 2888 armadilhas/noite (número total de armadilhas utilizadas durante os 18 meses) resultando num sucesso de captura de $4.6 \%$ na área amostrada, com uma média mensal de 7.4 indivíduos capturados por mês.

Um total de 88 carrapatos, sendo $\mathrm{N}=87(98.9 \%)$ do género /xodes e $\mathrm{N}=1$ (1.1\%) do gênero Amblyomma, foram colhidos em 39 hospedeiros: Didelphidia $(\mathrm{N}=26,19.4 \%)$ e Rodentia $(\mathrm{N}=13,9.7 \%)$, representando $29.1 \%$ de indivíduos parasitados dentre o total de mamíferos capturados durante o período de estudo (Tabela 1).

Os carrapatos, todos da família Ixodidae, foram representados por especimens em estágios imaturos de lxodes sp. ( $N=42,47.7 \%$ ), dos quais, $20.5 \%(\mathrm{~N}=18)$ e $27.2 \%(\mathrm{~N}=24)$ eram, respectivamente larvas e ninfas (Figura 3a e b); e 52.3\% ( $\mathrm{N}=46)$ de adultos identificados como: Ixodes didelphidis Fonseca \& Aragão, 1951 (Figuras 4a e b, 5a e b), Ixodes loricatus Neumann, (Figuras 6a e b, 7a e b), Amblyomma cajennense (Fabricius, 1787) (Figura 8), cujas freqüências foram, respectivamente $21.6 \%, \mathrm{~N}=19 ; 29.5 \%, \mathrm{~N}=26$ e $1.1 \%, \mathrm{~N}=1$. 
Tabela 1. Distribuiçåo mensal de carrapatos coletados nos marsupiais e roedores capturados em Itapevi, SP, entre Janeiro/1995 e Junho/1996, segundo as estaçరes do ano.

\begin{tabular}{|c|c|c|c|c|c|c|c|c|c|c|c|c|}
\hline \multirow[b]{4}{*}{ Estaçסes } & & & \multicolumn{6}{|c|}{ Carrapatos em marsupiais } & \multicolumn{3}{|c|}{ Carrapatos em roedores } & \multirow[b]{4}{*}{ TOTAL } \\
\hline & & & & & Ixodes & & Amblyomma & & Ixode & s sp. & & \\
\hline & \multicolumn{2}{|c|}{ Hospedeiros } & \multicolumn{2}{|c|}{ Imaturos } & \multicolumn{2}{|c|}{ Adultos } & \multirow{2}{*}{$\frac{\text { Adulto }}{\text { A.cajennense }}$} & \multirow[b]{2}{*}{ Subtotal } & \multicolumn{2}{|c|}{ Imaturos } & \multirow[b]{2}{*}{ Subtotal } & \\
\hline & Marsuplais & Roedores & Larva & Ninfa & 1.didelphiolis & I. Ioncatus & & & Larva & Ninfa & & \\
\hline Chuvosa & & & & & & & & & & & & \\
\hline $\begin{array}{l}\text { Jan/95 } \\
\text { Fev/95 }\end{array}$ & $\begin{array}{l}2(2) \\
5(2)\end{array}$ & $1(0)$ & $\begin{array}{l}- \\
-\end{array}$ & $\begin{array}{l}1 \\
-\end{array}$ & $\begin{array}{l}1 \\
2\end{array}$ & $\begin{array}{c}13 \\
-\end{array}$ & - & $\begin{array}{c}15 \\
2\end{array}$ & - & - & - & $\begin{array}{l}15 \\
2\end{array}$ \\
\hline Mart95 & $7(1)$ & $1(0)$ & - & - & 5 & - & - & 5 & - & - & - & 5 \\
\hline \multicolumn{13}{|l|}{ Seca } \\
\hline Abr/85 & $6(1)$ & $4(1)$ & - & - & 1 & - & - & 1 & 1 & - & 1 & 2 \\
\hline Mai/95 & $3(1)$ & $5(0)$ & - & - & - & 1 & - & 1 & - & - & - & 1 \\
\hline Jun/95 & $5(0)$ & $10(0)$ & - & - & - & - & - & - & - & - & - & - \\
\hline Jul/95 & $2(1)$ & $7(0)$ & 3 & - & - & - & - & 3 & - & - & - & 3 \\
\hline Ago/95 & $3(1)$ & $8(8)$ & - & - & - & 1 & - & 1 & 9 & 18 & 27 & 28 \\
\hline \multicolumn{13}{|l|}{ Chuvosa } \\
\hline Out/95 & $2(0)$ & $6(1)$ & - & - & - & - & - & - & - & 1 & 1 & 1 \\
\hline Nov/95 & $3(2)$ & $3(0)$ & - & - & - & 4 & - & 4 & - & - & - & 4 \\
\hline Dez/95 & $2(1)$ & $1(0)$ & - & - & - & 1 & - & 1 & - & - & - & 1 \\
\hline Jan/96 & $3(1)$ & $3(0)$ & - & - & 1 & - & - & 1 & - & - & - & 1 \\
\hline Fev/96 & $1(1)$ & $4(0)$ & - & - & 1 & - & - & 1 & - & - & - & 1 \\
\hline Mar/96 & $2(2)$ & - & - & - & 2 & - & 1 & 3 & - & - & - & 3 \\
\hline \multicolumn{13}{|l|}{ Seca } \\
\hline Abr/86 & $4(2)$ & $2(0)$ & 1 & 1 & 1 & 2 & - & 5 & - & - & - & 5 \\
\hline Mai/96 & $3(1)$ & $7(2)$ & - & - & 1 & - & - & 1 & 3 & - & 3 & 4 \\
\hline Jun/se & $4(3)$ & $4(0)$ & - & - & 4 & - & - & 4 & - & - & - & 4 \\
\hline TOTAL & $62(26)$ & $72(13)$ & 4 & 5 & 18 & 26 & 1 & 55 & 14 & 19 & 33 & 88 \\
\hline
\end{tabular}

Número entre parenteses 6 igual ao número de hospedeiros infestados. 


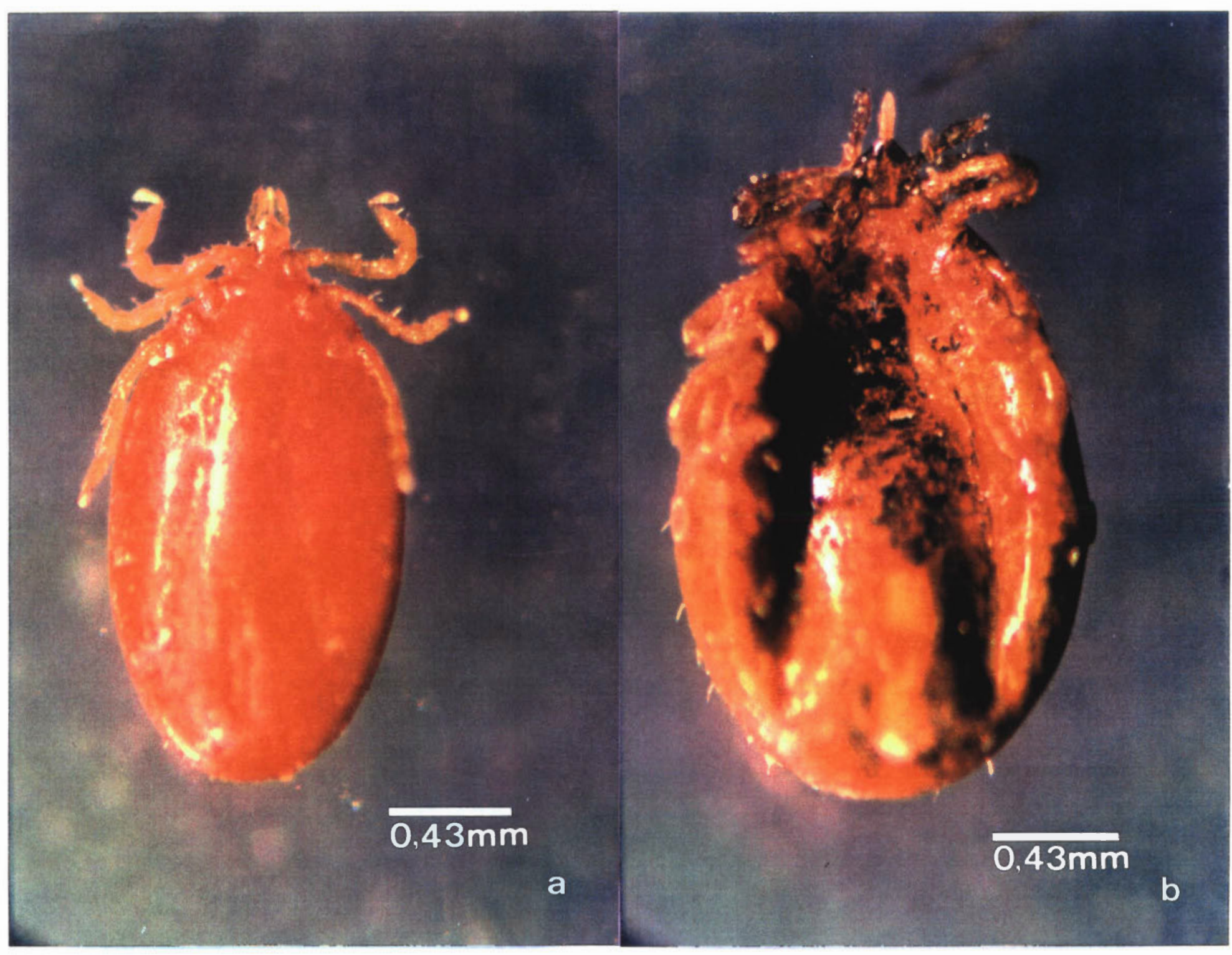

Figura 3. Carrapatos imaturos de Ixodes sp. (Ixodidae: Parasitiformes) vista ventral. a) larva (26 X); b) ninfa (26X). 


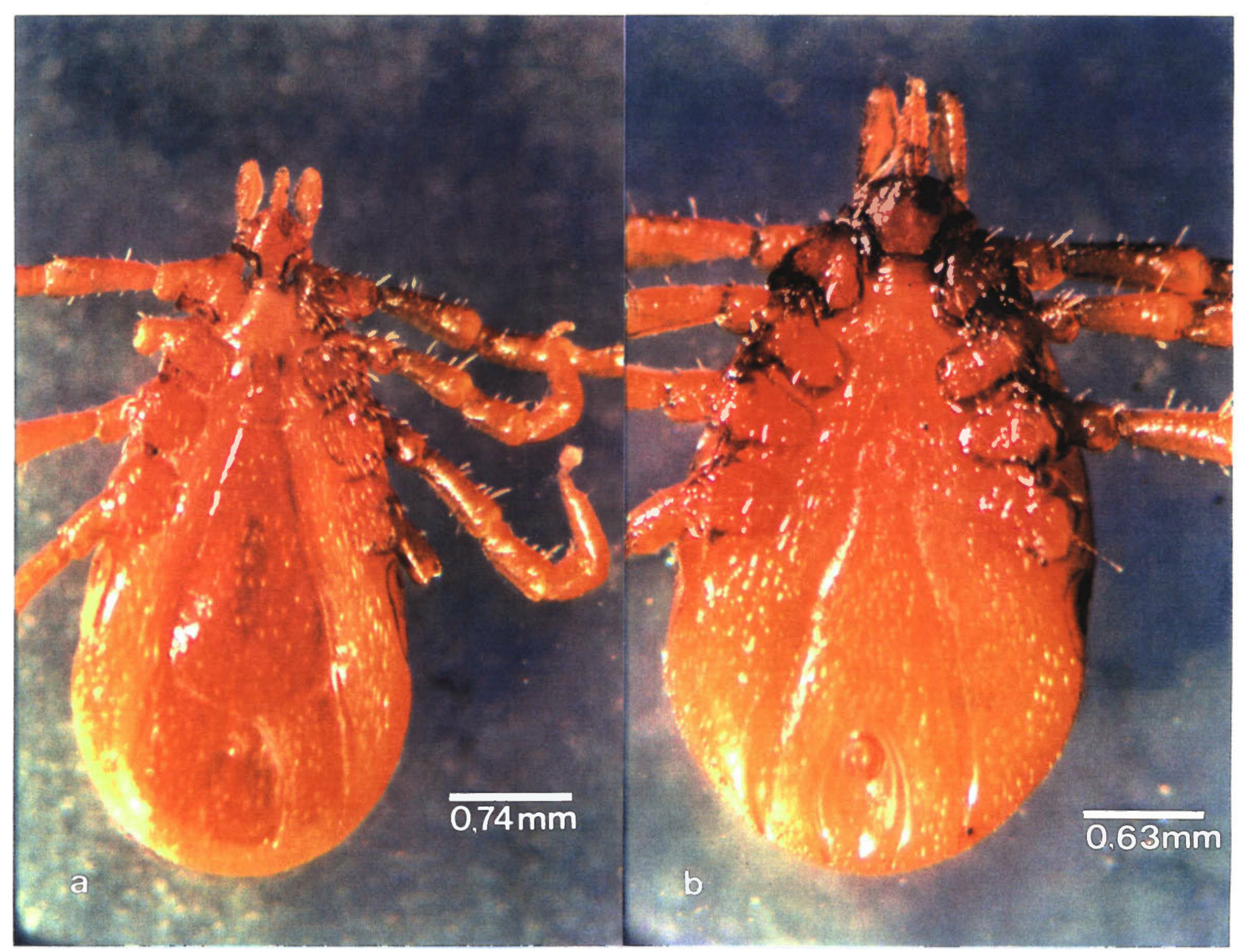

Figura 4. Ixodes dide/phidis (Ixodidae: Parasitiformes), vista ventral. a) macho adulto (15 X); b) fêmea adulta $(18 \mathrm{X})$. 


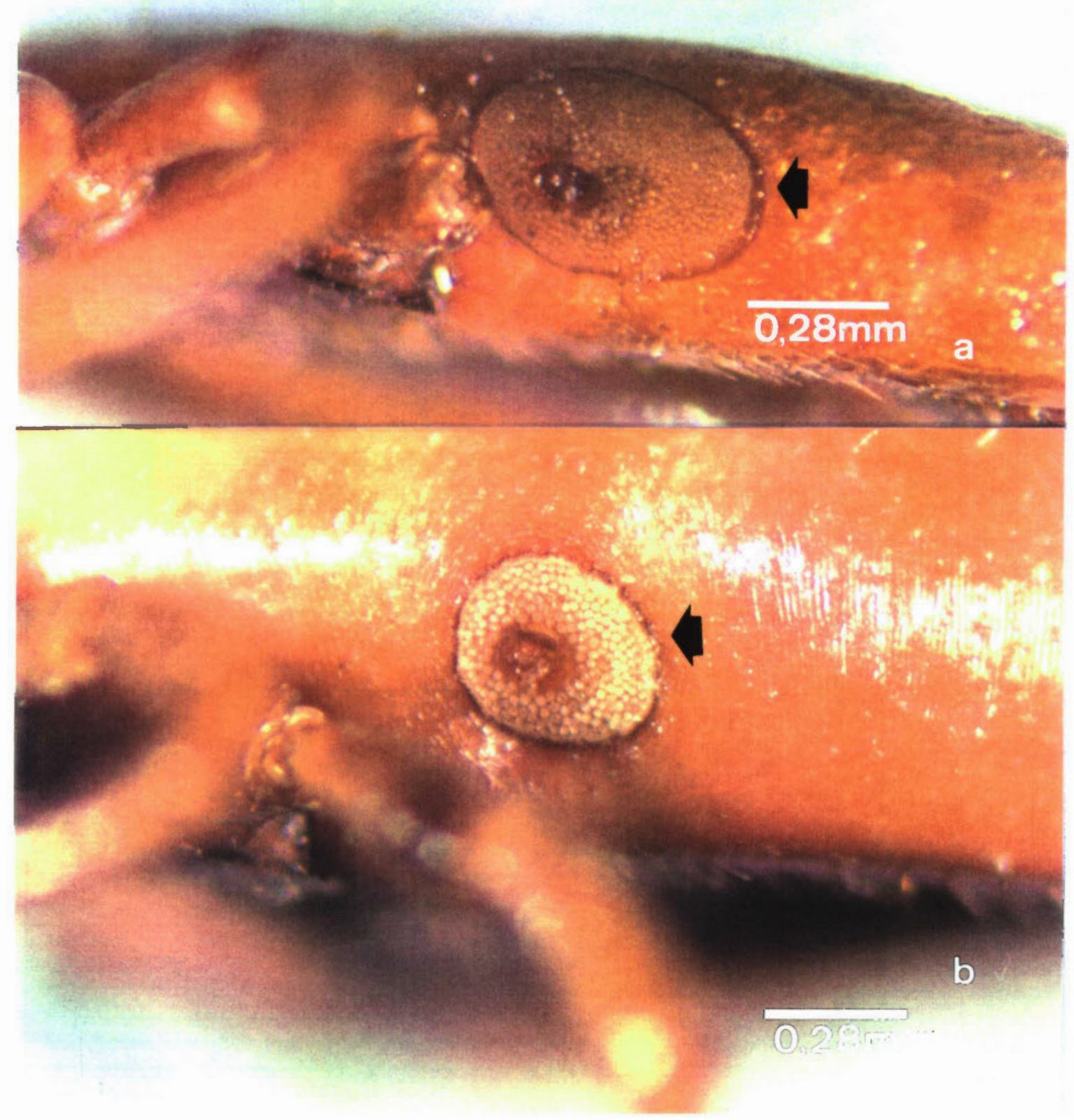

Figura 5. Placa peritremal de Ixodes didelphidis (Ixodidae: Parasitiformes) adultos, vista lateral (40 X). As setas evidenciam o bordo posterior. a) macho; b) fêmea. 

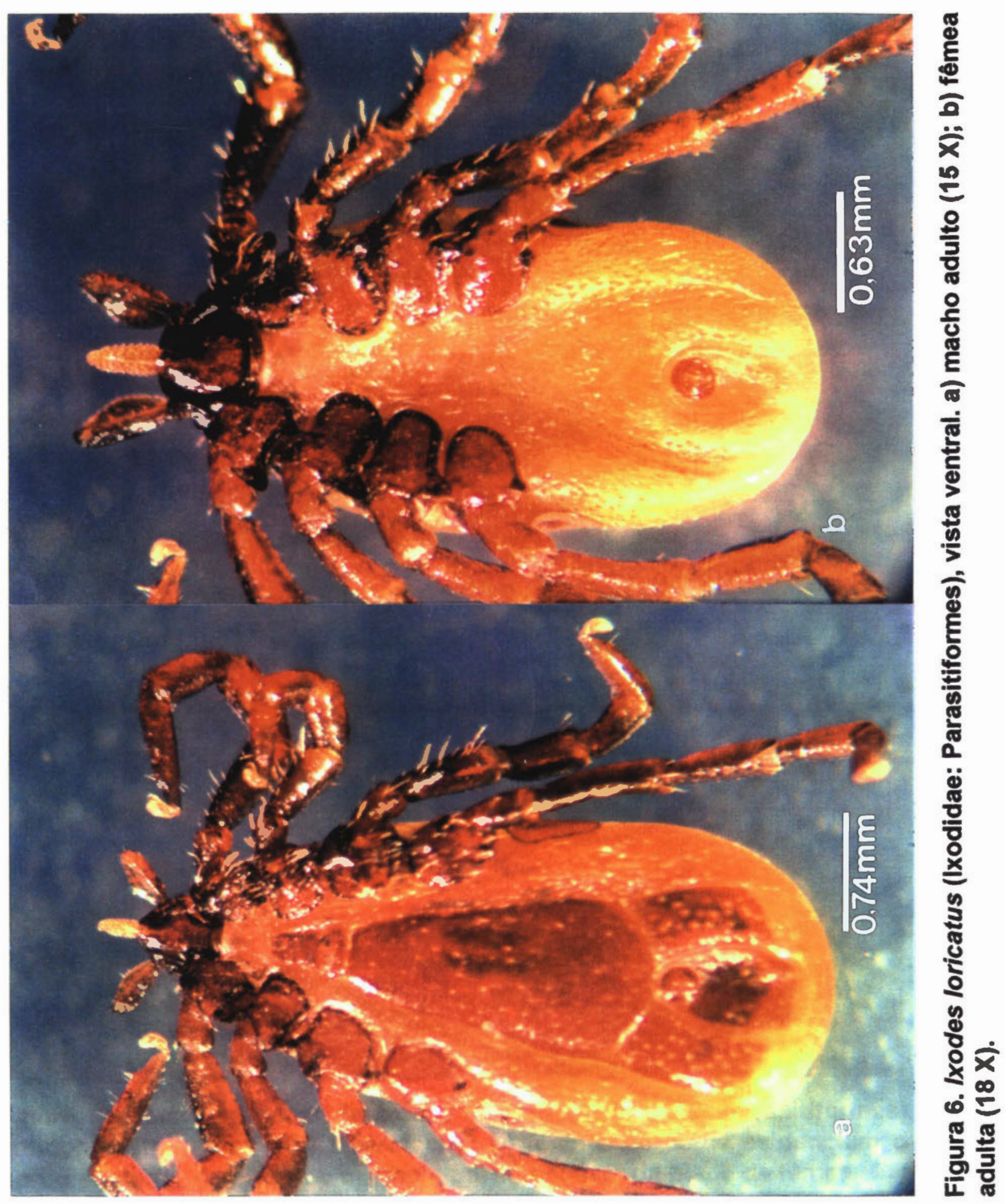

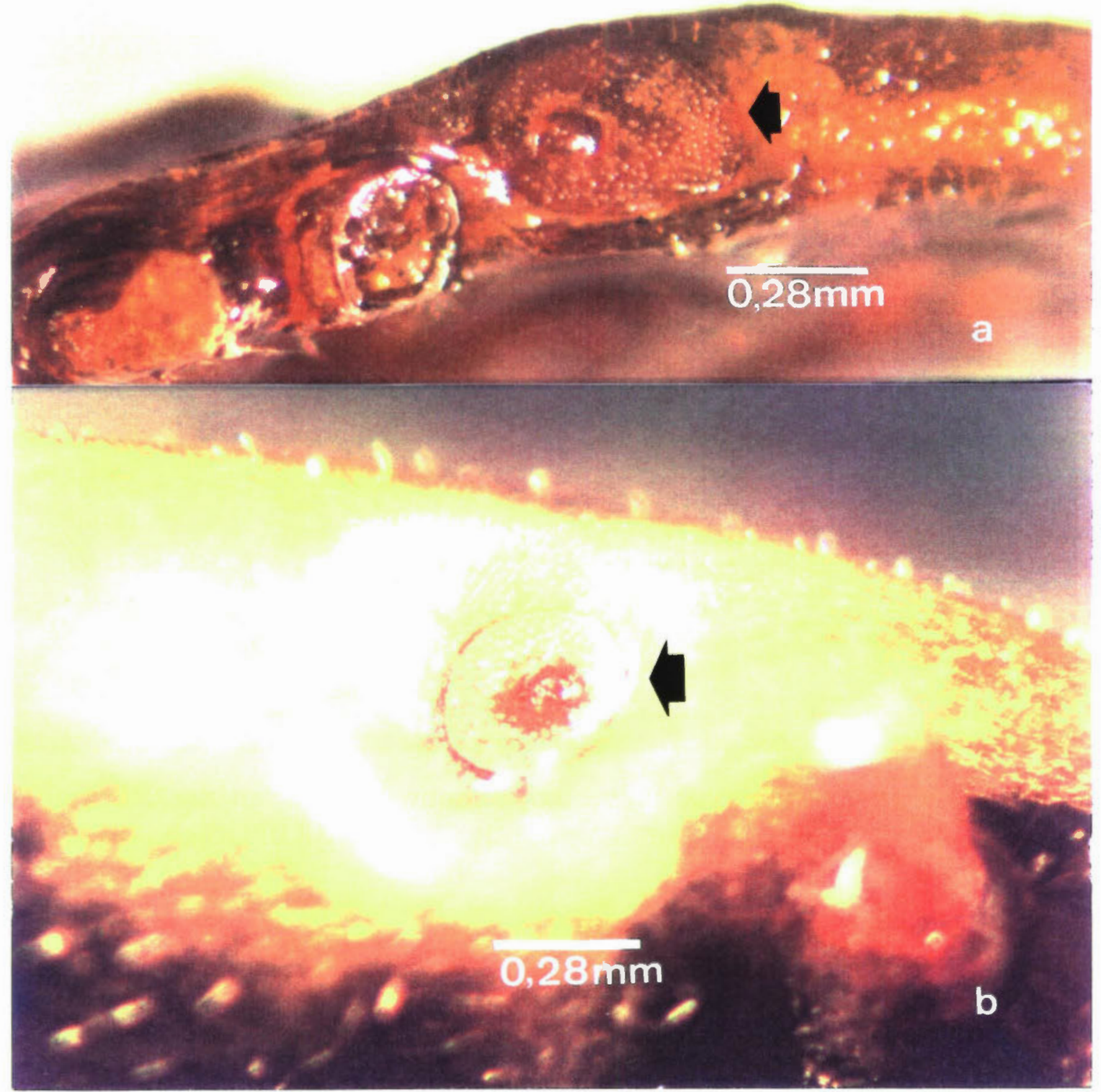

Figura 7. Placa peritremal de Ixodes loricatus (Ixodidae: Parasitiformes) adultos, vista lateral (40 X). a) macho; b) fêmea. As setas evidenciam o bordo posterior da placa do macho e bordo anterior da placa da fêmea. 


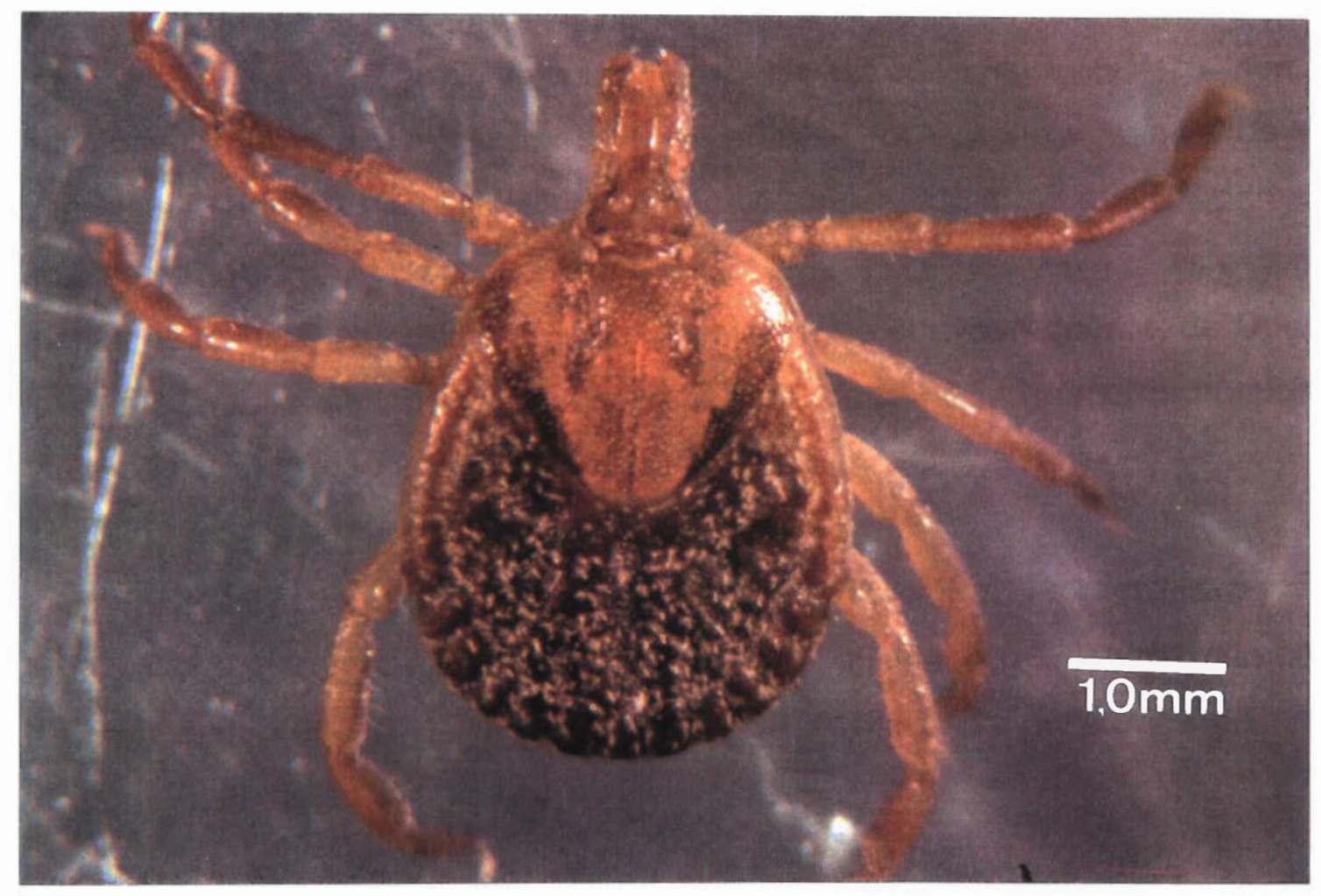

Figura 8. Amblyomma cajennense (Ixodidae: Parasitiformes), vista dorsal da fêmea adulta (10 X). 
A freqüència de parasitismo (Tabela 1) registrada entre marsupiais foi $19.4 \%$ ( $N=26)$, com infestação somente em gambás da espécie Didelphis marsupialis (Figura 9); entre roedores, a freqūência de parasitismo foi de $9.7 \%$ $(N=13)$, distribuida entre as espécies Akodon cursor, Bolomys lasiurus e Oligoryzomys nigripes, ilustrados respectivamente, nas Figuras 10, 11 e 12. Os demais mamiferos capturados $(70.9 \%)$, foram negativos para estes ectoparasitos.

A precipitação acumulada nos 12 meses de 1995 e nos 6 primeiros meses de $1996 \mathrm{foi}$, respectivamente, de $1432.40 \mathrm{~mm}^{3}$ e $684.70 \mathrm{~mm}^{3}$. A pluviometria média mensal em 1995 e em 1996 foi, respectivamente, de 4.61 $\mathrm{mm}^{3}$ e $3.77 \mathrm{~mm}^{3}$. A temperatura média nos 12 meses de 1995 e nos 6 primeiros meses de 1996 foi, respectivamente, de $21.2^{\circ} \mathrm{C}$ e $21.7^{\circ} \mathrm{C}$, com duas estações definidas: estação seca-fria, de Abril à Setembro e chuvosa-quente, de Outubro a Março. Dados semanais e mensais de temperatura e pluviometria obtidos na área de estudo estão apresentados na Tabela 2.

\section{V.1.2. Distribuiçăo mensal e sazonal de mamíferos e carrapatos}

Os números absolutos e os índices de densidade relativa de marsupiais (IDRM), roedores (IDRR) e carrapatos (IDRC) em cada ponto/més de coleta (Figura 2), estão apresentados na Tabela 3.

Para verificar se houve correlação entre os dados meteorológicos e os números absolutos e relativos de marsupiais, roedores e carrapatos coletados mensalmente, foram aplicados os coeficientes de correlação de Spearman e Pearson.

A Tabela 4 apresenta ambos os coeficientes de correlação e, entre parênteses, os niveis descritivos $(=p)$ do teste de hipótese de associação nula entre as variáveis, com as correlaçōes significativas destacadas em negrito. Um valor $p<0.05$ indica que existe associaçăo linear e p>0.05 indica ausência de associaçăo linear entre as variáveis. As correlaçōes foram inversas e significativas entre o número de roedores capturados e a temperatura e 


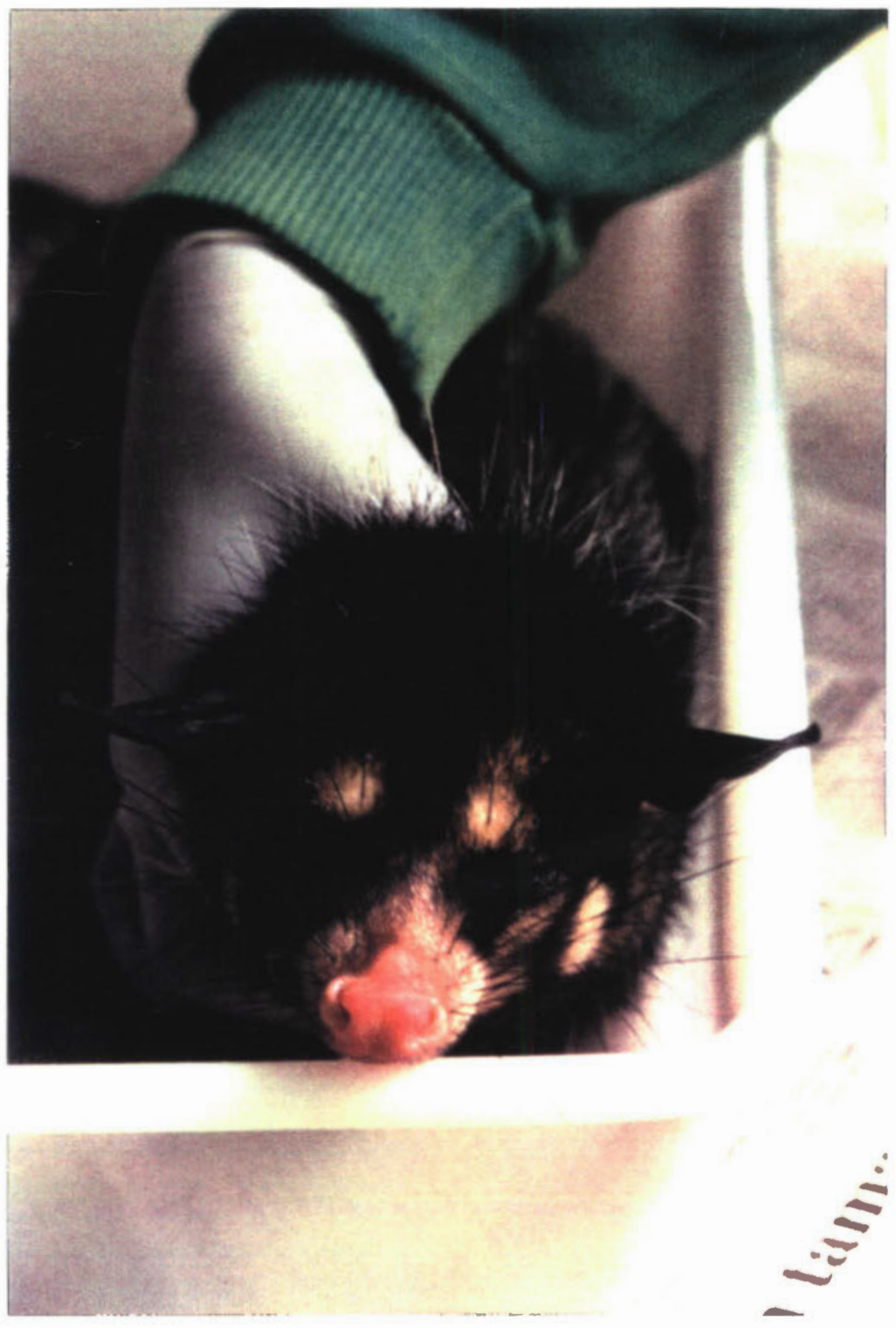

Figura 9. Exemplar macho de um gambá adulto da espécie Didelphis marsupialis (Didelphidae: Didelphidia) capturado no condomínio Transurb, em Itapevi, SP. 


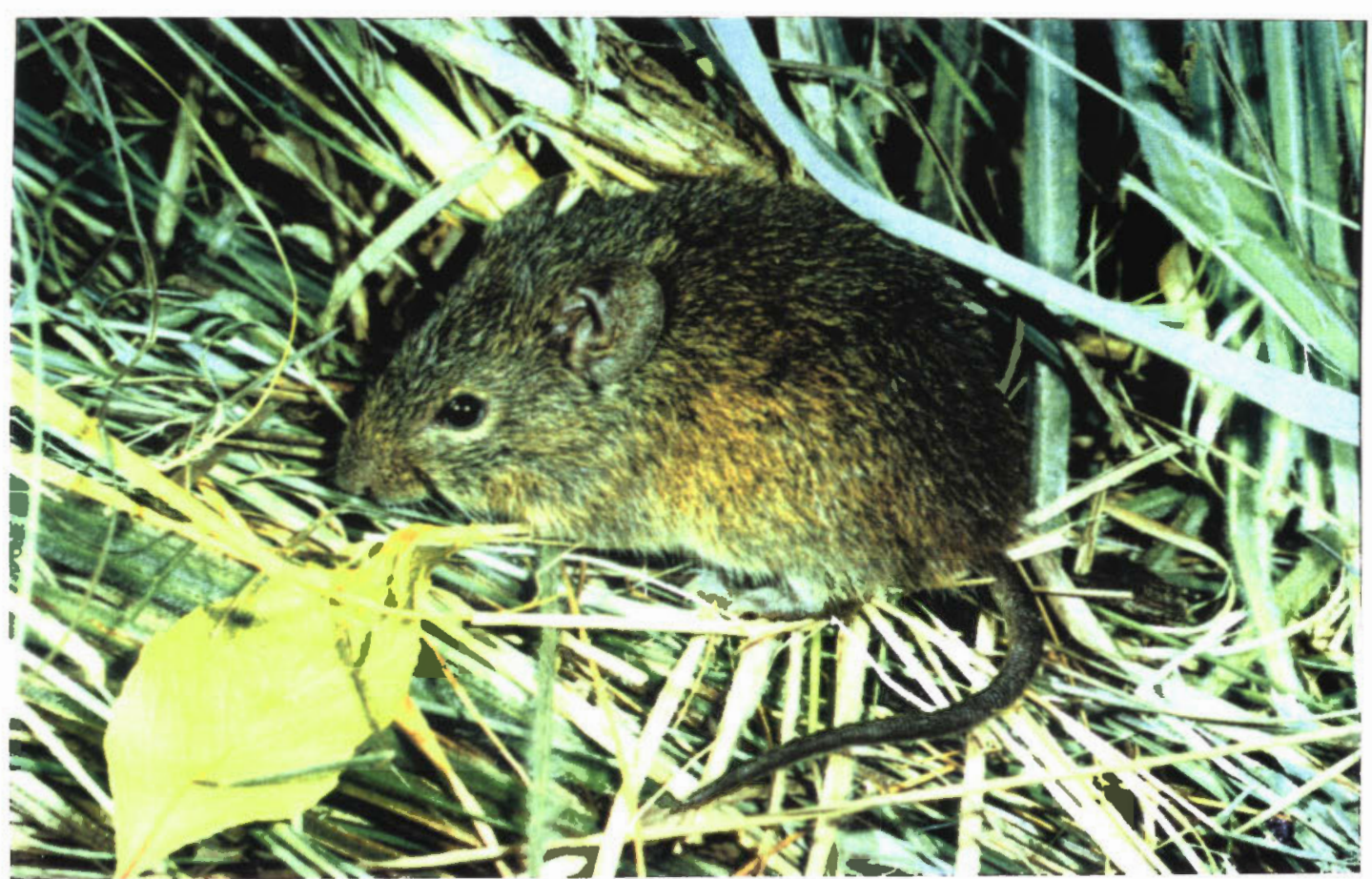

Figura 10. Akodon cursor (Muridae: Rodentia) em ambiente natural.

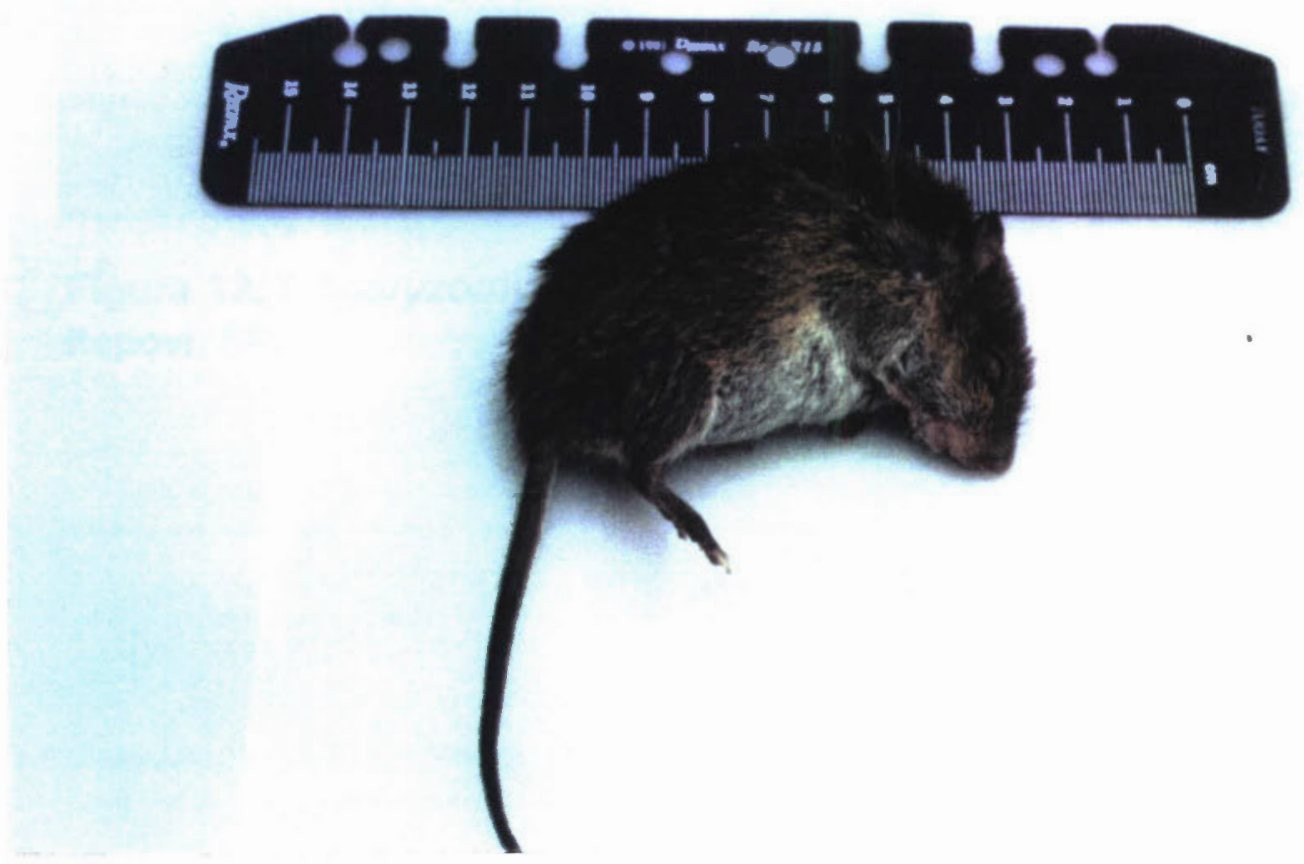

Figura 11. Bolomys lasiurus (Muridae: Rodentia), capturado em Itapevi, SP. 


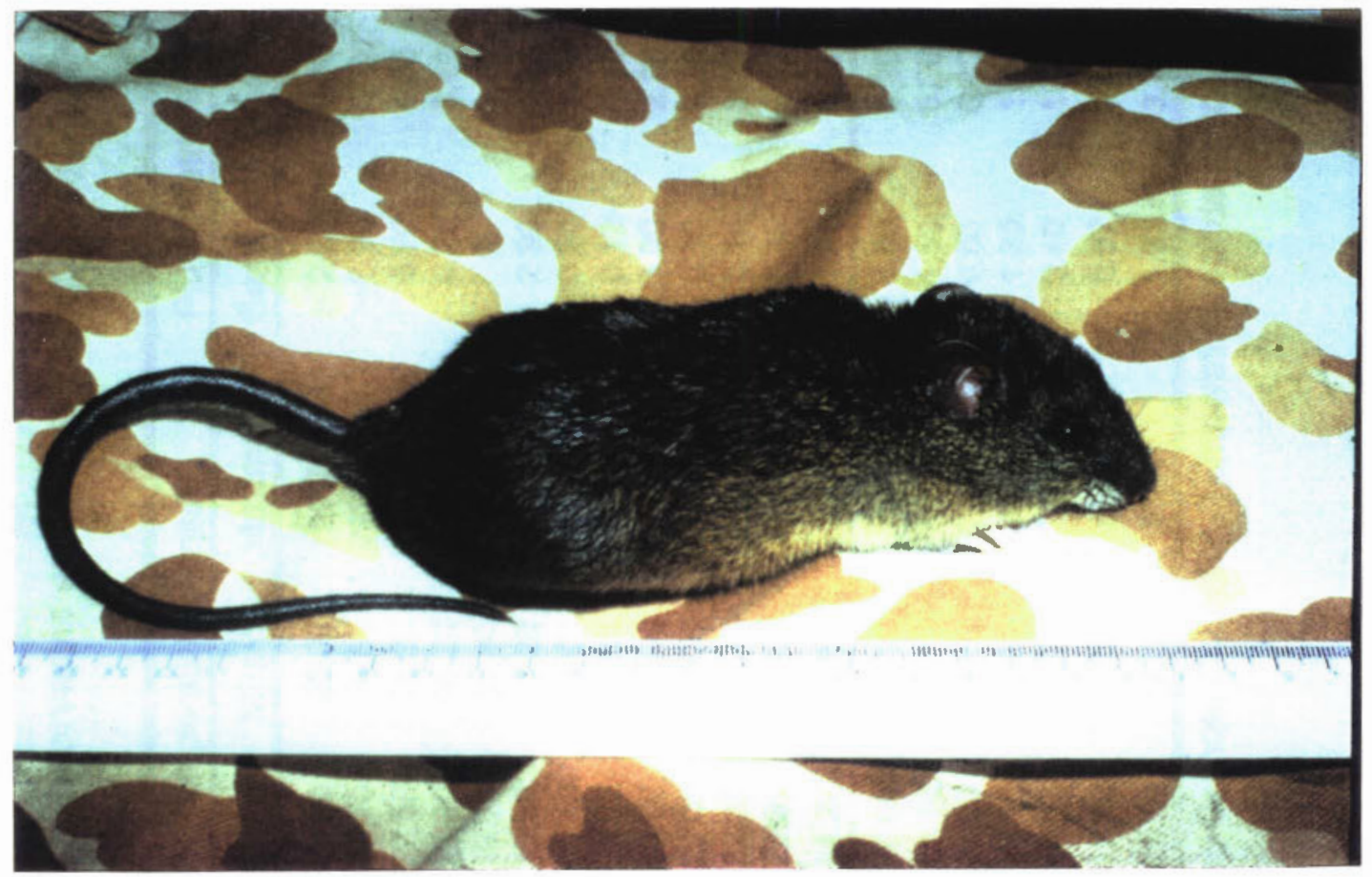

Figura 12. Oligoryzomys nigripes (Muridae: Rodentia) capturado em Itapevi, SP. 
Tabela 2. Temperatura $\left({ }^{\circ} \mathrm{C}\right)$ e pluviometria $\left(\mathrm{mm}^{3}\right)$ observadas entre Janeiro de 1995 e Junho de 1996, em Itapevi, SP.

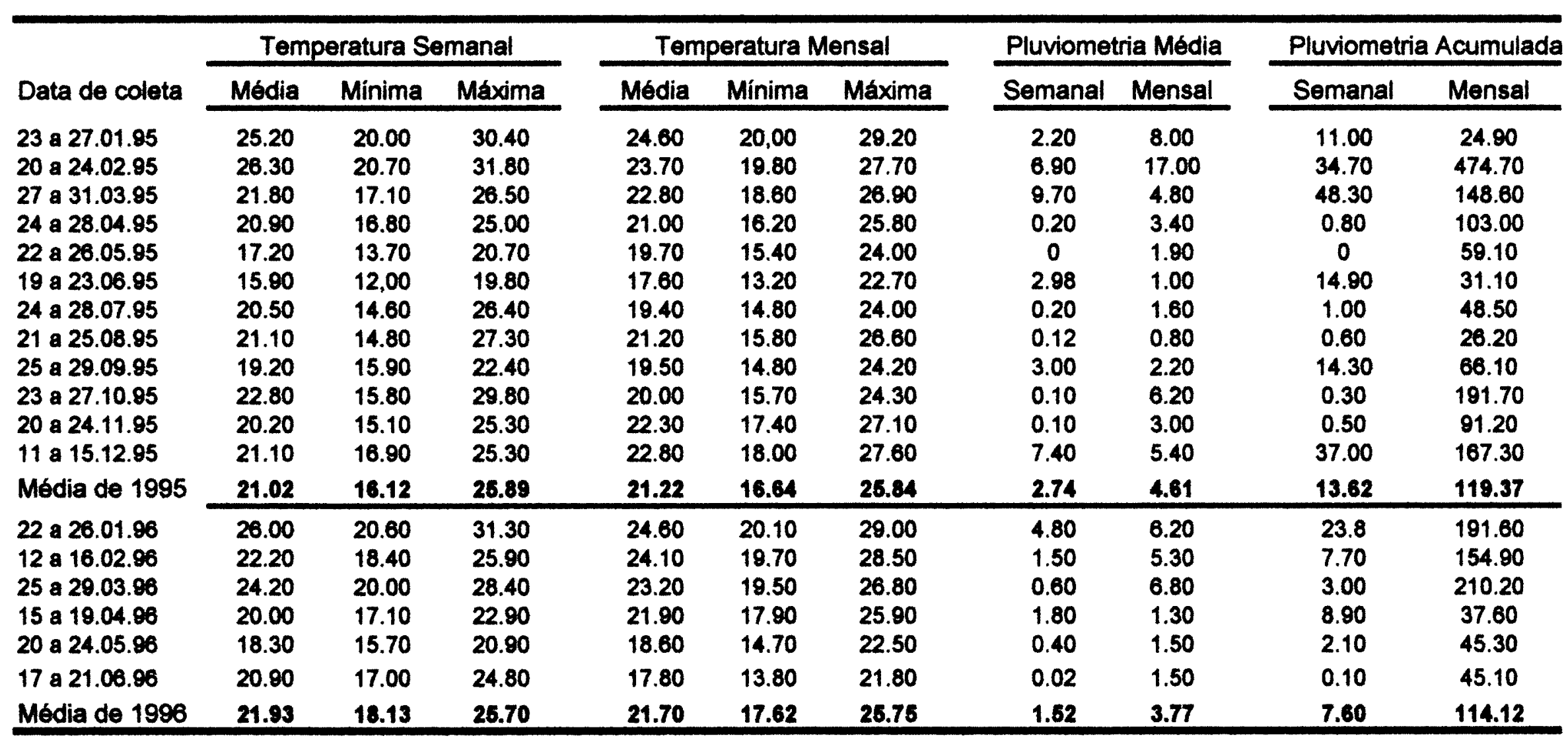

Pluviometria fornecida pela SABESP, estaçáo de Morro Grande, Cotia, SP. Temperatura obtida no local de coletas. 
Tabela 3. Número de animais coletados e indice mensal de densidade relativa de marsupiais (IDRM), roedores (IDRR) e carrapatos (IDRC), entre Janeiro/1995 e Junho/1996, om ItapevI, SP.

\begin{tabular}{|c|c|c|c|c|c|c|c|c|c|}
\hline \multirow[b]{2}{*}{ Meses * } & \multicolumn{3}{|c|}{ Marsupiais } & \multicolumn{3}{|c|}{ Roedores } & \multicolumn{2}{|c|}{ Carrapatos } & \multirow{2}{*}{$\begin{array}{c}\text { Total/Mamiferos } \\
\text { Capturados }\end{array}$} \\
\hline & Armadilhas ** & $N^{\circ}$ Exemplares & IDRM & Armadilhas ** & $N^{\circ}$ Exemplares & IDRR & No Exemplares & IDRC & \\
\hline Jan/95 & 12.60 & 2 & 3.17 & 12.00 & - & 0 & 15 & 150.00 & 2 \\
\hline Fev/95 & 15.20 & 5 & 6.58 & 12.00 & 1 & 1.67 & 2 & 6.70 & 6 \\
\hline Mar/95 & 12.20 & $7(4)$ & 11.48 & 11.20 & 1 & 1.79 & 5 & 12.50 & 8 \\
\hline Abr/95 & 12.20 & 6 & 8.84 & 10.00 & 4 & 8.00 & 2 & 4.00 & 10 \\
\hline Mai/85 & 13.60 & $3(2)$ & 4.41 & 9.20 & 5 & 10.87 & 1 & 2.50 & 8 \\
\hline Jun/85 & 12.80 & $5(1)$ & 7.81 & 6.40 & 10 & 31.25 & - & 0 & 15 \\
\hline Jul/95 & 15.00 & $2(1)$ & 2.67 & 9.00 & 7 & 15.56 & 3 & 6.70 & 9 \\
\hline Ago/95 & 12.80 & 3 & 4.69 & 22.80 & 8 & 7.02 & 28 & 59.80 & 11 \\
\hline Set/95 & 12.00 & 5 & 8.33 & 23.20 & 6 & 5.17 & 8 & 15.50 & 11 \\
\hline Out/95 & 14.80 & 2 & 2.70 & 23.60 & 6 & 5.08 & 1 & 2.50 & 8 \\
\hline Nov/95 & 14.60 & $3(1)$ & 4.11 & 24.60 & 3 & 2.43 & 4 & 13.30 & 6 \\
\hline Dez/95 & 14.00 & 2 & 2.86 & 26.40 & 1 & 0.76 & 1 & 6.70 & 3 \\
\hline $\operatorname{Jan} / 96$ & 12.60 & $3(1)$ & 4.76 & 25.40 & 3 & 2.36 & 1 & 3.30 & 6 \\
\hline Fev/96 & 15.60 & 1 & 1.28 & 23.20 & 4 & 3.45 & 1 & 4.00 & 5 \\
\hline Mar/96 & 14.60 & 2 & 2.74 & 26.00 & - & 0 & 3 & 30.00 & 2 \\
\hline Abr/98 & 13.20 & 4 & 6.06 & 24.80 & 2 & 1.61 & 5 & 16.70 & 6 \\
\hline Mai/96 & 13.80 & 3 & 4.35 & 18.80 & 7 & 7.07 & 4 & 8.00 & 10 \\
\hline Jun/96 & 14.40 & 4 & 5.56 & 22.00 & 4 & 3.64 & 4 & 10.00 & 8 \\
\hline
\end{tabular}

* 5 dias trabalhados/més; * , número médio mensal de armadilhas; 1, média mensal de mamíferos capturados (7.4); Número de marsupiais recapturados entre parénteses. 
Tabela 4. Coeficiente de correlaçâo de Pearson ( $=r)$ e Spearman (=rs), entre parénteses os níveis descritivos (ap) do teste de hipóte nula de assoclaçto entre os dados meteorológlcos e os números absolutos e índices de densidade relativa de marsupiais (IDRM), roedores (IDRR) e carrapatos (IDRC) coletados entre Janeiro/1995 e Junho/1996, om Itapevi, SP.

\begin{tabular}{|c|c|c|c|c|c|c|}
\hline Dados Meteorológicos & $N^{\circ}$ de Marsupiais & IDRM & $N^{\circ}$ de Roedores & IDRR & $N^{0}$ de Carrapatos & IDRC \\
\hline \multirow[t]{2}{*}{$T M M$} & -0.284 & -0.189 & -0.73 & -0.625 & -0.16 & 0.363 \\
\hline & $(0.241)$ & $(0.453)$ & $(0.005)$ & $(0.007)$ & 0.523 & 0.139 \\
\hline \multirow[t]{2}{*}{ TMS } & -0.298 & -0.216 & -0.499 & -0.646 & -0.212 & 0.35 \\
\hline & $(0.220)$ & $(0.389)$ & $(0.053)$ & $(0.005)$ & 0.400 & 0.154 \\
\hline \multirow[t]{2}{*}{$P M M$} & -0.294 & -0.075 & -0.617 & -0.402 & -0.412 & 0.146 \\
\hline & $(0.226)$ & $(0.768)$ & $(0.017)$ & $(0.109)$ & 0.100 & 0.562 \\
\hline \multirow[t]{2}{*}{ PMS } & 0.228 & 0.414 & -0.463 & -0.217 & 0.078 & -0.8 \\
\hline & $(0.347)$ & $(0.087)$ & $(0.073)$ & $(0.403)$ & 0.754 & 0.752 \\
\hline \multirow[t]{2}{*}{ PAM } & -0.306 & -0.091 & -0.594 & -0.42 & -0.411 & 0.173 \\
\hline & $(0.206)$ & $(0.719)$ & $(0.022)$ & $(0.093)$ & 0.100 & 0.492 \\
\hline \multirow[t]{2}{*}{ PAS } & 0.228 & 0.414 & -0.463 & -0.217 & 0.078 & -0.08 \\
\hline & $(0.347)$ & $(0.087)$ & $(0.073)$ & $(0.403)$ & 0.754 & 0.752 \\
\hline
\end{tabular}

TTM, temperatura média mensal; TMS, temperatura média semanal; PAM, pluviometria acumulada mensal; PAS, pluviometria acumulada semanal; PMM, pluviometria média mensal; PMS, pluviometria média semanal. As correlaçőes significativas estão destacadas em negrito. 
pluviometria média mensal e pluviometria acumulada mensal. Para o índice de densidade relativa de roedores (IDRR), houve correlação significativa com a temperatura média semanal e mensal. Os diagramas de dispersão que representam as correlações significativas estăo demonstrados nas Figuras 13, $14,15,16$ e 17. Tanto para marsupiais e carrapatos como para seus indices de densidade relativa, respectivamente (IDRM) e (IDRC), não houve correlaçăo com nenhuma das variáveis meterológicas.

Ao serem comparadas as estações seca-fria e chuvosa-quente em relaçăo à abundância de pequenos mamíferos (Figura 18), observou-se que na estação seca-fria as capturas foram $50 \%$ maiores $(N=88)$ do que na estação chuvosa-quente $(\mathrm{N}=46)$, considerando marsupiais e roedores. Esta diferença foi significativa $(p=0.045)$ pelo teste de Fisher.

Para o número de carrapatos e o IDRC, desconsiderando os diferentes estágios biológicos, as correlações não foram significantes com nenhuma das variáveis meteorológicas quando analisadas mensalmente. Porém, segundo as estações sazonais (Figura 19), houve predominância de carrapatos coletados na estação seca-fria $(\mathrm{N}=55)$ em relação à chuvosa-quente $(\mathrm{N}=33)$, entre adultos e imaturos, sendo esta diferença significativa $(p=0.019)$ pelo teste qui-quadrado.

Considerando os diferentes estágios de carrapatos (Tabela 1), os exemplares imaturos (larvas e ninfas de lxodes sp.), foram coletados principalmente em roedores, sendo mais abundantes durante a estaçăo secafria. Nestes hospedeiros, nenhum exemplar adulto foi encontrado. Poucos individuos imaturos de lxodes sp. foram coletados em Didelphis marsupialis, sendo que a totalidade de adultos foi predominante neste hospedeiro, com maior abundância durante a estação chuvosa-quente. A diferença entre as proporções dos estágios de carrapatos nos hospedeiros em ambas as estações sazonais (Figura 20), foi significativa pelo Teste de Fisher $(p=0.001)$.

Os carrapatos colhidos nos mamíferos durante as estações seca-fria e chuvosa-quente, segundo o estágio biológico, sexo e ingurgitamento de larvas, 

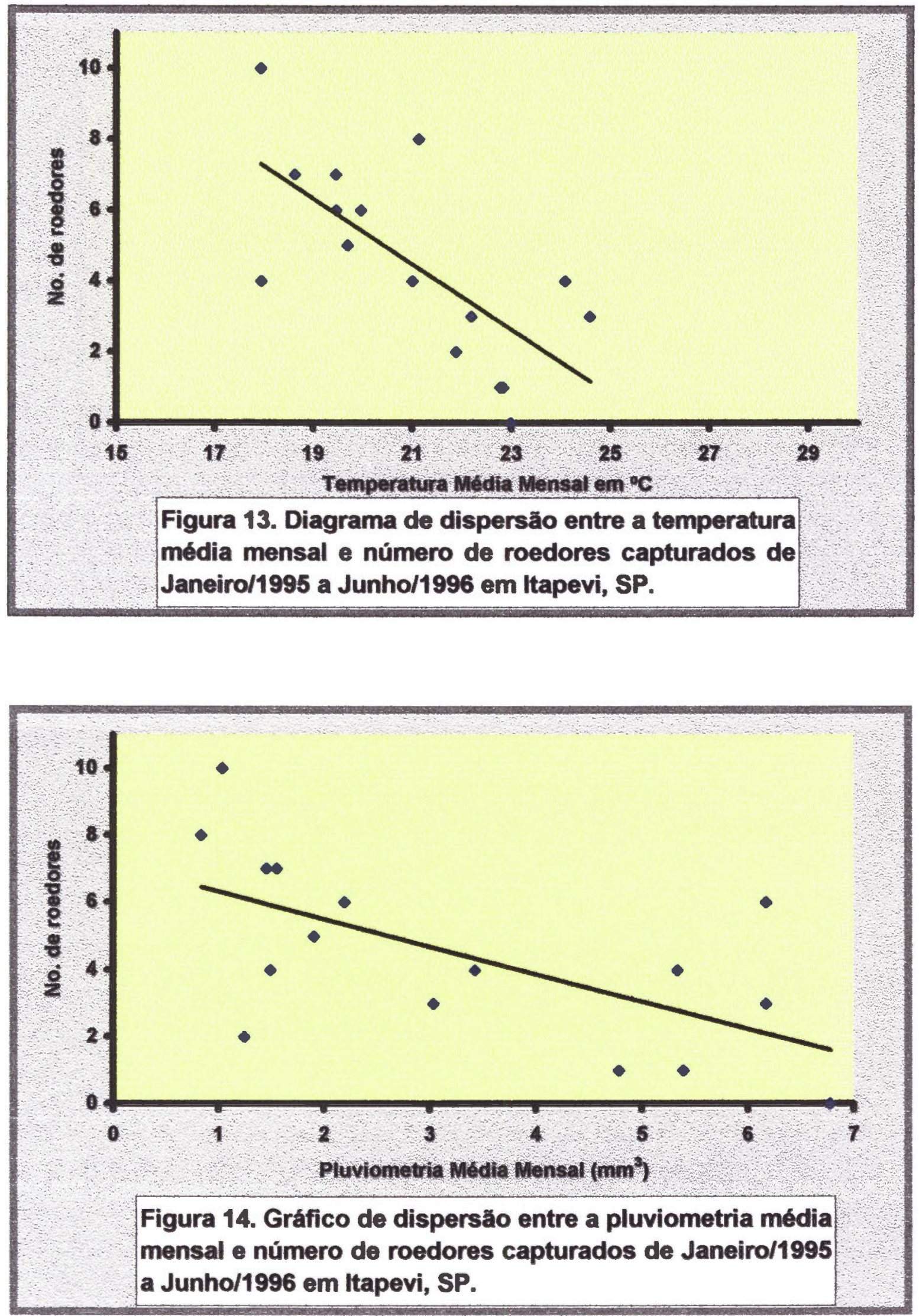

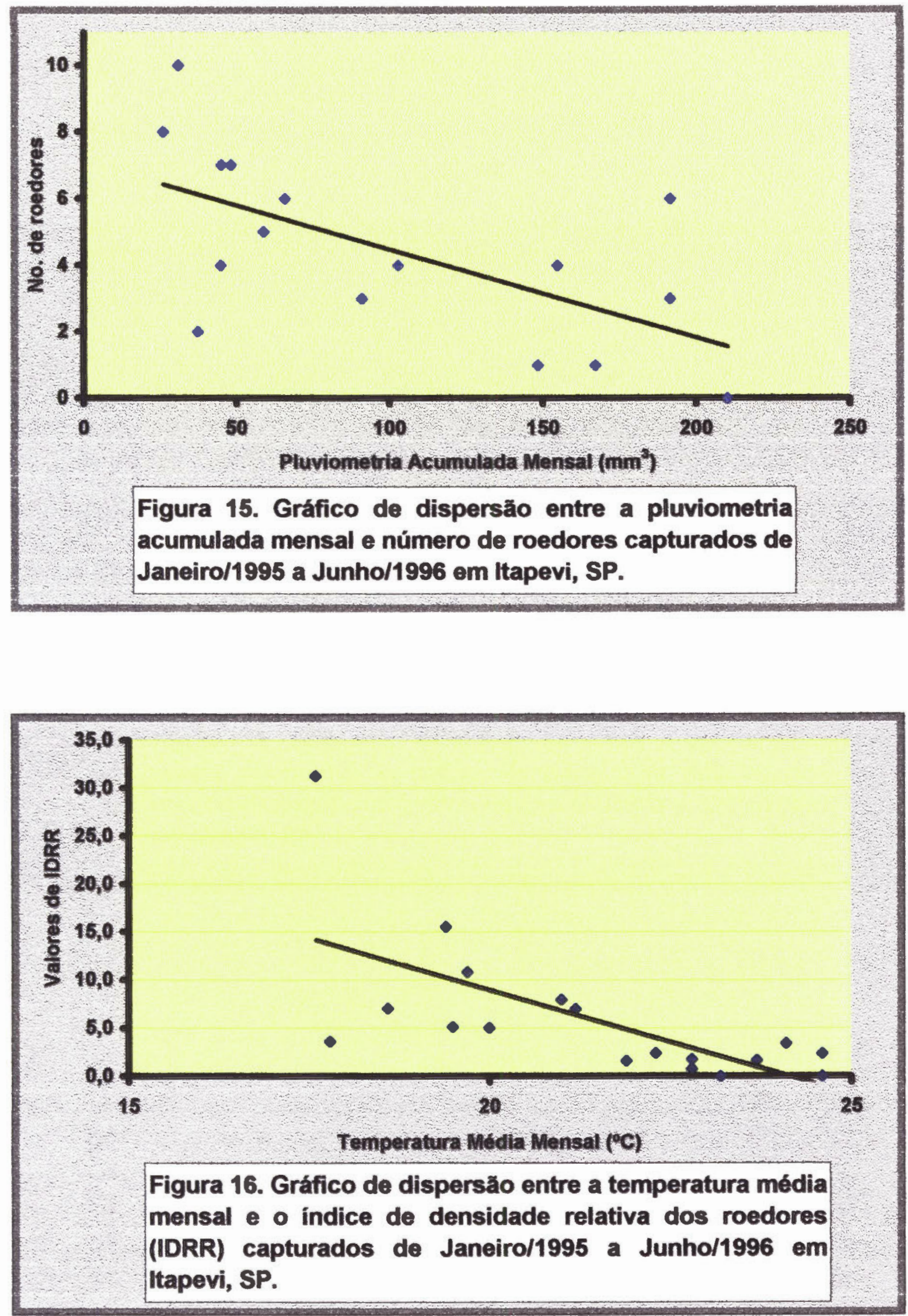


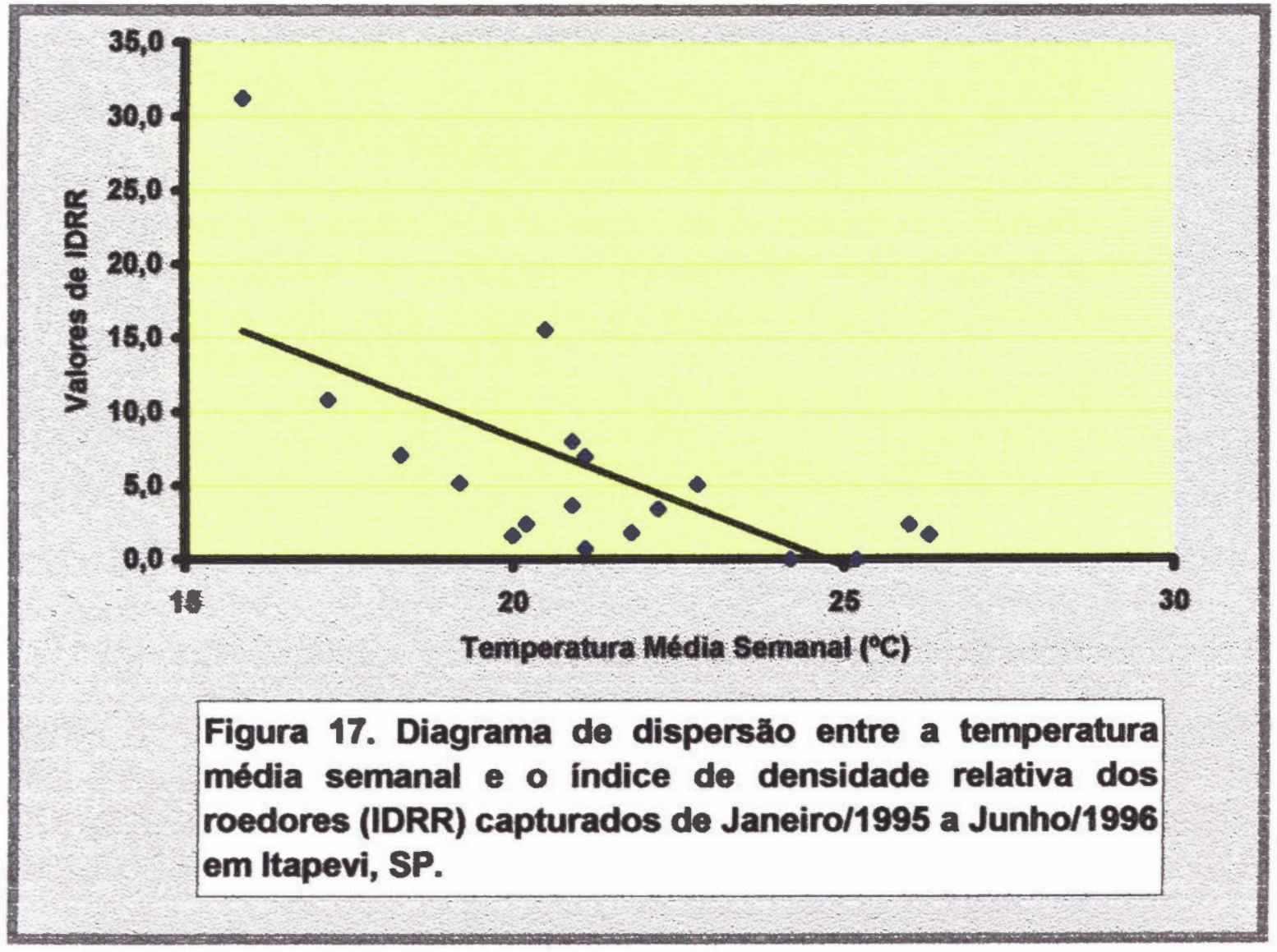



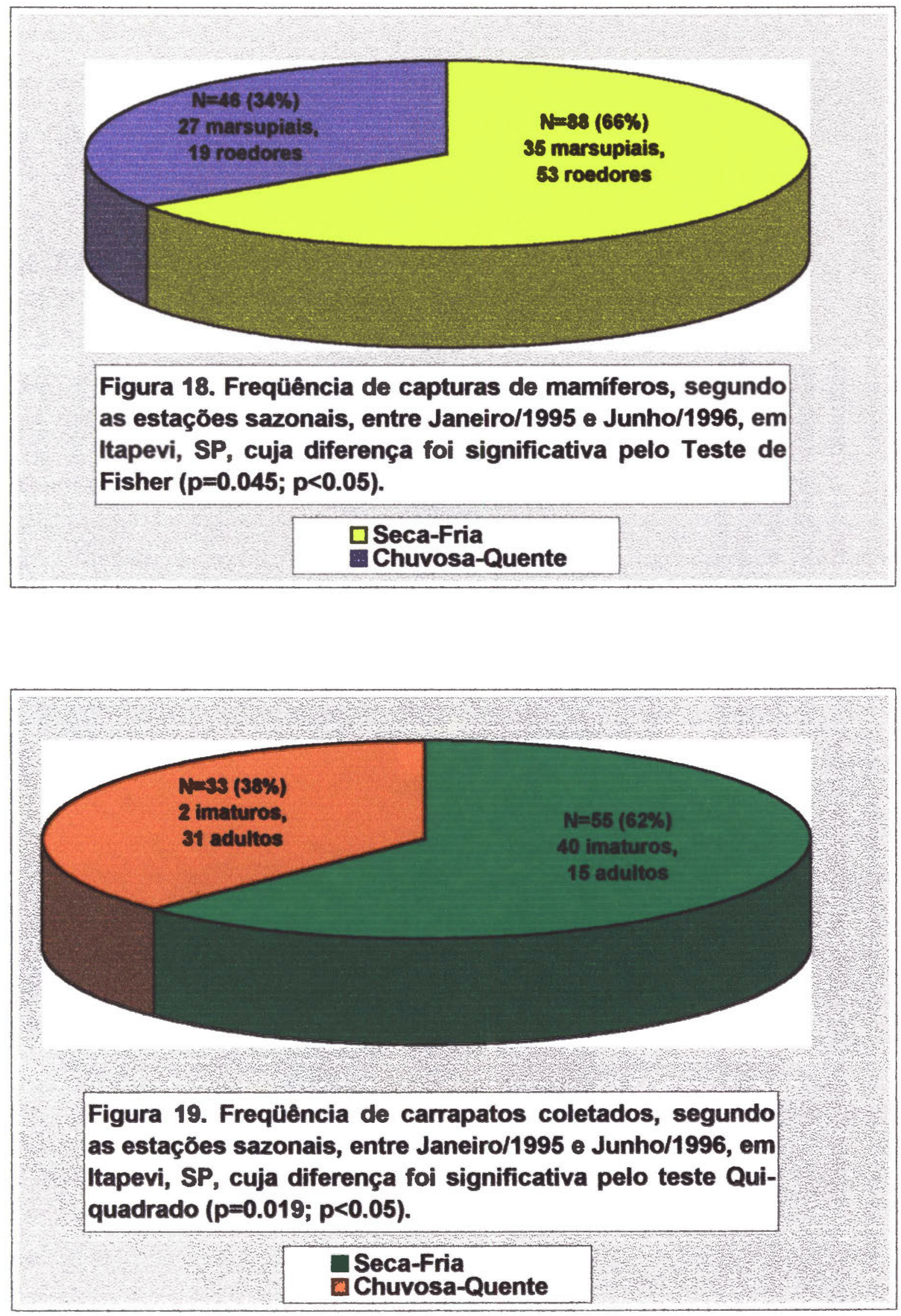


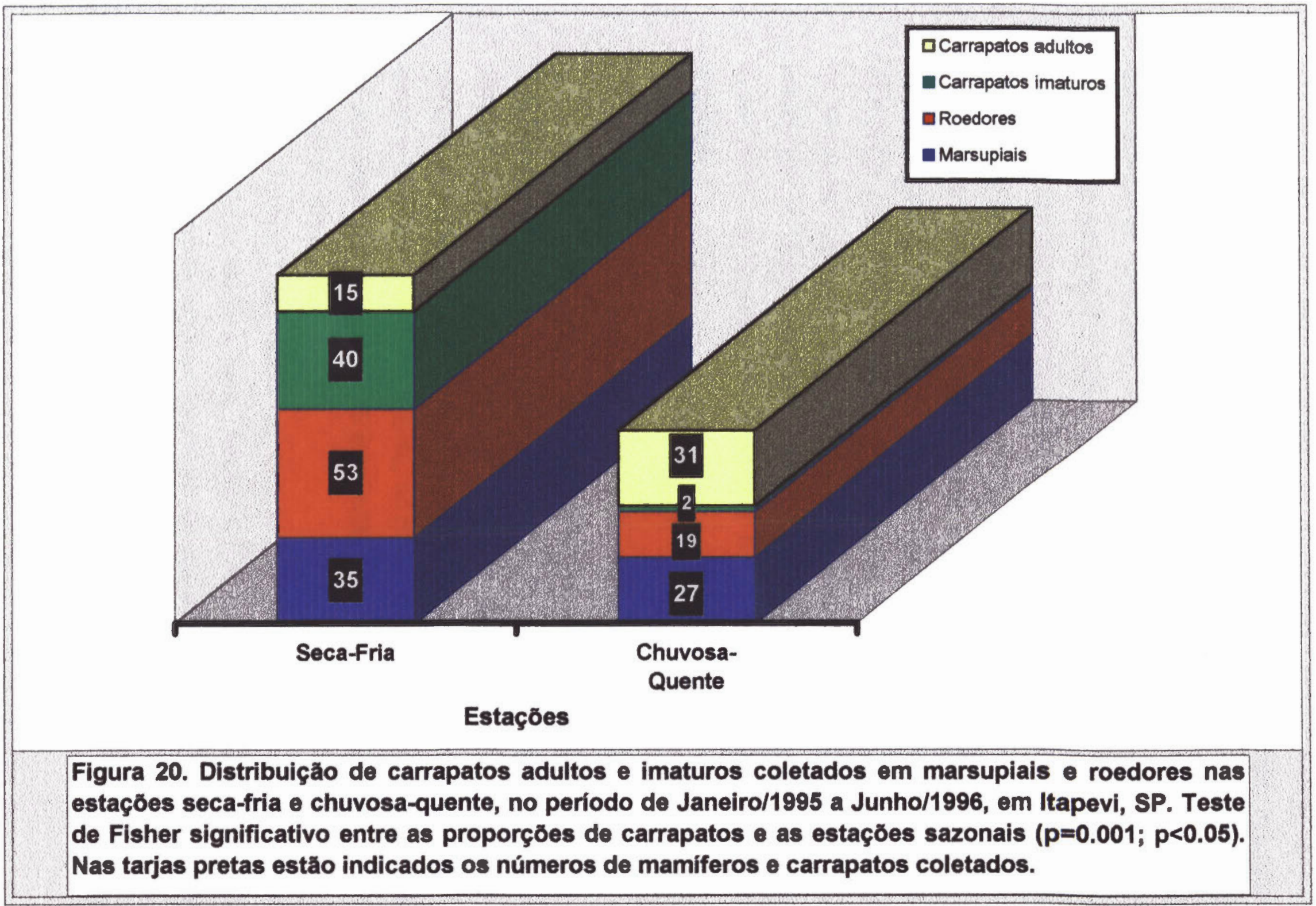


ninfas e fêmeas, podem ser verificados na Tabela 5.

As larvas e ninfas de Ixodes sp. ingurgitaram principalmente durante a estaçăo seca-fria, havendo uma porcentagem maior de fêmeas ingurgitadas durante a estação chuvosa-quente. Em I. dide/phidis, o número de exemplares machos foi superior ao de fêmeas, sendo duas vezes maior na estaçăo chuvosa-quente; entretanto, machos de I. loricatus foram coletados somente durante esta estaçăo e o número de fémeas foi muito superior ao de machos. A espécie Amblyomma cajennense foi representada por uma única fêmea estando no início do processo de ingurgitamento. A relação sexual macho/fêmea para $I$. didelphidis e I. loricatus, respectivamente, foi de 2:1 (13/6) e 1:6 (4/22).

A distribuiçăo mensal dos diferentes estágios biológicos das espécies de carrapatos coletadas nos mamíferos silvestres, em relação aos dados mensais de temperatura média e pluviometria média, está ilustrada na Figura 21. Dois meses após a temperatura média atingir seu valor mínimo e durante o menor indice médio de pluviometria registrados, houve predominância de carrapatos imaturos.

\section{V.1.3. Prevaléncia mensal e índices de infestaçăo}

A prevalência mensal de carrapatos imaturos $\theta$ adultos por grupo de hospedeiro e os indices totais em marsupiais e roedores, encontram-se demonstrados na Tabela 6. Em marsupiais, o maior índice de infestaçăo de carrapatos registrado por hospedeiro, foi em Janeiro/1995, com indice nulo em Junho e Outubro/1995. Em roedores, só houve infestação nos meses de Abril, Agosto, Setembro, Outubro/1995 e Maio/96, com o maior indice registrado por hospedeiro, em Agosto/1995.

A Tabela 7 apresenta os indices de infestaçăo parasito/hospedeiro segundo a faixa etária e sexo. Apesar de $A$. cursor ter sido o roedor mais capturado, somente machos foram infestados e o indice de infestaçăo total parasito por hospedeiro foi $(7 / 30,0.23)$, sendo em jovens e adultos, respectivamente, $(1 / 10,0.1 ; 6 / 20,0.3)$. O maior índice total foi registrado para 
Tabela 5. Carrapatos coletados em mamíferos durante as estaçoes sazonais, entre Janeiro/1995 e Junho/1996, em Itapevi, SP, segundo os estágios biológicos, sexo e ingurgitamento de imaturos e fêmeas.

\begin{tabular}{|c|c|c|c|c|c|c|c|}
\hline \multirow{3}{*}{ Espécie } & \multirow{3}{*}{ Estagio } & \multicolumn{4}{|c|}{ Estaçōes } & & \\
\hline & & \multicolumn{2}{|c|}{ Seca-fria } & \multicolumn{2}{|c|}{ Chuvosa-quente } & \multicolumn{2}{|c|}{ Total } \\
\hline & & $N^{0}(")$ & $\% *$ & $N^{0}()$ & $\% *$ & $N^{0}(n)$ & $\% *$ \\
\hline \multirow[t]{2}{*}{ lxodes sp. } & Larvas & $18\left(18^{7}\right)$ & 100 & - & - & $18(18)$ & 100 \\
\hline & Ninfas & $22\left(22^{*}\right)$ & 100 & $2\left(2^{*}\right)$ & 100 & $24(24)$ & 100 \\
\hline \multirow[t]{2}{*}{ I.didelphidis } & Machos & $4\left(1^{*}\right)$ & 25 & $9\left(3^{*}\right)$ & 33 & $13(4)$ & 31 \\
\hline & Femeas & $3\left(3^{4}\right)$ & 100 & $3\left(3^{n}\right)$ & 100 & $6(6)$ & 100 \\
\hline \multirow[t]{2}{*}{ 1. lonicatus } & Machos & - & - & $4\left(2^{*}\right)$ & 50 & $4\left(2^{*}\right)$ & 50 \\
\hline & Femeas & $8\left(3^{4}\right)$ & 38 & $14\left(14^{*}\right)$ & 100 & $22(17)$ & 77 \\
\hline \multirow[t]{2}{*}{ A. cajennense } & Machos & - & - & - & - & - & - \\
\hline & Femeas & - & - & $1\left(1^{*}\right)$ & 100 & $1\left(1^{*}\right)$ & 100 \\
\hline Total & & $55\left(47^{*}\right)$ & 85 & $33(25)$ & 75 & $88(72)$ & 81 \\
\hline
\end{tabular}

$\mathrm{N}^{\circ}$, número de exemplares; ("), espécimens engurgitados; \%*, porcentagem de ingurgitados. 


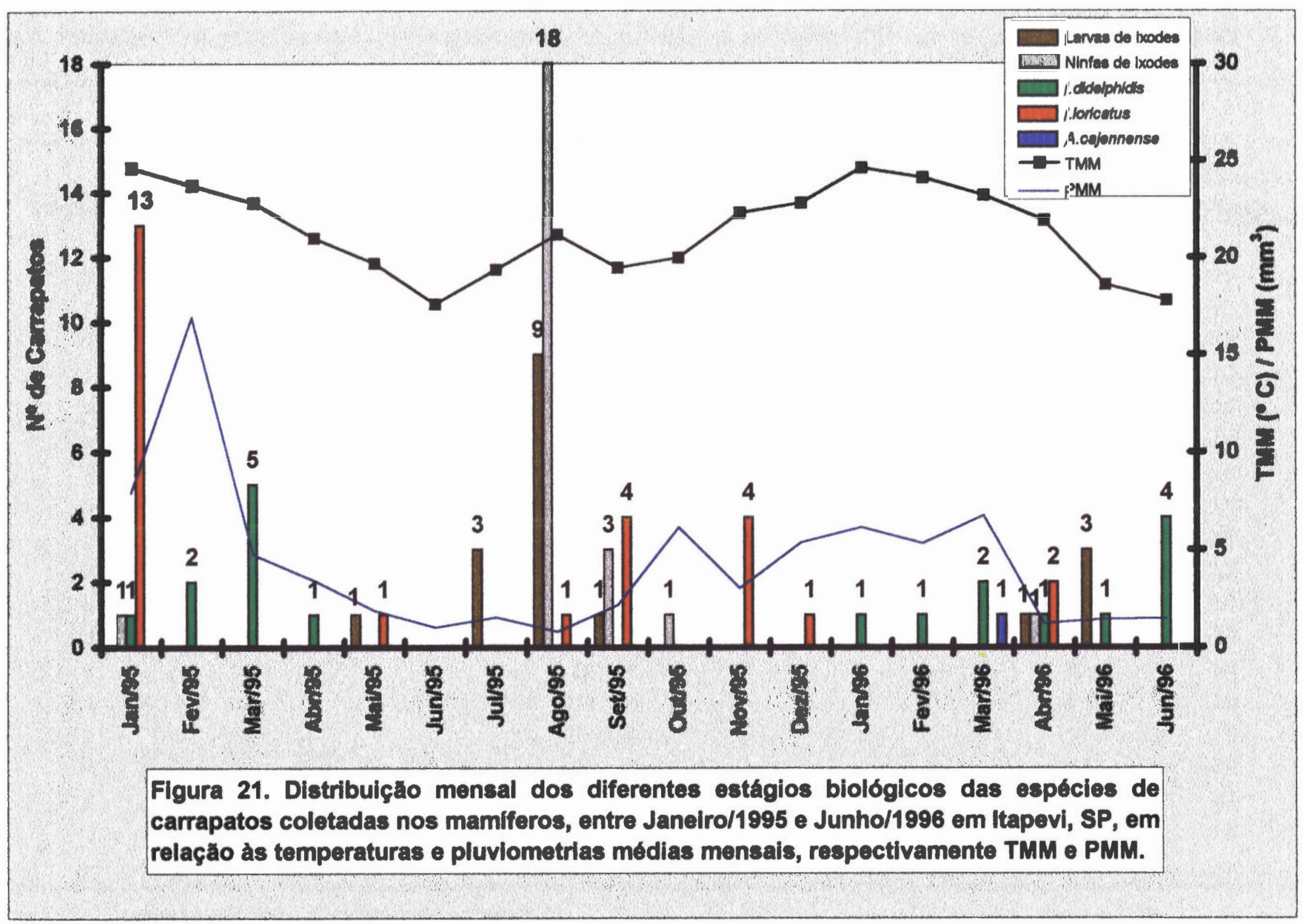


Tabela 6. Prevalencia mensal de carrapatos coletados nos mamiferos de ltapevl - SP, entre Janeiro/1996 e Junho/1996.

\begin{tabular}{|c|c|c|c|c|c|c|c|c|c|c|c|c|c|c|c|c|}
\hline \multirow[b]{3}{*}{ Meses } & \multirow[b]{3}{*}{ Hospedeiros } & \multicolumn{9}{|c|}{ Carrapatos em Marsupiais } & \multicolumn{4}{|c|}{ Carrapatos em Roedores } & \multirow{2}{*}{\multicolumn{2}{|c|}{ Indices Totais }} \\
\hline & & \multicolumn{3}{|c|}{ Total } & \multicolumn{3}{|c|}{ Imaturos } & \multicolumn{3}{|c|}{ Adultos } & \multirow[b]{2}{*}{ Hospedeiros } & \multicolumn{3}{|c|}{ Imaturos } & & \\
\hline & & $\mathbf{N}^{\circ}$ & $\%$ & $n$ & $N^{\bullet}$ & $\%$ & $\mathbf{n}$ & $N^{0}$ & $\%$ & $n$ & & $\mathbf{N}$ & $\%$ & n & Por Marsupial & Por Roedor \\
\hline $\operatorname{Jan} / 85$ & 2 & 2 & 100 & 15 & 1 & 50 & 1 & 2 & 100 & 14 & - & - & - & - & 7.5 & 0.0 \\
\hline Fev/95 & 5 & 2 & 40 & 2 & - & - & - & 2 & 40 & 2 & 1 & - & - & - & 0.4 & 0.0 \\
\hline Mar/95 & 7 & 1 & 25 & 5 & - & - & - & 1 & 25 & 5 & 1 & - & - & - & 0.7 & 0.0 \\
\hline Abr/95 & 6 & 1 & 17 & 1 & - & - & - & 1 & 17 & 1 & 4 & 1 & 25 & 1 & 0.2 & 0.3 \\
\hline Mai/95 & 3 & 1 & 33 & 1 & - & - & - & 1 & 33 & 1 & 5 & - & - & - & 0.3 & 0.0 \\
\hline Jun/95 & 5 & - & - & - & - & - & - & - & - & - & 10 & - & - & - & 0.0 & 0.0 \\
\hline Jul/95 & 2 & 1 & 50 & 3 & 1 & 50 & 3 & - & - & - & 7 & - & - & - & 1.5 & 0.0 \\
\hline Ago/95 & 3 & 1 & 33 & 1 & - & - & - & 1 & 33 & 1 & 8 & 8 & 100 & 27 & 0.3 & 3.0 \\
\hline Set/95 & 5 & 4 & 80 & 7 & 2 & 40 & 3 & 3 & 60 & 4 & 6 & 1 & 17 & 1 & 1.4 & 0.2 \\
\hline Out/95 & 2 & - & - & - & - & - & - & - & - & - & 6 & 1 & 17 & 1 & 0.0 & 0.2 \\
\hline Nov/95 & 3 & 2 & 67 & 4 & - & - & - & 2 & 67 & 4 & 3 & - & - & - & 1.3 & 0.0 \\
\hline Dez/95 & 2 & 1 & 50 & 1 & - & - & - & 1 & 50 & 1 & 1 & - & - & - & 0.5 & 0.0 \\
\hline $\operatorname{Jan} / 98$ & 3 & 1 & 33 & 1 & - & - & - & 1 & 33 & 1 & 3 & - & - & - & 0.3 & 0.0 \\
\hline Fev/98 & 1 & 1 & 100 & 1 & - & - & - & 1 & 100 & 1 & 4 & - & - & - & 1.0 & 0.0 \\
\hline Mart98 & 2 & 2 & 100 & 3 & - & - & - & 2 & 100 & 3 & - & - & - & - & 1.5 & 0.0 \\
\hline Abr/90 & 4 & 2 & 50 & 5 & 1 & 25 & 2 & 2 & 50 & 3 & 2 & - & - & - & 1.3 & 0.0 \\
\hline Mai/96 & 3 & 1 & 33 & 1 & - & - & - & 1 & 33 & 1 & 7 & 2 & 28 & 3 & 0.3 & 0.4 \\
\hline Jun/98 & 4 & 3 & 75 & 4 & - & - & - & 3 & 75 & 4 & 4 & - & - & - & 1.0 & 0.0 \\
\hline TOTAL & 62 & 28 & 42 & 55 & 5 & 8 & 9 & 24 & 30 & 46 & 72 & 13 & 18 & 33 & 0.9 & 0.5 \\
\hline
\end{tabular}

$N^{\circ}$, número de hospedeiro infestado; $n$, número de carrapatos. 
Tabela 7. Prevalência de infestaçăo parasito/hospedeiro, segundo as espécies de mamíferos, faixa etárla e sexo, entre Janeiro/1995 e Junho/1996, em Itapevi, SP.

\begin{tabular}{|c|c|c|c|c|c|c|c|c|c|c|c|c|c|c|c|}
\hline \multirow[b]{2}{*}{ Hospedeiros } & \multicolumn{5}{|c|}{ Total } & \multicolumn{5}{|c|}{ Jovens } & \multicolumn{5}{|c|}{ Adultos } \\
\hline & $N$ & $\mathrm{~N}^{\circ}$ & $\%$ & $n(\%)$ & Indice & $N$ & No/Sexo & $\%$ & $n(\%)$ & Indice & $N$ & No/Sexo & $\%$ & n (\%) & Índice \\
\hline A. cursor & 30 & 4 & 13.3 & $7(21.2)$ & 0.23 & 10 & $1 / M$ & 10.0 & $1(16.7)$ & 0.1 & 20 & $3 / M$ & 15.0 & $6(22.2)$ & 0.3 \\
\hline B. lasiunus & 13 & 2 & 15.4 & $3(0.1)$ & 0.23 & 8 & $2 / M$ & 25.0 & $3(50.0)$ & 0.4 & 5 & - & - & - & 0.0 \\
\hline 0. nigripes & 13 & 7 & 53.8 & $23(69.7)$ & 1.8 & 1 & $1 / M$ & 100.0 & $2(33.3)$ & 2.0 & 12 & $6 / 4 M / 2 F$ & 50.0 & $21(77.8)$ & 1.8 \\
\hline O. ratticeps & 1 & - & - & - & 0.0 & - & - & - & - & 0.0 & 1 & - & - & - & 0.0 \\
\hline O. hispidus & 6 & - & - & $\cdot$ & 0.0 & 1 & - & - & - & 0.0 & 5 & - & - & - & 0.0 \\
\hline O.nasutus & 5 & - & - & - & 0.0 & - & - & - & - & 0.0 & 5 & - & - & - & 0.0 \\
\hline E. spinosus & 2 & - & - & . & 0.0 & - & - & - & - & 0.0 & 2 & - & - & - & 0.0 \\
\hline R.norvogicus & 1 & - & - & . & 0.0 & - & - & - & - & 0.0 & 1 & - & - & - & 0.0 \\
\hline C. aperea & 1 & - & - & - & 0.0 & - & - & - & - & 0.0 & 1 & - & - & - & 0.0 \\
\hline Subtotal & 72 & 13 & 18.1 & $33(37.6)$ & 0.6 & 20 & $4 / M$ & 20.0 & $6(85.7)$ & 0.3 & 52 & 8/7M/2F & 17.3 & 27 (33.3) & 0.6 \\
\hline M. incenus & 1 & - & - & - & 0.0 & - & . & - & - & 0.0 & 1 & - & - & - & 0.0 \\
\hline D. marsupialis & 61 & 26 & 42.6 & $55(62.5)$ & 0.9 & 5 & $1 / F$ & 20.0 & $1(14.3)$ & 0.2 & 56 & $25 / 15 \mathrm{M} / 10 \mathrm{~F}$ & 44.6 & $54(86.7)$ & 1.0 \\
\hline Subtotal & 62 & 26 & 41.8 & $66(62.5)$ & 0.9 & 5 & $1 / F$ & 20.0 & $1(14.3)$ & 0.2 & 57 & 25/16M/10F & 43.8 & $84(66.7)$ & 0.9 \\
\hline Total & 134 & 39 & 29.1 & $88(100.0)$ & 0.7 & 25 & $5 / 4 M / 1 F$ & 20.0 & $7(100.0)$ & 0.3 & 109 & $34 / 22 \mathrm{M} / 12 \mathrm{~F}$ & 31.2 & $81(100.0)$ & 0.7 \\
\hline
\end{tabular}


O. nigripes $(23 / 13,1.8)$, sendo em jovens e adultos, respectivamente $(2 / 1,2.0$; 21/12, 1.8), onde 5 machos e 2 fêmeas foram parasitados. Para Bolomys lasiurus, a infestaçăo ocorreu somente em machos jovens e os índices foram, respectivamente, total e jovens $(3 / 13,0.23 ; 3 / 8,0.4)$. As outras espécies de roedores não tiveram infestação. Em marsupiais, o indice total registrado em $D$. marsupialis foi $(55 / 61,0.9)$, sendo em jovens e adultos, respectivamente (1/5, $0.2 ; 54 / 56,1.0)$. Excetuando uma fèmea jovem de $D$. marsupialis parasitada em Dezembro/1995, todos os outros hospedeiros parasitados eram adultos, sendo 15 machos e 10 fêmeas.

Para ambos, marsupiais e roedores, os machos $(26 / 65,40 \%)$ foram mais parasitados do que as fêmeas $(13 / 69,18.8 \%)$, havendo maior infestação em hospedeiros adultos $(34 / 109,31.2 \%)$ do que jovens $(5 / 25,20 \%)$, com exceção B. lasiurus. Entretanto estas diferenças năo foram significativas pelo teste Quiquadrado, cujos valores foram respectivamente, $p=0.33$ e $p=0.16$.

$\mathrm{Na}$ Tabela 8, estão demonstrados os dados biométricos e peso para as espécies de mamíferos na fase adulta, excetuando aquelas espécies de mamíferos representados apenas por um único exemplar ou por um exemplar de cada sexo. Foi verificado para os machos, maior peso e comprimento do corpo.

Considerando capturas e recapturas, foram capturados 26 exemplares machos e 35 fémeas de $D$. marsupialis. Dois jovens, D4 e D9 (respectivamente, fêmea e macho) foram recapturados uma ou duas vezes. Observou-se que a fêmea jovem (D4) capturada em Fevereiro/1995 foi recapturada em Março $\theta$ Maio/1995, mas no mês seguinte à primeira captura, ela adquiriu um ganho de peso três vezes maior e o dobro do comprimento total, estando já na fase adulta. O macho jovem (D9) capturado em Março/1995 foi recapturado como adulto em Julho/1995, pesando cinco vezes seu peso inicial atingindo o dobro do comprimento total em apenas quatro meses. Tanto na captura como nas recapturas, ambos fêmea e macho, năo apresentaram infestação com carrapatos. Foram ainda recapturados 5 exemplares adultos, sendo: 2 machos (D7, capturado em Fevereiro e Março/1995 e D15, capturado em Abril e 
Tabela 8. Dados biométricos dos mamiferos adultos capturados entre Janeiro/1995 e Junho/1996, em Itapevi, SP.

\begin{tabular}{|c|c|c|c|c|c|c|c|}
\hline & & & \multirow{3}{*}{$\frac{\text { Poso }}{\text { Média (DP) }}$} & \multicolumn{4}{|c|}{ Biometria } \\
\hline \multicolumn{3}{|c|}{ Mamíferos } & & \multirow{2}{*}{$\begin{array}{c}\text { Corpo+Cabeça } \\
\text { Média (DP) }\end{array}$} & \multirow{2}{*}{$\begin{array}{c}\text { Cauda } \\
\text { Média (DP) }\end{array}$} & \multirow{2}{*}{$\begin{array}{l}\text { Pata Posterior } \\
\text { Média (DP) }\end{array}$} & \multirow{2}{*}{$\begin{array}{c}\text { Altura da Orelha } \\
\text { Media (DP) }\end{array}$} \\
\hline Espécie & Sexo & $N$ & & & & & \\
\hline \multicolumn{8}{|l|}{ Didelphidia } \\
\hline \multirow[t]{2}{*}{ D. mersupialis } & $M$ & 24 & $1328.4(434.5)$ & $397.1(38.6)$ & $339.3(23.9)$ & $57.5(4.3)$ & $47.8(4.2)$ \\
\hline & $F$ & 32 & $1098.3(369.7)$ & $367.8(33.8)$ & $330.0(22.7)$ & $54.0(3.4)$ & $45.3(4.3)$ \\
\hline \multicolumn{8}{|l|}{ Rodentia } \\
\hline \multirow[t]{2}{*}{ A. cursor } & $\mathbf{M}$ & 10 & $44.6(3.5)$ & $118.1(6.9)$ & $87.6(5.6)$ & $22.5(1.5)$ & $17.8(1.2)$ \\
\hline & $F$ & 10 & $37.8(6.9)$ & $114.7(7.9)$ & $86.1(4.5)$ & $22.4(1.8)$ & $17.7(1.2)$ \\
\hline \multirow[t]{2}{*}{ B. kasiurus } & $M$ & 1 & $45.0(-)$ & $110.0(-)$ & $75.0(-)$ & $20.0(-)$ & $15.0(-)$ \\
\hline & $F$ & 4 & $40.5(13.9)$ & $107.3(19.2)$ & $74.5(8.0)$ & $20.0(3.4)$ & $15.0(0.8)$ \\
\hline \multirow[t]{2}{*}{ O. hispidus } & $M$ & 2 & $100.3(21.6)$ & $166.5(10.6)$ & $108.0(25.5)$ & $32.3(0.4)$ & $23.5(2.1)$ \\
\hline & $\mathbf{F}$ & 3 & $81.2(7.2)$ & $184.0(4.0)$ & $115.0(5.0)$ & $31.0(1.0)$ & $23.3(1.5)$ \\
\hline \multirow[t]{2}{*}{ O. nasutus } & $M$ & 3 & $57.4(4.6)$ & $147.3(5.5)$ & $87.3(2.5)$ & $24.3(0.6)$ & $17.7(1.2)$ \\
\hline & $F$ & 2 & $50.0(14.1)$ & $132.0(2.8)$ & $79.0(5.7)$ & $23.5(0.7)$ & $16.0(0)$ \\
\hline \multirow[t]{2}{*}{ O. nigripes } & $M$ & 7 & $23.9(3.4)$ & $98.7(6.7)$ & $121.4(2.8)$ & $23.0(0.8)$ & $15.9(0.7)$ \\
\hline & $F$ & 5 & $20.3(2.8)$ & $93.8(8.5)$ & $118.6(8.4)$ & $21.6(1.3)$ & $16.2(1.1)$ \\
\hline
\end{tabular}

$\mathrm{N}=$ número de indivíduos, peso em $\mathrm{g}$, biometria em $\mathrm{mm}, \mathrm{DP}=$ Desvio Padrăo. 
Junho/1995) e 3 fẻmeas (D3, capturada em Fevereiro, Março e Maio/1995; D6, em Fevereiro, Março e Novembro/1995 e, D35, em Dezembro/1995 e Janeiro/1996). Os machos D7 e D15 apresentaram-se infestados respectivamente, em Março e Abril; infestação com carrapatos foi também observada na fêmea D3, somente em Fevereiro e na fêmea D6, em Fevereiro e Novembro. A fêmea D35 não teve infestação em nenhuma das capturas.

Quanto à faixa etária dos mamíferos em relaçăo à sazonalidade, observou-se que os individuos adultos de $D$. marsupialis foram mais capturados na estaçăo seca-fria $(N=34)$ do que na chuvosa-quente $(N=22)$, embora esta diferença năo tenha sido significativa. Quatro indivíduos jovens foram observados durante a estação chuvosa-quente e somente 1 jovem na estação seca-fria.

Gambás fêmeas adultas em condições reprodutivas foram observadas na estação chuvosa-quente, tendo sido verificado 8 fêmeas lactantes e 10 fêmeas com filhotes no marsúpio. $O$ único exemplar de Marmosops incanus, uma fêmea adulta prenhe, foi capturada na estação chuvosa-quente (Novembro, 1995).

Dentre os roedores, Akodon cursor foi mais freqüente do que outras espécies (17 machos e 13 fêmeas), com adultos e jovens ocorrendo em ambas as estações. Para a espécie Bolomys lasiurus (6 machos e 7 fémeas), houve maior número de jovens do que adultos, ambos capturados principalmente durante a estação seca-fria, tendo somente um exemplar adulto durante a estação chuvosa-quente (Dezembro, 1995). Para Oxymycterus hispidus (2 machos e 4 fêmeas), os indivíduos adultos foram mais freqüentes durante a chuvosa-quente, com apenas um jovem capturado na seca-fria; por outro lado, os exemplares de Oxymycterus nasutus ( 3 machos e 2 fêmeas) foram todos adultos, ocorrendo somente na seca-fria. Nesta estação, foram ainda capturados adultos de Euryzygomatomys spinosus (macho e fêmea), 1 macho de Oryzomys ratticeps, bem como adultos e jovens de Oligoryzomys nigripes ( 8 machos e 5 fêmeas). Cavia aperea, representada por uma fêmea adulta, bem como um macho adulto de Rattus norvegicus, foram capturados 
respectivamente, em (Fevereiro, 1995 e Fevereiro/1996) na estaçăo chuvosaquente.

A maior riqueza de espécies ocorreu em Julho/1995 e em Maio/1996, durante a estação seca-fria. Em ambos meses foram capturadas quatro espécies: Bolomys lasiurus, Oxymycterus nasutus e Oligoryzomys nigripes, sendo Oxymycterus hispidus e Euryzygomatomys spinosus capturados em Julho/1995 e Maio/1996, respectivamente. Nestes meses de maior riqueza, Akodon cursor esteve ausente.

\section{III.2. Material microbiológico}

As culturas positivas para crescimento de espiroquetas tanto no sangue dos marsupiais como nos carrapatos coletados nestes mamíferos, segundo os meses e os pontos de coletas estão relacionadas na Tabela 9. Houve crescimento de espiroquetas em $13 \%$ das culturas de sangue de $D$. marsupialis (8/61). Os gambás D3, D6 e D7, foram capturados mais de uma vez mas apresentaram infecção com espiroquetas somente na primeira captura. Todos os marsupiais eram adultos $\theta$ ambos os sexos foram igualmente infectados. Destacou-se em negrito quando ambos marsupiais e carrapatos, apresentaramse infectados com espiroquetas.

Os carrapatos infectados com espiroquetas e não infectados, colhidos mensalmente nos marsupiais, segundo as espécies, sexo e estágio biológico, podem ser verificados na Tabela 10. A porcentagem de carrapatos infectados com espiroquetas representou $36.4 \%$ do total, sendo que a maior porcentagem de infectados foi verificada em Janeiro/1995. Machos de 1. didelphidis foram mais infectados que fêmeas, enquanto que as fêmeas de $I$. loricatus foram mais infectadas que machos.

As proporçőes de carrapatos infectados e não infectados entre machos, fêmeas e imaturos estão estăo ilustradas na Figura 22. As fêmeas de ambas as espécies estavam totalmente ingurgitadas, bem como os carrapatos imaturos de Ixodes sp. 
Tabela 9. Marsupiais e carrapatos coletados entre Janeiro/1995 e Junho/1996, em Itapevi, SP, que apresentaram crescimento de espiroquetas em culturas.

\begin{tabular}{|c|c|c|c|c|c|c|c|}
\hline \multirow[b]{2}{*}{ Meses } & \multirow[b]{2}{*}{$\mathbf{P}$} & \multicolumn{2}{|c|}{ D. marsupialis ( $\mathrm{N}=61$ ) } & \multicolumn{4}{|c|}{ Carrapatos de Marsupiais ( $\mathrm{N}=55$ ) } \\
\hline & & Animais/Sexo & Sangue & I. didelphidis & 1. Ioricatus & Ixodes sp. & A. cajennense \\
\hline Jan/95 & 1 & D1/M & + & - & + & - & - \\
\hline Jan/95 & 1 & $D 2 / F$ & - & + & - & - & - \\
\hline Fev/95 & 2 & D3/F & + & - & - & - & - \\
\hline Fev/95 & 2 & D6/F & + & + & - & - & - \\
\hline Fev/95 & 2 & D7M & + & - & - & - & - \\
\hline Mar/95 & 3 & $D 7 / M$ & - & + & - & - & - \\
\hline Mar/95 & 3 & $\mathrm{D} 10 / \mathrm{F}$ & + & - & - & - & - \\
\hline Abr/95 & 4 & - & - & - & - & - & - \\
\hline Mai/95 & $5 a$ & D17/M & + & - & + & - & - \\
\hline Jun/95 & 6 & - & - & - & - & - & - \\
\hline Ju//95 & 7 & . & - & - & - & - & - \\
\hline Ago/95 & 8 & - & - & - & - & - & - \\
\hline Set/95 & 9 & - & - & - & - & - & - \\
\hline Out/95 & $10 \mathrm{a}$ & $\mathrm{D} 31 / \mathrm{F}$ & + & - & - & - & - \\
\hline Nov/95 & $11 \mathrm{c}$ & $D 6 / F$ & - & - & + & - & - \\
\hline Dez/95 & 12 & - & - & - & - & - & - \\
\hline Jan/96 & $13 b$ & $\mathrm{D} 36 / \mathrm{F}$ & - & + & - & - & - \\
\hline Fev/96 & $14 \mathrm{~b}$ & D38/M & - & + & - & - & - \\
\hline Mar/96 & $15 a$ & D39/M & - & - & - & - & + \\
\hline Abr/96 & $16 a$ & D41/M & + & - & + & + & - \\
\hline Abr/96 & $16 a$ & D44/F & - & - & + & - & - \\
\hline Mai/96 & $17 \mathrm{~b}$ & $\mathrm{D} 46 / \mathrm{M}$ & - & + & - & - & - \\
\hline Jun/96 & $18 \mathrm{~b}$ & D50/F & - & + & - & - & - \\
\hline
\end{tabular}

Destacados em negrito quando ambos, $D$. marsupialis e carrapatos, apresentaram-se infectados; $M$, macho $F$, fêmea; P, pontos de coletas esquematizados na Figura $2 ; D, n^{\circ}$ de campo do individuo; $N$, número d exemplares investigados. 
Tabela 10. Número de carrapatos infectados com espiroquetas e năo infectados, segune as espécies, sexo e estágio biológico, coletados mensalmente em marsupia entre Janeiro/1995 e Junho/1996, em Itapevi, SP, e porcentagem de infectado

\begin{tabular}{|c|c|c|c|c|c|c|c|c|}
\hline \multirow[b]{3}{*}{ Meses } & \multicolumn{2}{|c|}{ L.didelphidis } & \multicolumn{2}{|c|}{ 1. Ionicatus } & \multicolumn{2}{|c|}{ Ixodes sp. } & \multirow{3}{*}{$\begin{array}{c}\text { A. cajennense } \\
\text { Fếmea } \\
N\left(N^{\circ}\right) \\
\end{array}$} & \multirow[b]{2}{*}{ Total } \\
\hline & Macho & Fêmea & Macho & Fêmea & Ninfa & Larva & & \\
\hline & $N\left(N^{\circ}\right)$ & $N\left(N^{0}\right)$ & $N\left(N^{0}\right)$ & $N\left(N^{\circ}\right)$ & $N\left(N^{0}\right)$ & $N\left(N^{0}\right)$ & & $N\left(N^{0}-\%\right)$ \\
\hline Jan/95 & $1(1)$ & - & $4(1)$ & $9(3)$ & $1(0)$ & - & - & $15(5-33.3)$ \\
\hline Fev/95 & $1(1)$ & $1(0)$ & - & - & - & - & - & $2(1-50.0)$ \\
\hline Mar/95 & $3(2)$ & $2(1)$ & - & - & - & - & - & $5(3-60.0)$ \\
\hline Abr/95 & - & $1(0)$ & - & - & - & - & - & $1(0)$ \\
\hline Mai/95 & - & - & - & $1(1)$ & - & - & - & $1(1-100.0)$ \\
\hline Jun/95 & - & - & - & - & - & - & - & - \\
\hline Jul/95 & - & - & - & - & - & $3(0)$ & - & $3(0)$ \\
\hline Ago/95 & - & - & - & $1(0)$ & - & - & - & $1(0)$ \\
\hline Set/95 & - & - & - & $4(0)$ & $3(0)$ & - & - & $7(0)$ \\
\hline Out/95 & - & - & - & - & - & - & - & - \\
\hline Nov/95 & - & - & - & $4(1)$ & - & - & - & $4(1-25.0)$ \\
\hline Dez/95 & - & - & - & $1(0)$ & - & - & - & $1(0)$ \\
\hline Jan/96 & $1(1)$ & - & - & - & - & - & - & $1(1-100.0)$ \\
\hline Fev/96 & $1(1)$ & - & - & - & - & - & - & $1(1-100.0)$ \\
\hline Mar/96 & $2(0)$ & - & - & - & - & - & $1(1)$ & $3(1-33.3)$ \\
\hline Abr/96 & - & $1(0)$ & - & $2(2)$ & $1(1)$ & $1(1)$ & - & $5(4-80.0)$ \\
\hline Mai/96 & $1(1)$ & - & - & - & - & - & - & $1(1-100.0)$ \\
\hline Jun/96 & $3(1)$ & $1(0)$ & - & - & - & - & - & $4(1-25.0)$ \\
\hline Total & $13(8)$ & $6(1)$ & $4(1)$ & $22(7)$ & $5(1)$ & $4(1)$ & $1(1)$ & $55(20-36.4)$ \\
\hline
\end{tabular}

Espécimens infectados entre parênteses; $M$, macho; $F$, fêmea; $N$, ninfa; $L$, larva 


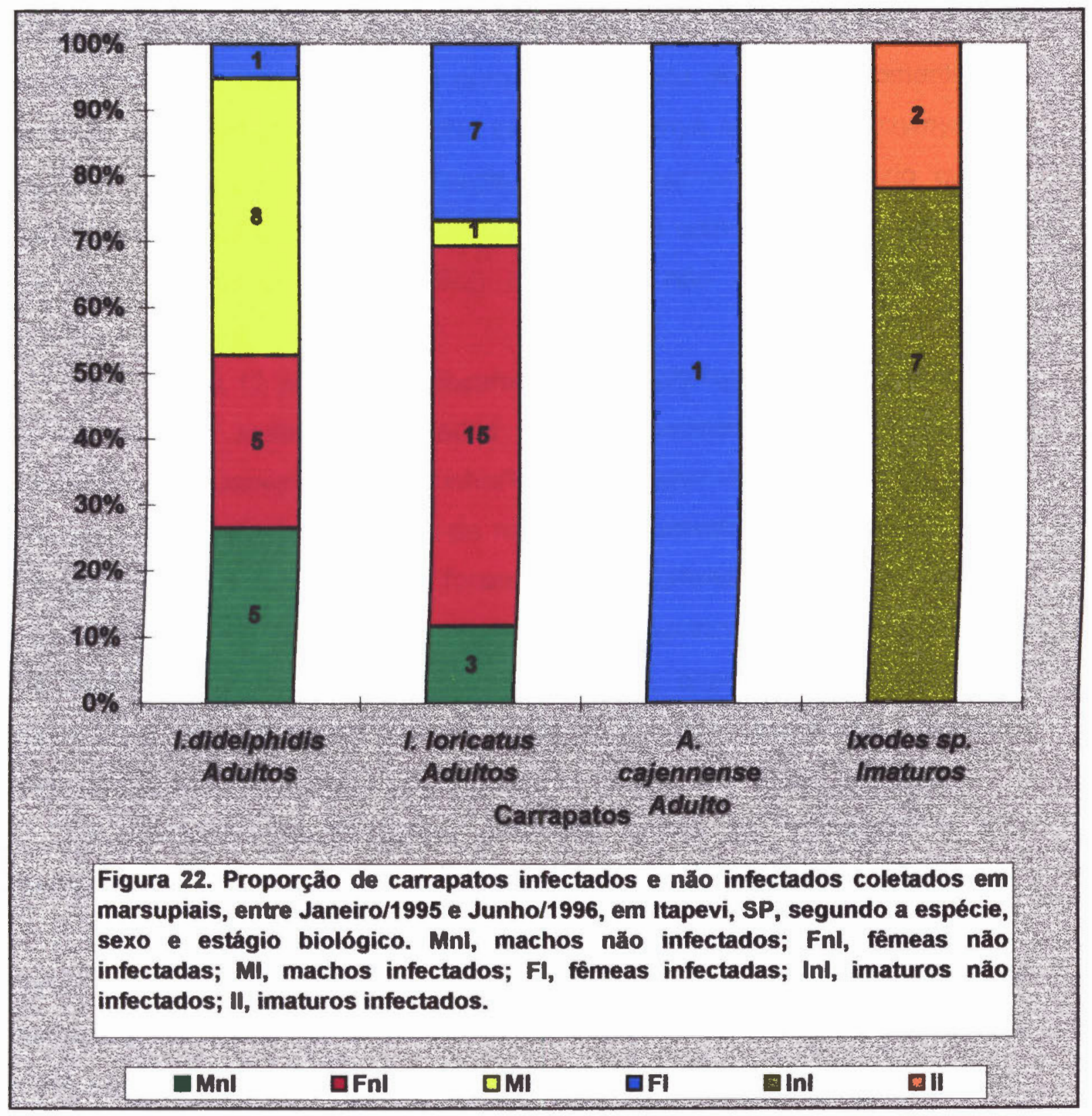


Os roedores positivos para espiroquetas em culturas de sangue e órgãos, segundo os meses a pontos de coletas esquematizados na Figura 2, estăo representados na Tabela 11. A freqüéncia de individuos infectados, tanto sangue quanto órgãos, representou $9.7 \%$ do total de roedores examinados (7/2), sendo que todos as indivíduos infectados eram adultos. Dentre as nove espécies de roedores capturadas durante o periodo de estudo, somente três espécies representadas por Akodon cursor, Bolomys lasiurus e Oxymycterus hispidus (Figura 23), estavam infectadas com espiroquetas, sendo que os indivíduos infectados năo apresentaram infestação com carrapatos, exceto um exemplar de Akodon cursor (DR2) cuja larva năo estava infectada com espiroquetas.

$\mathrm{Na}$ Tabela 12 podem ser observados os roedores que foram infestados com carrapatos imaturos infectados e não infectados com espiroquetas, coletados entre Janeiro/1995 e Junho/1996, nos respectivos pontos de coletas indicados na Figura 2. A espécie de roedor mais infestada com carrapatos foi Oligoryzomys nigripes; entretanto, foram somente coletados carrapatos positivos em apenas 2 hospedeiros adultos capturados em Agosto/1995 no ponto 8b. Nos dois individuos jovens de B. lasiurus infestados, capturados em Maio/1996 (ponto 17 a), os carrapatos estavam positivos. Em três exemplares infestados de $A$. cursor, dois adultos e um jovem, todos os carrapatos foram negativos.

A proporção de carrapatos imaturos lxodes sp. infectados e não infectados colhidos nestes roedores, está demonstrada na Figura 24.

O número de mamíferos e carrapatos coletados e a porcentagem de infectados com espiroquetas, em relação às estações sazonais, podem ser observados na Figura 25. As mais altas porcentagens de exemplares infectados foram observadas na estação chuvosa-quente, com exceção de carrapatos infectados coletados em roedores.

Em microscopia de campo escuro (aumento de $1000 \mathrm{X}$ ), as espiroquetas observadas nas culturas de sangue dos mamíferos e carrapatos (Figura 26a e b, respectivamente) mostram-se semelhantes morfologicamente. Porém săo 
Tabela 11. Espécies de roedores coletadas entre Janeiro/1995 e Junho/1996, om Itapevl, SP, que apresentaram espiroquetas em culturas de sangue o orgăos.

\begin{tabular}{|c|c|c|c|c|c|c|c|c|}
\hline \multirow[b]{2}{*}{ Meses } & \multirow[b]{2}{*}{$\mathbf{P}$} & \multicolumn{7}{|c|}{ Roedores ( $N=72$ ) } \\
\hline & & Espécie/Sexo & DR & Sangue & Bexiga & RIm & Baço & Figado \\
\hline Mar/95 & 3 & Oxymycterus hispidus $M$ & DR1 & + & - & - & - & - \\
\hline Abr/95 & $4 a$ & Axodon cursor/M & DR2 & + & - & - & + & - \\
\hline Abr/95 & $4 a$ & A. cursor/F & DR3 & - & - & - & + & - \\
\hline Abr/95 & $4 a$ & Bolomys lasiurus/F & DR4 & - & - & - & + & - \\
\hline Jan/96 & $13 a$ & A. cursor/F & DR52 & - & + & - & - & - \\
\hline $\operatorname{Jan} / 98$ & $13 a$ & O. hispidus $M$ & DR53 & - & - & + & - & + \\
\hline Fev/98 & $14 a$ & O. hispidus /F & DR57 & - & - & - & - & + \\
\hline
\end{tabular}

N, número de exemplares examinados; $M$, macho; F, femea; DR, número de campo do indivíduo;

$P$, pontos de coletas esquematizados na Figura 2. 


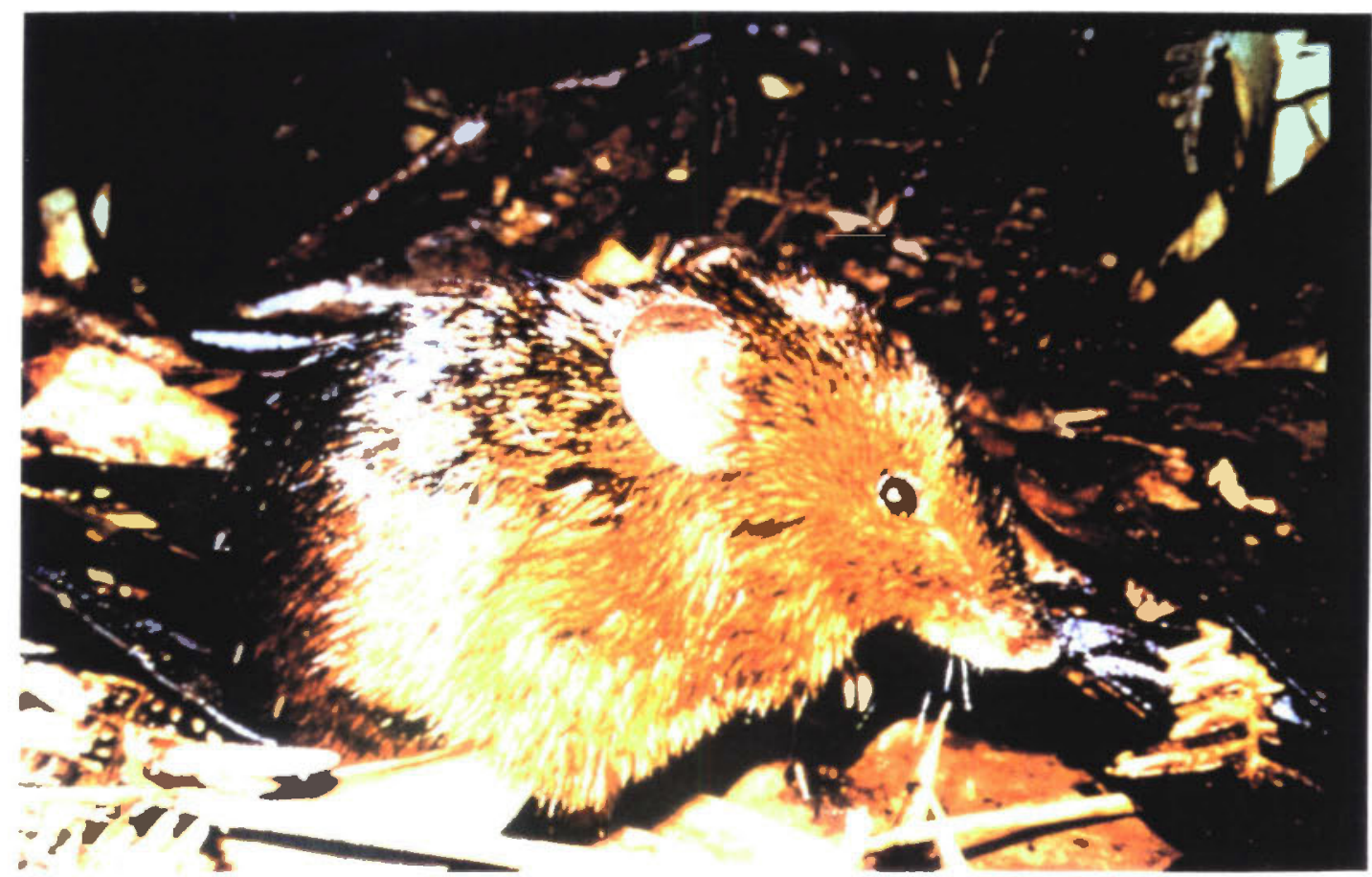

Figura 23. Oxymycterus hispidus (Muridae: Rodentia), capturado em Itapevi, SP. 
Tabela 12. Número de carrapatos imaturos Ixodes sp. infectados e não infectados coletados em roedores, entre Janeiro/1995 e Junho/1996, em Itapevi, SP.

\begin{tabular}{|c|c|c|c|c|c|c|c|}
\hline \multirow[b]{2}{*}{ Meses } & \multirow[b]{2}{*}{$P$} & \multicolumn{2}{|c|}{ Roedores Infestados } & \multicolumn{2}{|c|}{ Larvas de lxodes sp. } & \multicolumn{2}{|c|}{ Ninfas de lxodes sp. } \\
\hline & & Espécie/DR & Idade/Sexo & Examinadas & Infectadas & Examinadas & Infectadas \\
\hline Abr/95 & $4 a$ & A.cursor/DR2 & Adulto/M & 1 & 0 & 0 & 0 \\
\hline Ago/95 & $8 \mathrm{~b}$ & A.cursor/DR32 & Adulto/M & 0 & 0 & 1 & 0 \\
\hline Ago/95 & $8 b$ & O.nigripes /DR28 & Adulto/M & 2 & 0 & 2 & 0 \\
\hline Ago/95 & $8 b$ & O. nigripes /DR29 & Adulto/M & 1 & 0 & 2 & 0 \\
\hline Ago/95 & $8 b$ & O.nigripes/DR30 & Aduito/F & 1 & 1 & 2 & 1 \\
\hline Ago/95 & $8 b$ & O.nigripes /DR31 & Adulto/M & 2 & 1 & 5 & 4 \\
\hline Ago/95 & $8 b$ & O.nigripes /DR33 & Adulto/M & 1 & 0 & 3 & 0 \\
\hline Ago/95 & $8 b$ & O. nignipes /DR34 & Adulto/F & 1 & 0 & 2 & 0 \\
\hline Ago/95 & $8 b$ & O.nigripes /DR35 & Jovem/M & 1 & 0 & 1 & 0 \\
\hline Set/95 & $9 a$ & O. nigripes /DR40 & Adulto/M & 1 & 0 & 0 & 0 \\
\hline Out/95 & $10 a$ & A.cursor/DR43 & Jovem $/ M$ & 0 & 0 & 1 & 0 \\
\hline Mai/96 & $17 a$ & B.lasiurus /DR61 & Jovem $/ M$ & 1 & 1 & 0 & 0 \\
\hline Mai/96 & $17 a$ & B. lasiurus/DR66 & Jovem/M & 2 & 2 & 0 & 0 \\
\hline
\end{tabular}

$P$, pontos de coletas esquematizados na Figura 2; $D R$, número do individuo; $M$, macho; $F$, fêmea. Destacados em negrito o número de carrapatos infectados. 


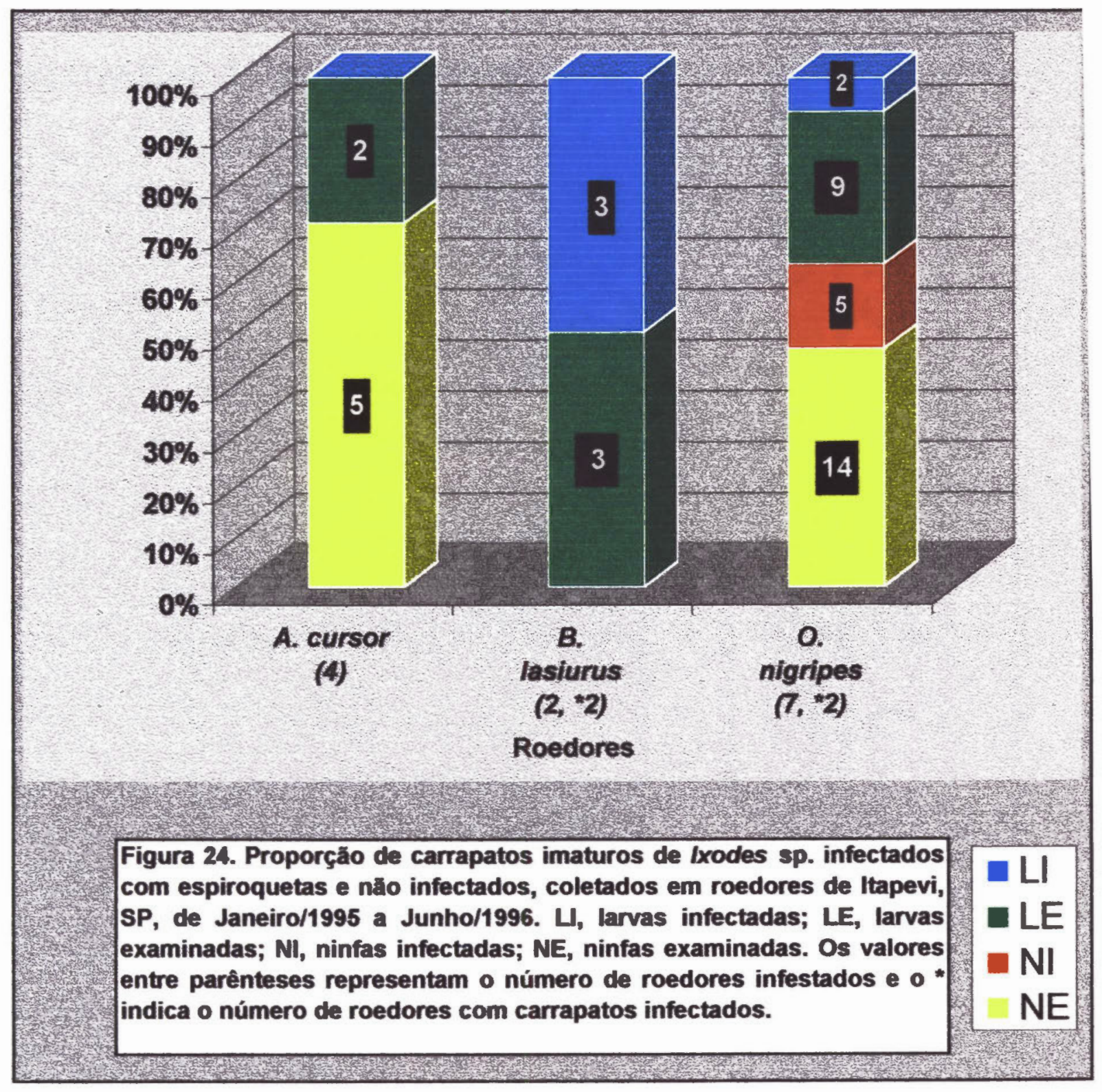




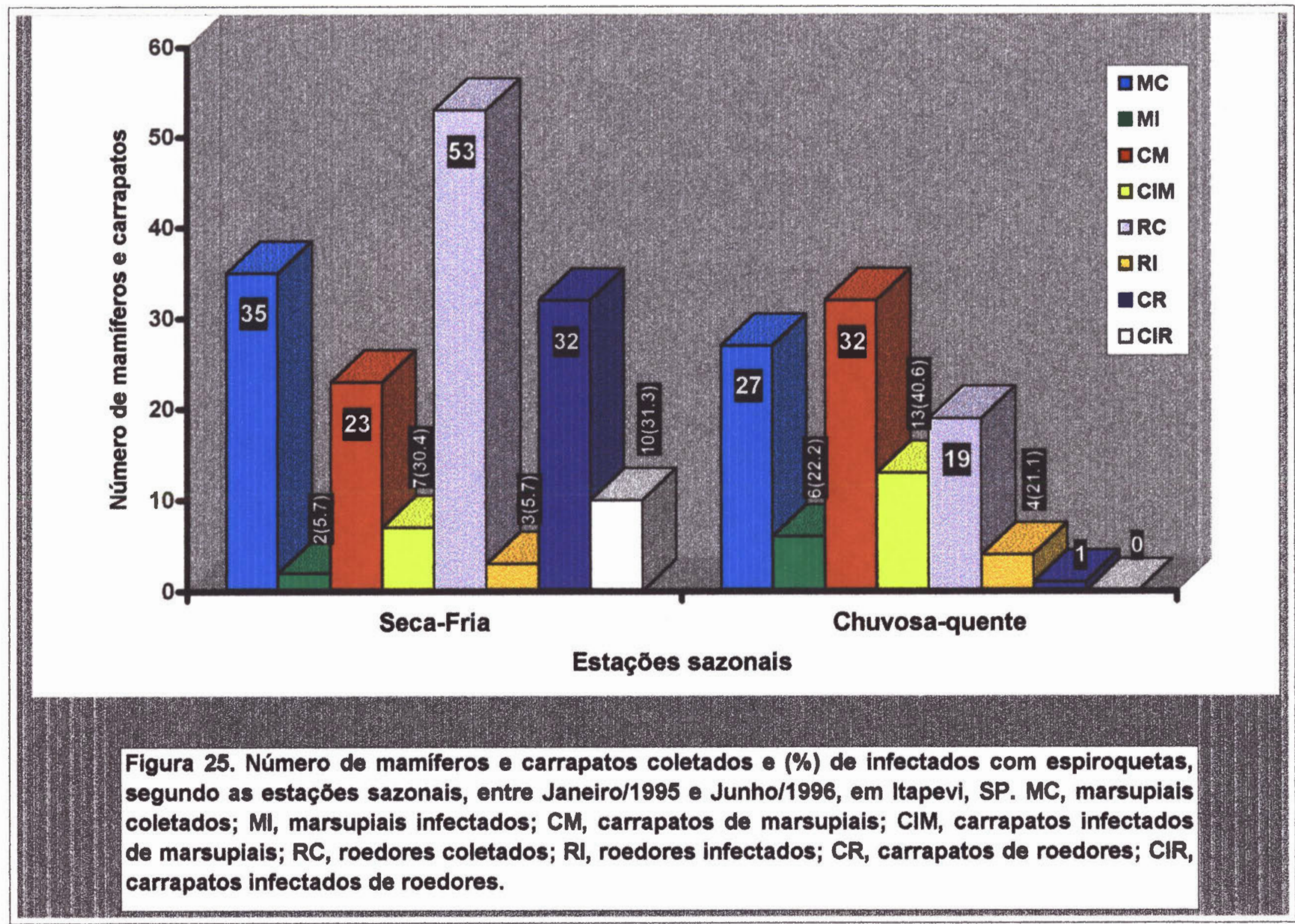



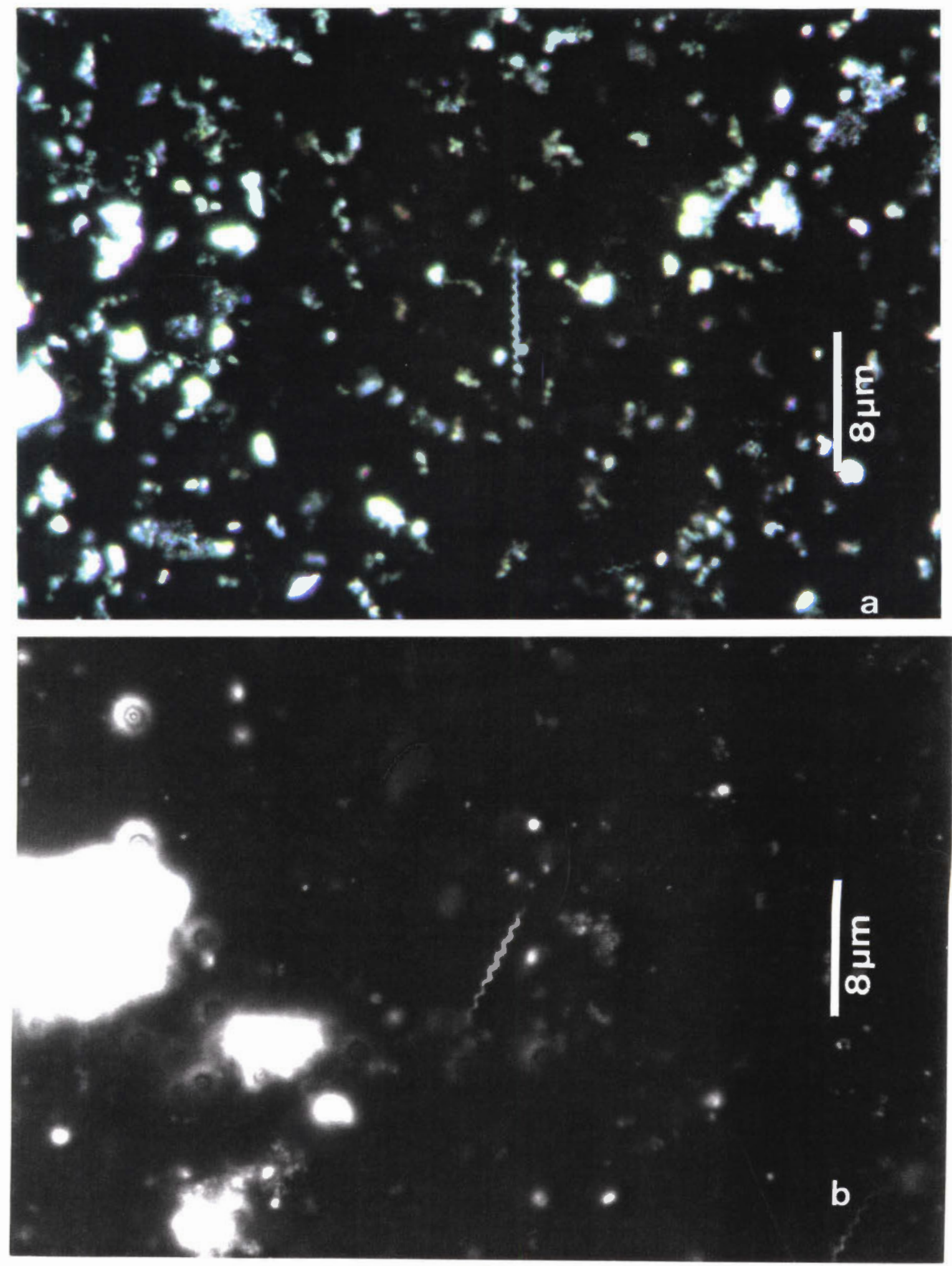

Figura 26. Espiroquetas fotografadas em microscópio de campo escuro $(1000 X)$ obtidas no presente estudo. a) em cultura de sangue de pequenos mamíferos; b) em cultura de carrapatos. 
mais delgadas e com maior número de espiras, quando comparadas com a cepa americana G39/40 de Borrelia burgdorferi (Figura 27), cedida pelo Dr. Allen C. Steere e com as cepas européias de B. garinii (Figura 28) e B. afzelii (Figura 29), ambas trazidas da Alemanha pela Dra. Sonia Regina Pinheiro e cedidas pelo Dr. Arno A. Gustav Schonberg.

Os esfregaços de culturas positivas tanto de sangue como de carrapatos colhidos nos animais, coraram-se perfeitamente com fontana (Figura 30a e b, respectivamente). Entretanto, em esfregaços de sangue dos marsupiais e roedores e "in print" de ógãos dos roedores corados com Giemsa, a morfologia das espiroquetas variou em comprimento, dependendo do órgăo, sendo menores em rim e baço (Figura $31 \mathrm{a}$ e $\mathrm{b}$ ) quando comparadas com aquelas do sangue (Figura 32), bexiga e figado (Figura 33a, b, respectivamente).

Animais e carrapatos infectados com espiroquetas foram coletados em quase todos os meses de estudo, excetuando os meses de Julho (ponto $7 a, b$ ) durante a estação seca-fria, Setembro (ponto $9 a, b, c$ ) final da estaçăo seca-fria e Dezembro/1995 (ponto 12a, b) durante a estação chuvosa-quente.

Os pontos onde os animais e carrapatos coletados apresentaram culturas positivas para espiroquetas, foram assinalados com um círculo, conforme demonstra a Figura 34. Exatamente no ponto 4a indicado por uma flecha curva, está localizada a residéncia dos dois meninos que adquiriram a doença, em 1992, após terem sido picados por carrapatos quando brincavam no quintal e arredores. Estes, foram considerados os primeiros casos diagnosticados no Brasil com sorologia positiva e quadro clínico compativel com a doença de Lyme. 


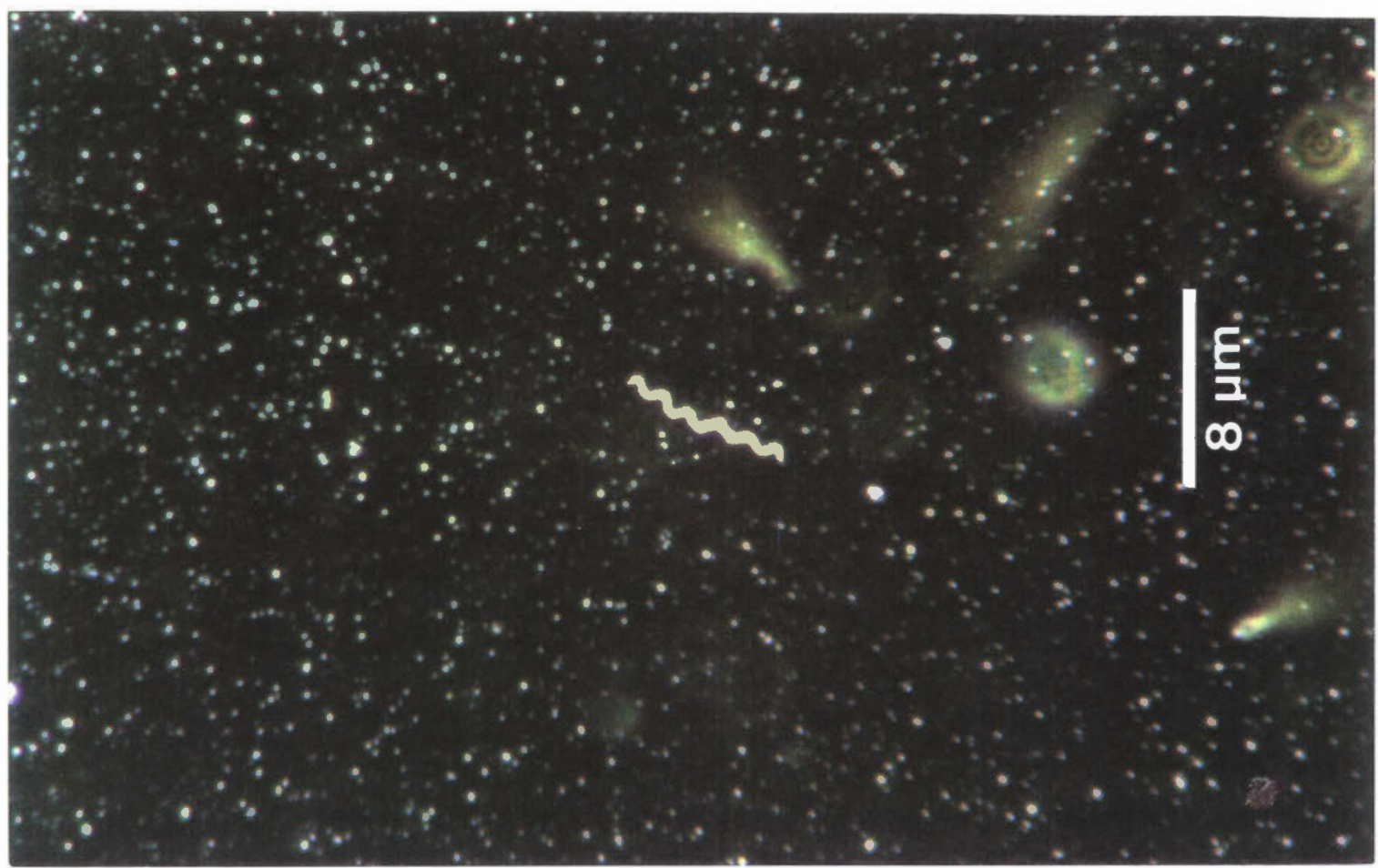

Figura 27. Borrelia burgdorferi (Spirochaetaceae: Spirochaetales) cepa americana, fotografada em microscópio de campo escuro (1000 X).

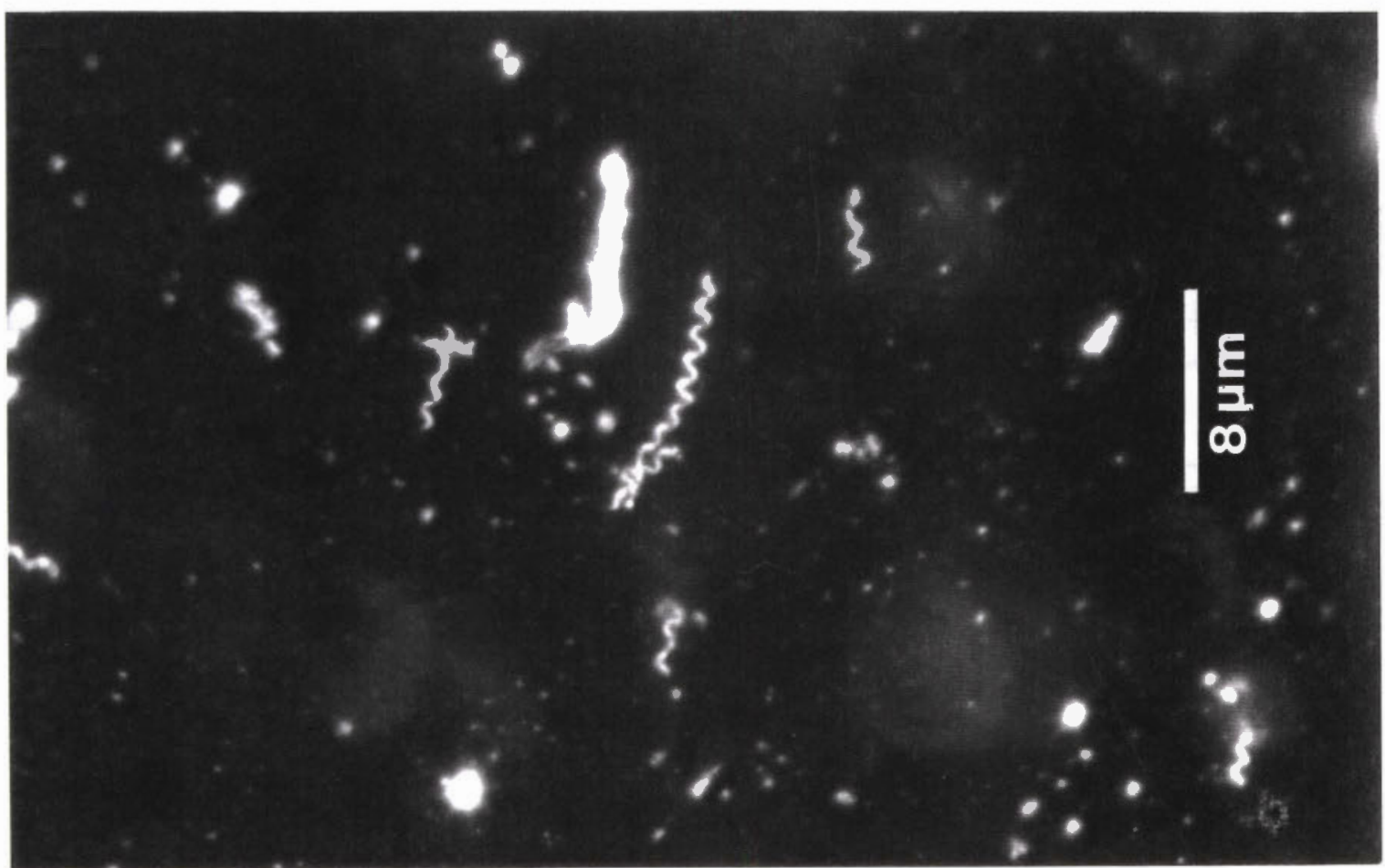

Figura 28. Borrelia garinii (Spirochaetaceae: Spirochaetales) cepa européia, fotografada em microscópio de campo escuro (1000 X). 


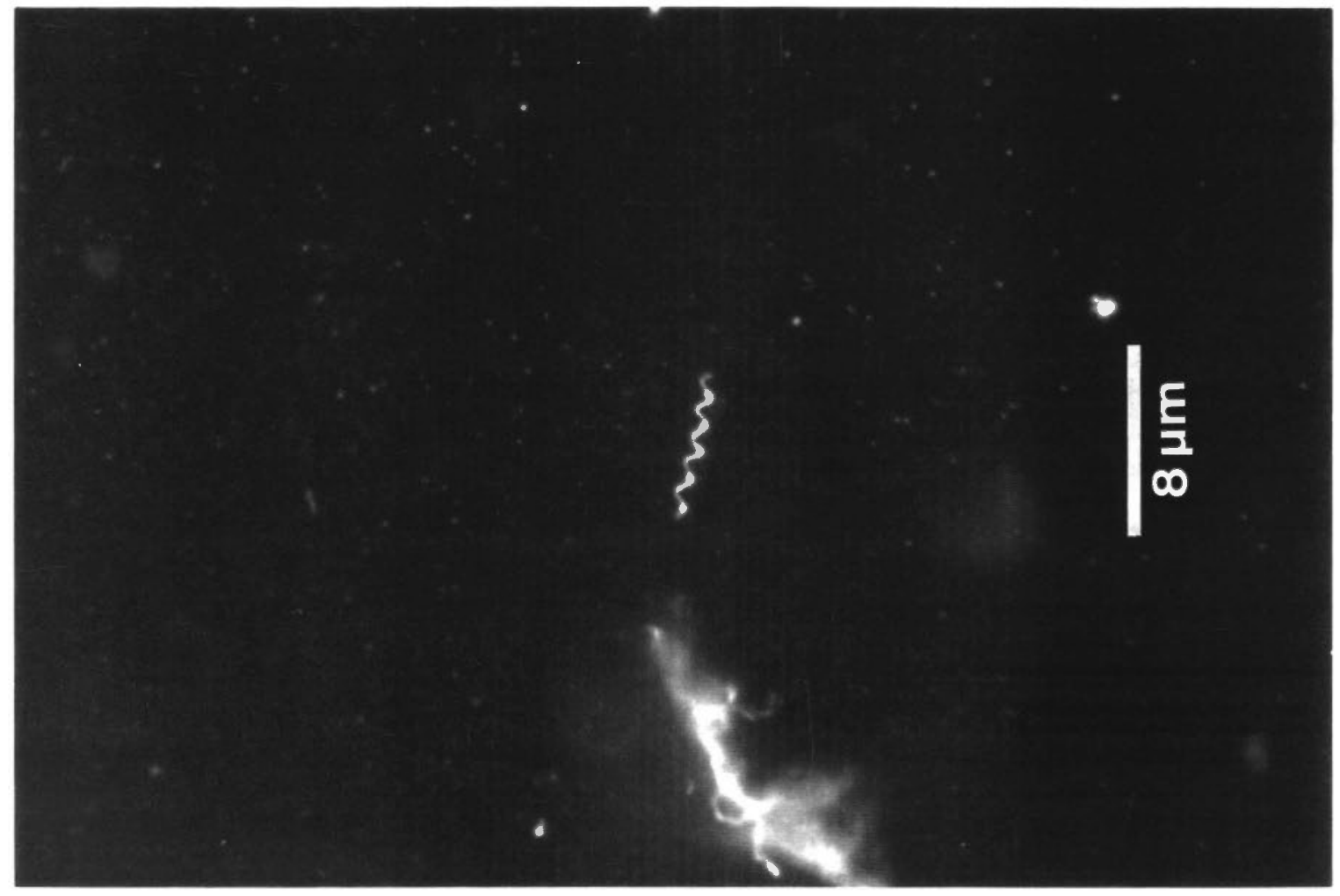

Figura 29. Borrelia afzelii (Spirochaetaceae: Spirochaetales) cepa européia, fotografada em microscópio de campo escuro (1000 X). 


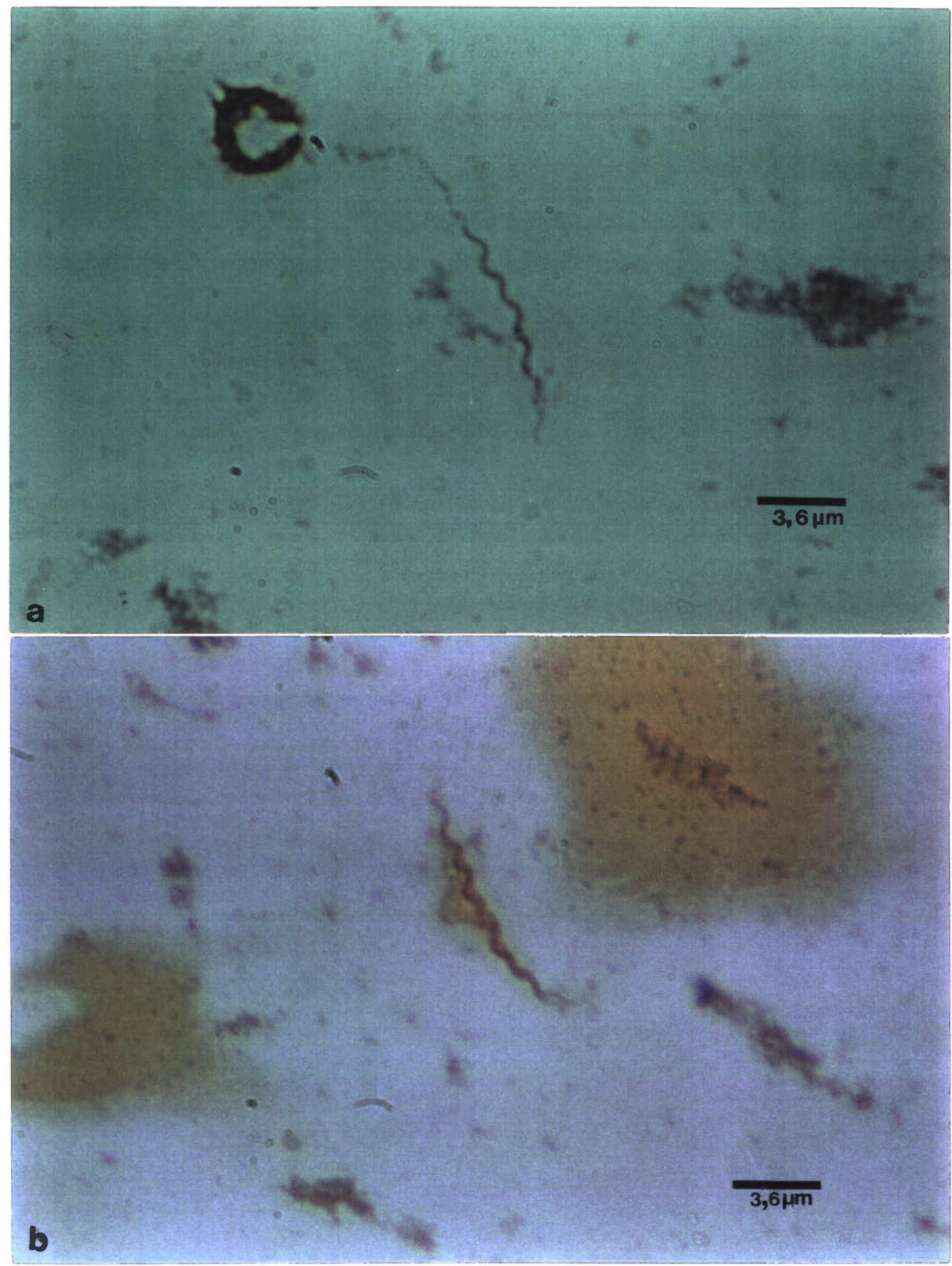

Figura 30. Espiroquetas em esfregaços de culturas positivas corados com Fontana-Tribondeau (1260 X) obtidas no presente estudo. a) cultura de sangue de pequenos mamiferos; b) cultura de carrapatos. 

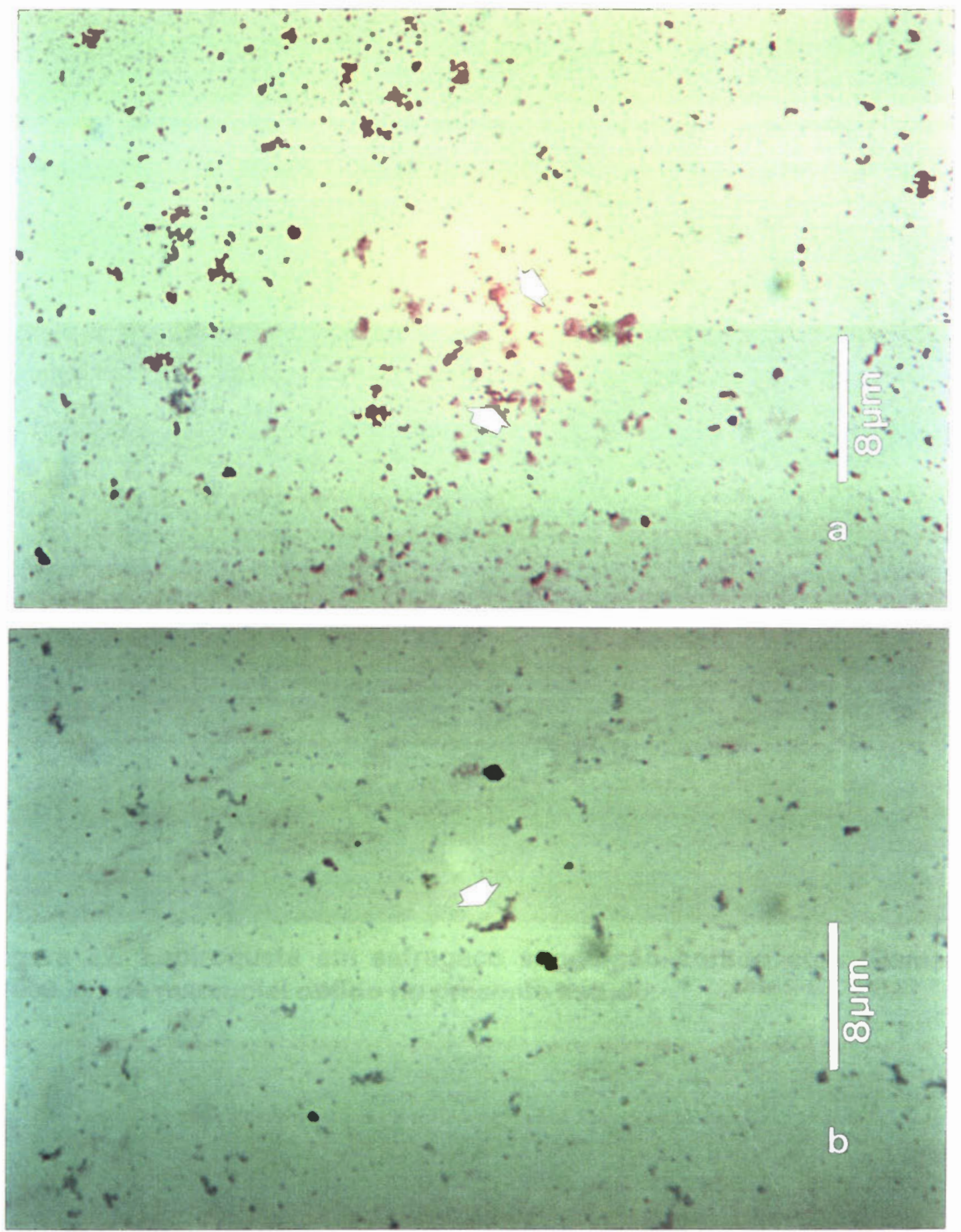

Figura 31. Espiroquetas coradas com Giemsa em "in print" de órgãos de roedores obtidos no presente estudo (1000 X). a) rim; b) baço. 


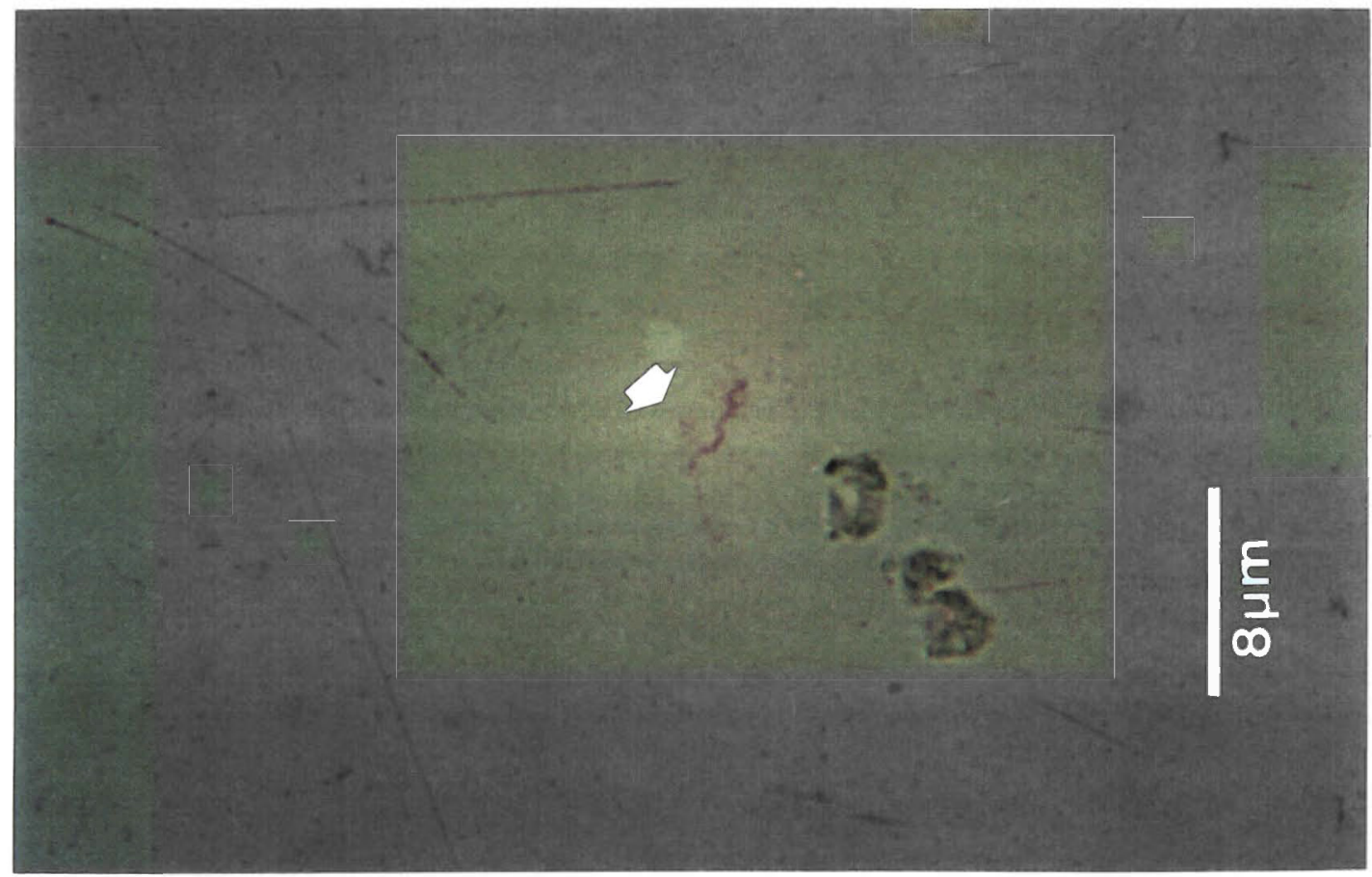

Figura 32. Espiroqueta em esfregaço sangüíneo corado com Giemsa $(1000 \mathrm{X})$, de marsupial obtido no presente estudo. 

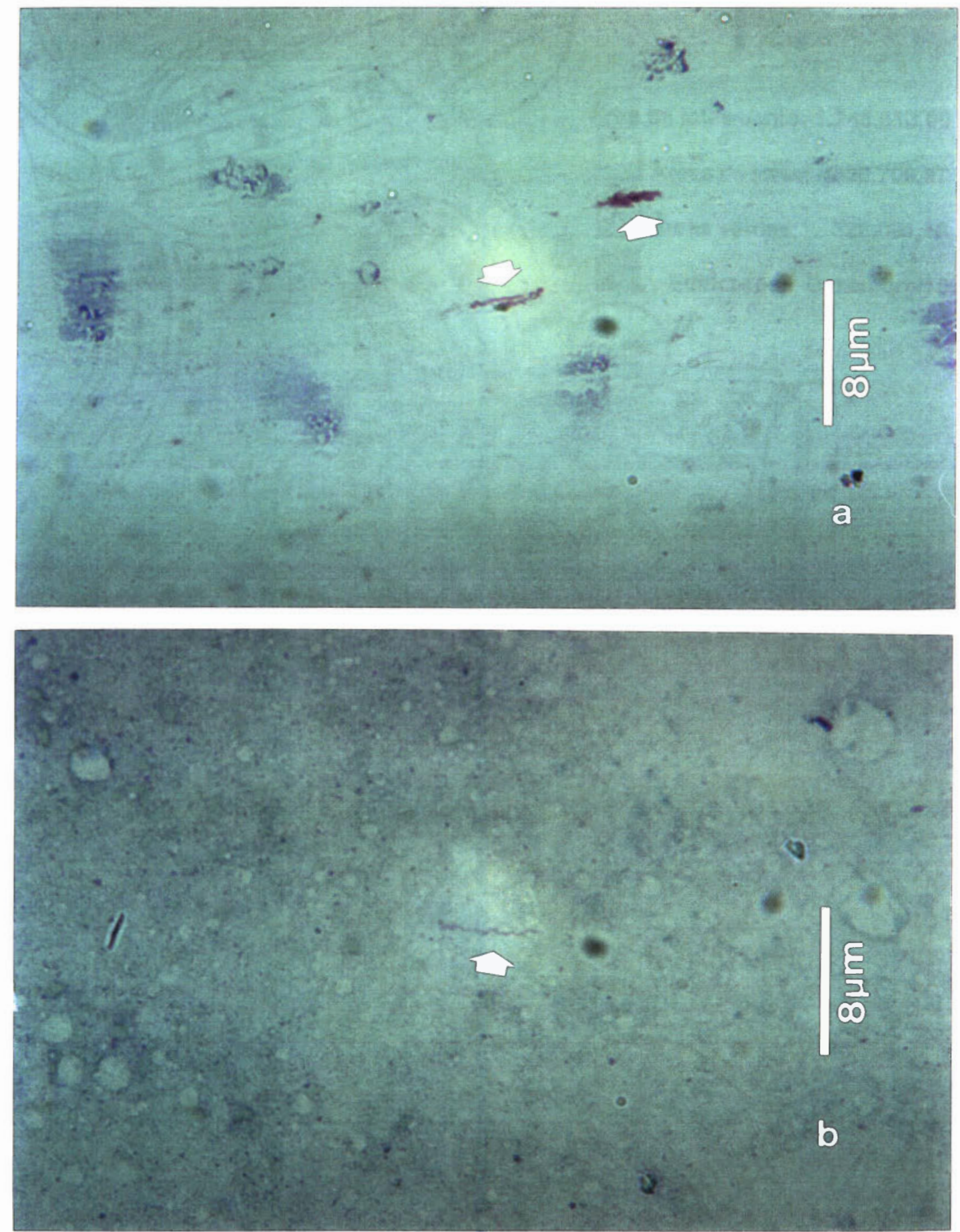

Figura 33. Espiroquetas coradas com Giemsa em "in print" de órgãos de roedores obtidos no presente estudo (1000 X). a) bexiga; b) figado. 


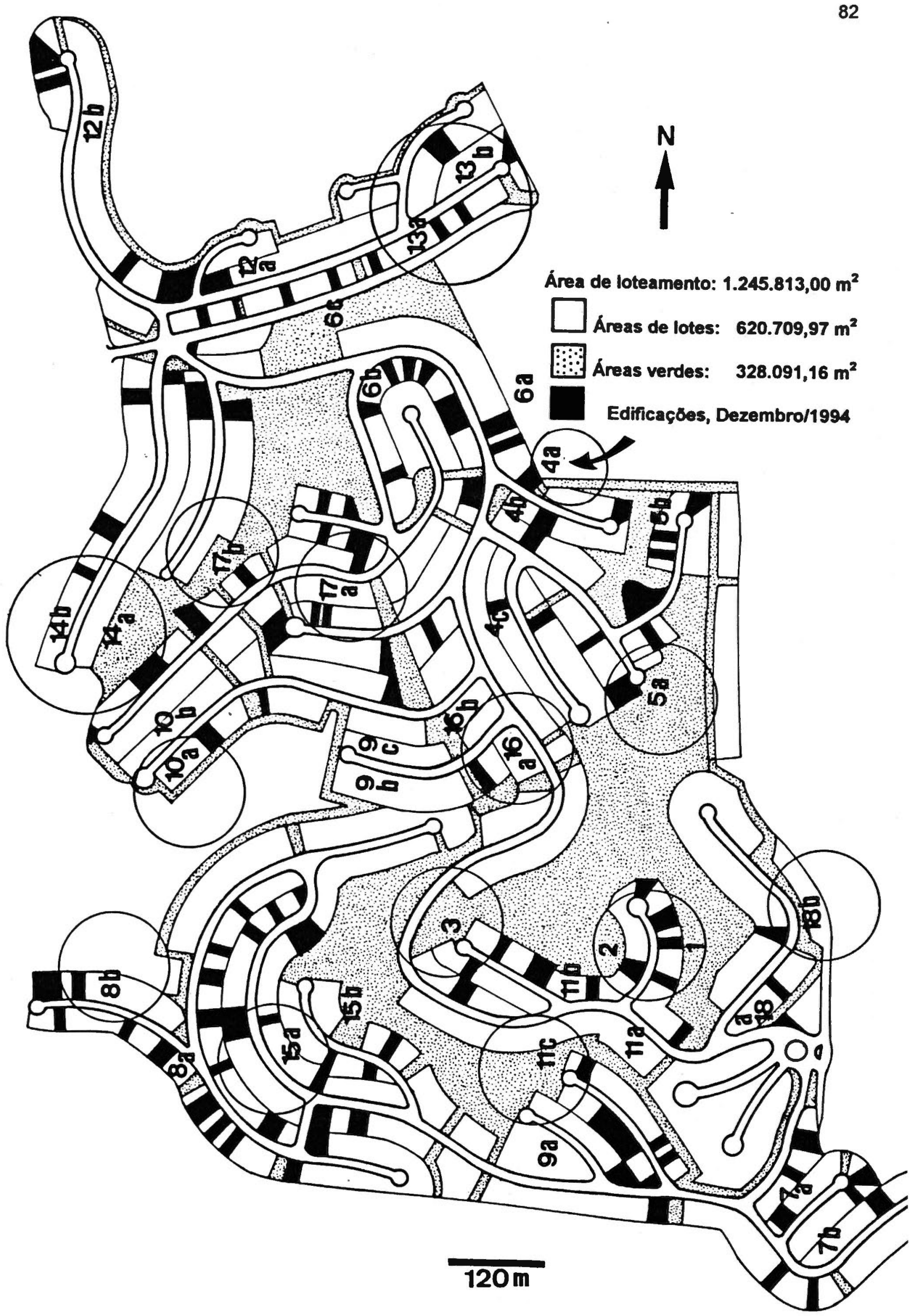

Figura 34. Locais assinalados com um círculo onde os mamíferos e carrapatos coletados mensalmente, entre Janeiro/1995 e Junho/1996, estavam infectados com espiroquetas. A flecha indica a localização onde dois meninos contrairam doença de Lyme em 1992, após terem sido picados por carrapatos. 


\section{DISCUSSÃO}

\section{Vl.1. Consideraçర̋es bioecológicas de carrapatos e pequenos mamiferos}

O carater de diferenciação morfológica das placas peritremais entre as espécies I. didelphidis e I. loricatus (Figuras $5 a$ e b, $7 a$ e b), precisaria ser melhor investigado pois, pode tratar-se de variação intraespecífica como foi observado por Fairchild et al. (1966). Entretanto, somente os estudos de biologia tradicional em laboratório, em conjunto com a biologia molecular, poderiam esclarecer a dúvida sobre a validade destas espécies. A análise de DNA mitocondrial entre grupos de espécies próximas, cujos resultados evidenciam a posiçăo taxonômica, tem contribuido substancialmente para a determinação de sinonímias (Norris et al., 1997). Todavia, enquanto as dúvidas taxonômicas não forem esclarecidas, ambas as espécies são consideradas válidas enquanto não forem sinonimizadas, sendo portanto, abordadas no presente estudo, como espécies distintas pertencentes ao complexo I. ricinus (Clifford et al., 1973). Embora os estágios imaturos não tenham sido identificados ao nivel específico, as ninfas apresentaram alguns dos caracteres descritos por Cooley \& Kohls (1945) para I. loricatus. Em vista ventral, a base do capítulo é alongada, com bordos arredondados e com largas extensões laterais que possivelmente vão originar as aurículas; hipostômio longo, arredondado apicalmente, dentiçăo $2 / 2 \mathrm{com}$ os dentes laterais maiores que os medianos; placa espiracular ovalada, com mácula central e apenas poucos glomérulos distribuídos irregularmente. Devido à insegurança quanto à determinação especifica para os carrapatos imaturos, preferiu-se utilizar somente o taxon genérico.

Os carrapatos I. didelphidis $\Theta I$. loricatus no estágio adulto, bem como os estágios imaturos de Ixodes $\mathrm{sp}$. foram responsáveis pelo parasitismo em $19.4 \%$ dos marsupiais e $9.7 \%$ dos roedores, totalizando $29.1 \%$ de hospedeiros 
infestados (Tabela I). Os roedores silvestres foram parasitados somente por carrapatos imaturos de lxodes sp., enquanto os marsupiais foram infestados com a totalidade de carrapatos adultos e alguns poucos exemplares de imaturos. Estes dados, vèm confirmar os poucos relatos da literatura sobre $l$. loricatus e I. didelphidis, com relaçăo às preferências pelo hospedeiro, conforme os diferentes estágios biológicos (Aragão, 1936; Cooley \& Kohls, 1945; Ribeiro, 1966/1967). Além disso, estes dados vêm somar-se àqueles obtidos sobre hospedeiros e distribuiçăo geográfica para as espécies brasileiras de Ixodes depositadas na coleção acarológica do Instituto Butantan (Barros-Battesti \& Knysak, 1998).

Em outras regiões brasileiras, onde foram realizados estudos de ectoparasitofauna de pequenos mamíferos em área com vegetaçăo secundária de Mata Atlântica, os carrapatos do gènero /xodes são encontrados infestando uma porcentagem menor de pequenos mamíferos. Assim, a porcentagem de roedores infestados com 1. amarali em Belo Horizonte, MG, foi 3.5\% (Linardi et al., 1984) e, em Tiradentes, MG, foi $0.8 \%$ para Ixodes sp. (Lopes et al., 1989).

Embora Guitton et al. (1986) não tenham expressado o número de hospedeiros infestados, estes autores encontraram seis exemplares das espécies 1. amarali e I. loricatus num total de 126 pequenos mamiferos capturados. Comparando estas porcentagens com aquela obtida no presente estudo (Tabela I), verifica-se que as matas do condomínio Transurb apresentam condiçōes favoráveis ao desenvolvimento biológico das espécies de Ixodes encontradas, considerando a quantidade média mensal de pequenos mamiferos capturados nestas áreas (Tabela 3). De fato, houve um bom sucesso de captura de mamíferos $(4.6 \%)$, apesar do pequeno esforço de captura (2888 armadilhas/noite) devido ao número de armadilhas disponiveis.

O presente trabalho foi iniciado com a pretensăo de se coletar por um periodo de 24 meses, para obtenção resultados mês a més que expressassem melhor as correlaçōes entre mamiferos, carrapatos e variáveis meteorológicas, considerando as oscilaçōes climáticas que ocorrem em florestas com clima 
tropical. Entretanto, devido ao alto custo financeiro, optamos por reduzir o período de coletas em 18 meses. Para que a análise mensal dos dados não fosse prejudicada procuramos contornar o problema, acrescentando aos resultados, uma interpretação sazonal.

Quando analisados mensalmente, os maiores números absolutos e indices de densidade relativa para marsupiais (IDRM) e roedores (IDRR), foram registrados respectivamente, em Março/1995 (ponto 3) e Junho/1995 (ponto 6a). O menor número absoluto e o IDRM ocorreram em Fevereiro/1996 (ponto 14b), não havendo capturas de roedores em Janeiro/1995 (ponto 1) e Março/1996 (pontos 15b), cujos indices de densidade relativa foram nulos nestes meses (Tabela 3, Figura 2).

O maior número absoluto de carrapatos coletados foi registrado em Agosto/1995 (ponto 8b), entretanto, o maior IDRC ocorreu em Janeiro/1995 (ponto 1), apesar do baixo número absoluto e densidade relativa de mamíferos na área; por outro lado, quando houve maior número de mamíferos capturados (Junho/1995, pontos 6a, b, c d), o número absoluto e o IDRC foram nulos (Tabela 3, Figura 2).

As variáveis meteorológicas (Tabela 2), correlacionadas mensalmente com os números absolutos de marsupiais e carrapatos, bem como, com os IDRM e IDRC (Tabela 4), não foram significantes. Entretanto, para o número absoluto de roedores capturados, as correlaçőes foram inversas e significantes com a temperatura e pluviometria média mensal e pluviometria acumulada mensal, havendo também correlação inversa significante entre o IDRR e temperatura média mensal e semanal. À medida que os valores de temperatura e pluviometria aumentaram, reduziu o número de roedores capturados, conforme demonstram as linhas de tendència nos diagramas de dispersăo (Figuras 13, 14, 15, 16 e 17).

Quando se analisou a distribuição de mamíferos, segundo as estaçōes sazonais, houve maior porcentagem de mamiferos coletados durante a estação seca-fria em relação a estaçăo chuvosa-quente (Figura 18). A ocorrência de 
flutuaçăo sazonal com um aumento de capturas de pequenos mamiferos durante a estaçăo seca-fria, também já foi relatada para outras áreas da Regiăo Neotropical em estudos populacionais de pequenos mamíferos (Dietz, 1983; Fonseca \& Kierulff, 1989; Stallings, 1988; O'Connell, 1989).

Segundo Vickery \& Bider (1981), em temperaturas mais frias, pequenos roedores apresentam dificuldades na regulação da temperatura corporal e à medida que cresce a diferença entre a temperatura corporal e a do meio ambiente, aumenta a taxa metabólica para compensar a excessiva perda de calor. Conseqüentemente, para os roedores capturados, cujo tamanho corporal médio em adultos, variou de $93.8 \mathrm{~mm}$ em Oligoryzomys nigripes a $166.5 \mathrm{~mm}$ em Oxymycterus nasutus (Tabela 8), as chances de capturas tendem a aumentar nas noites mais frias.

Mamiferos maiores, como D. marsupialis (Figura 9), năo apresentaram flutuação sazonal, muito provavelmente por terem maior biometria e biomassa (Tabela 8), năo sofrendo influências de temperatura. Entretanto, fêmeas de $D$. marsupialis em condições reprodutivas foram observadas na estação chuvosaquente, estando em acordo com os relatos de Bergallo (1991) para a Estaçăo Ecológica da Juréia, SP. Nesta estação sazonal, ocorre um aumento na oferta de alimento favorecendo a atividade de reprodução. Porém, segundo JulienLaferrière \& Atramentowicz (1992), estes marsupiais possuem estratégias reprodutivas através de um mecanismo de "feed-back", conforme os recursos do habitat. Quando o ambiente encontra-se bastante alterado pela açăo antrópica, como foi verificado na área de estudo, a presença dominante de $D$. marsupialis entre os marsupiais é um bioindicador de áreas perturbadas, conforme foi observado por Paglia et al., 1995).

Quanto à sazonalidade das espécies de roedores, a maior riqueza de espécies foi observada durante a estação seca-fria. Todavia a ocorrência de Oxymycterus nasutus somente na estação seca-fria e $O$. hispidus principalmente na chuvosa-quente, com apenas um exemplar na seca, sugere uma possivel divisão de recursos no uso do habitat. O roedor mais abundante, Akodon cursor 
(Figura 10), năo apresentou flutuação sazonal nem diferenças significativas no nível populacional entre as estações, mas, naqueles meses em que houve maior riqueza de espécies, $A$. cursor esteve ausente, sugerindo que o habitat foi selecionado. Quando as respostas de muitas espécies e suas atividades no meio ambiente são comparadas, a ocorrência de divisão estrutural na estratégia de vida pode levar a uma menor competição e as diferentes espécies em uma comunidade, podem responder diferentemente para uma mesma flutuação ambiental (O'Connell, 1989).

A maior freqüência de carrapatos observada na estação seca-fria (Figura 19), pode ser constatada pelo aumento de larvas e ninfas de lxodes sp. coletadas durante esta estação sazonal (Figura 20). Porém, considerando os diferentes estágios biológicos do carrapato, bem como, suas preferèncias pelo hospedeiro, verifica-se que os exemplares imaturos ingurgitaram principalmente durante a estação seca-fria, havendo uma porcentagem maior de fêmeas ingurgitadas durante a estação chuvosa-quente (Tabela 5). Embora só uma fêmea de Amblyomma cajennense (Figura 8) tenha sido coletada durante a estação chuvosa-quente no início do processo de ingurgitamento, seus estágios imaturos ocorrem principalmente durante a estação seca-fria, os chamados periodos de invernada (Flechtmann, 1977), atacando vorazmente seus hospedeiros.

As fêmeas de 1. loricatus alimentaram-se preferencialmente durante a estação chuvosa-quente, enquanto que as fêmeas de l. dide/phidis ingurgitaram igualmente em ambas as estaçס̄es. Poucos machos de ambas espécies foram observados principalmente durante a estaçăo chuvosa-quente, fixos à pele do hospedeiro.

Esta sazonalidade pode ainda ser evidenciada mensalmente (Figura 21),. quando se analisou a distribuição dos diferentes estágios biológicos das espécies de carrapatos coletadas nos mamiferos em relação à temperatura e pluviometria médias, apesar de faltarem dados para o segundo semestre de 1997, os quais poderiam refletir melhor esta distribuição mês a mês. As larvas e 
ninfas de /xodes sp. (Figura 3a e b) atingiram o maior pico em Agosto/1995, dois meses após a menor média de temperatura e durante a menor média pluviométrica. Estes carrapatos imaturos, provavelmente sejam resultantes de fêmeas maduras que depositaram ovos nos primeiros meses do ano. Individuos adultos da espécie I. didelphidis foram coletados regularmente de Janeiro a Abril/1995 e de Janeiro a Junho/1996, desaparecendo entre Maio e Dezembro/1995; entretanto, apesar da distribuição irregular, adultos de 1 . loricatus apareceram principalmente naqueles meses quando 1. didelphidis esteve ausente. Estas duas espécies só foram coletadas juntas em Janeiro/1995 e em Abril/1996. O pico máximo de I. loricatus e I. didelphidis foi registrado em Janeiro/1995 e em Abril/1995, respectivamente. A ausência de I. didelphidis nos meses em que I. loricatus foi predominante, sugere uma possibilidade de estratégia para diminuir a competição pelo hospedeiro, entre as duas espécies na fase adulta.

Quando se analisa a prevalència mensal de carrapatos por grupo de mamiferos (Tabela 6), o pico máximo de infestaçăo de carrapatos adultos em marsupiais, ocorreu em Janeiro/1995 (Ponto 1 da Figura 2) e a maior infestação de carrapatos imaturos em roedores, foi em Agosto/1995 (Ponto 8b da Figura 2). Estes valores demonstram o grau de infestação de carrapatos adultos (estação chuvosa-quente) e imaturos (estação seca-fria) nos dois respectivos pontos de coletas e, quando comparados com a Tabela 3, verifica-se em ambos os pontos, os maiores índices de densidade relativa de carrapatos, sugerindo alta infestação nestes locais.

Embora o $\chi 2$ năo tenha sido significativo, os mamiferos machos foram mais parasitados que as fêmeas, apresentando os maiores índices de infestação em hospedeiros adultos (Tabela 7), excetuando Bolomys lasiurus que apresentou infestação somente em jovens. Oligoryzomys nigripes teve um índice de infestação maior do que as espécies Akodon cursor e B. lasiurus, cujos indices de infestação foram equivalentes. Em média, os índices totais, foram de 0.9 carrapatos por hospedeiro para $D$. marsupialis e 0.5 para os roedores, 
representando respectivamente, $62.5 \%$ e $37.5 \%$ do total de carrapatos coletados.

Considerando o ciclo biológico, de dois anos ou mais, para espécies americanas de Ixodes que pertencem ao complexo I. ricinus (Yuval \& Spielman, 1990), é possivel que as espécies I. didelphidis e I. loricatus coletadas no presente estudo, possam completar o seu ciclo biológico em um ano, uma vez que na América do Sul, os invernos na regiåo Sudeste săo bem mais amenos e as condições climáticas em área de Floresta Atlanntica são mais favoráveis. No Sul, entretanto, em áreas de Florestas com Araucária angustifolia, a espécie I. auritulus, que não pertence ao complexo I. ricinus (Clifford et al., 1973), foi coletada em aves durante 1990 a 1995, mostrando evidéncias de um ciclo biológico mais longo (manuscrito em preparação).

Dentre as espécies de Ixodes que ocorrem no Brasil, somente I. auritulus e I. affinis alcançam a América do Norte, segundo (Durden \& Keirans, 1996), embora Cooley \& Kohls (1945) tenham listado I. loricatus entre as espécies americanas. A espécie I. auritulus distribui-se até o Alaska, enquanto I. affinis distribui-se até o sul dos Estados Unidos sendo a Flórida seu limite máximo de distribuição (Barros-Battesti \& Knysak, 1998).

\section{VI.2. Sazonalidade da infeç̧ão em mamíferos e carrapatos}

De Janeiro/1995 a Maio/1995, houve uma certa regularidade de marsupiais infectados com espiroquetas, havendo escassês de individuos infectados nos meses seguintes (Tabela 9). Em quatro destes marsupiais foram coletados carrapatos também positivos. As maiores porcentagens de carrapatos infectados foram verificadas nos meses de Janeiro e Março de 1995 e em Abril de 1996, sendo que os machos de I. didelphidis foram mais infectados que as fêmeas, ocorrendo o contrário em relação a I. loricatus (Tabela 10, Figura 22). Segundo Oliver Jr. (1996) a transmissão transovariana de B. burgdorferi ocorre, mas é menos comum nos lxodes americanos. Considerando a possibilidade de transmissão transovariana das espiroquetas nos carrapatos coletados no 
presente estudo, o fato de haver mais fêmeas infectadas que machos de 1 . loricatus na estação chuvosa-quente, sugere que estas fêmeas podem originar um maior número de larvas infectadas durante a estaçăo seca-fria.

Dos sete roedores positivos para espiroquetas (Tabela 11), quatro foram capturados durante a estação chuvosa-quente (Março/1995, Janeiro e Fevereiro/1996) e très foram capturados na seca-fria (Abril/1995). Dentre seis exemplares de Oxymycterus hispidus coletados principalmente durante a estação chuvosa-quente, três indivíduos (50\%), sendo dois machos capturados respectivamente, em Março/1995 (ponto 3) e em Janeiro/1996 (ponto 13a), e uma fêmea capturada em Fevereiro/1996 (ponto 14 a), os três exemplares estavam positivos para espiroqueta; entretanto, esta espécie nunca apresentou infestação de carrapatos durante o período de estudo.

Somente três individuos de Akodon cursor, um macho e duas fêmeas, tiveram culturas positivas entre os 30 exemplares coletados, representando $10 \%$ de individuos infectados, sendo que dois indivíduos foram capturados na estação seca-fria (Abril/1995, ponto 4a) e um na chuvosa-quente, coincidindo no mesmo ponto de coleta do exemplar macho de Oxymycterus hispidus infectado (Janeiro/1996, ponto 13a). Em Bolomys lasiurus, as espiroquetas cresceram apenas em cultura de baço de um exemplar capturado em Abril/1995, no mesmo ponto de coleta dos indivíduos $A$. cursor positivos.

Todos os exemplares de carrapatos coletados em $A$. cursor, estavam negativos para espiroqueta (Tabela 12). Todavia, as culturas de sangue e baço do individuo DR2 (Tabela 11) procedente do ponto $4 a$, apresentaram crescimento de espiroquetas. Das três larvas e sete ninfas coletadas em dois exemplares de Oligoryzomys nigripes, duas larvas e cinco ninfas estavam infectadas, enquanto que as très larvas de dois exemplares de Bolomys lasiurus estavam positivas (Figura 24).

Apesar de aumentar significativamente as capturas de mamíferos e carrapatos durante a estaçăo seca-fria, o número de marsupiais e carrapatos infectados com espiroquetas, foi maior na estaçăo chuvosa-quente. Embora o 
número de roedores e carrapatos coletados tenha sido muito superior na estação seca-fria, o número de individuos infectados foi equivalente em ambas as estações, sendo que os carrapatos coletados nos roedores, somente apresentaram espiroquetas durante a estação seca-fria (Figura 25).

Na tentativa de se obter maiores informações através das recapturas de D. marsupialis, quanto a possibilidade de contato com o agente etiológico e as perspectivas de evidências de transmissão sazonal, ao final de cada fase de campo, os marsupiais foram devolvidos ao ambiente. $O$ indivíduo D3 (capturado em Fevereiro, Março, Maio/1995, respectivamente nos pontos 2, 3 e 5a), o indivíduo D6 (capturado em Fevereiro, Março e Novembro/1995, respectivamente nos pontos 2,3 e 11c) e o D7 (capturado em Fevereiro, Março/1995, respectivamente nos pontos 2 e 3), apresentaram espiroquetas em culturas de sangue somente na primeira captura. Foram recapturados ainda, quatro indivíduos que não estavam infectados com espiroquetas e nem tampouco infestados com carrapatos. Nos animais infectados quando da primeira captura, é possivel que as espiroquetas tenham migrado para as vísceras, após o período de espiroquetemia. Entretanto, em gambás, năo se conhece a persisténcia da espiroqueta na corrente circulatória.

Em cobaios infectados com $B$. burgdorferi, a espiroquetemia pode persistir por até 7 meses, mas a fase mais infectiva para carrapatos 1 . scapularis, foi verificada após 30 dias, conforme demonstrado por Piesman (1988), através de teste xenodiagnóstico.

Modelos experimentais com aves aquáticas da espécie Anas platyrhynchos platyrhynchos, responde à espiroquetemia de forma semelhante quando inoculadas com B.burgdorferi. Burgess (1989) em seu experimento inoculou $B$. burgdorferi em 4 patos por via oral, 4 patos por via intraperitonial e 2 aves serviram como controle. Naquelas aves infectadas oralmente, foi encontrado borrelias tanto no material cloacal como no figado 22 dias pósinfecçăo. Nos patos inoculados intraperitonialmente, as espiroquetas foram detectadas no sangue 29 dias pós-infecção. 
Em carrapatos Amblyomma americanum coletados no Missouri, New Jersey, New York, Carolina do Norte e Texas, foi identificada uma espécie de borrelia não cultivável, $B$. lonestari sp. n., e tem sido postulada como provável agente etiológico de borreliose de Lyme nestas áreas por Barbour et al. (1996).

Para o Brasil, há registro de apenas uma espécie de borrelia denominada de Borrelia brasiliensis por Davis (1952), tendo sido encontrada no sangue de roedor de laboratório, que serviu de hospedeiro para um carrapato argasídeo da espécie Ornithodoros brasiliensis procedente do Rio Grande do Sul. O sangue obtido da cauda do animal infectado, foi injetado em outros ratos numa série consecutiva até a sétima passagem da espiroqueta no sangue periférico. Entretanto, o autor verificou que a cepa desapareceu após a sétima passagem no sangue desde a primeira observação, não sendo mais recuperado do hospedeiro, nem tampouco do carrapato. Porém quando o sangue infectado foi injetado em 2 cobaios, as espiroquetas persistiram na corrente circulatória dos cobaios por aproximadamente sete dias, causando febre nos animais.

Pinto \& Primo (1931) relataram que pessoas picadas por O. brasiliensis, queixaram-se de dor de cabeça, dispineia e aumento da temperatura corporal, sendo especulado pelos autores, uma possivel relação do carrapato com a doença, embora a febre reincidente não tenha sido registrada para o Estado do Rio Grande do Sul. Entretanto, a B. brasiliensis nunca mais foi assinalada, sendo desconhecido o seu papel real como patógeno em humanos.

Tendo em vista a possibilidade da participação de argasídeos como vetores de B. burgdorferi, conforme foi relatado por Butler \& Denmark (1990), nós inoculados alguns camundongos isogénicos intraperitonialmente com $B$. burgdorferi (cepa americana), para observarmos o periodo entre o inóculo e o aparecimento das espiroquetas na corrente circulatória, tendo por finalidade, alimentar carrapatos Ornithodoros talaje (Argasidae) nestes animais infectados e verificar a suscetibilidade destes carrapatos à infecçăo, bem como, a capacidade de manutençăo das borrelias transestadialmente. Foi observado que a espiroquetemia nos roedores, ocorreu aproximadamente 30 dias após a 
inoculaçăo e que as larvas e ninfas destes carrapatos, adquiriram a borrelia, mas perderam-na após a terceira muda (dados não publicados).

Quanto à morfologia das espiroquetas encontradas nos animais de Itapevi, verificou-se que nos "in print" de rim e baço (Figura 31a e b) as espiroquetas são menores em comprimento do que aquelas observadas em "in print" de bexiga e fígado (Figura 33a e b) e em esfregaço sanguíneo (Figura 32). É possivel que o corante Giemsa possa ter contribuido para reduzir o comprimento celular; entretanto, as substâncias químicas produzidas pelo próprio órgão poderiam igualmente estar contribuindo para estas alteraçőes. Segundo Barbour \& Hayes (1986), em culturas de borrelias ocorrem variações tanto em comprimento como em amplitude das espiras, quando os nutrientes não estão adequados ou ainda, em função de adaptação quando são utilizados diferentes animais para experimentaçåo.

\section{VI.3. Vigilância epidemiológica em áreas endêmicas}

A situação da doença de Lyme no Canadá e Estados Unidos, tem levado a uma constante conscientização sobre a emergência da doença em populações recentes sob circunstáncias de risco, em áreas suburbanas onde ocorre exposição ocupacional. Um surto explosivo foi descrito em uma comunidade que vive em áreas adjacentes a uma região de preservação natural em Massachusetts (Lastavica et al., 1989).

Um Sistema de Vigilância Nacional para a doença de Lyme foi implantado nos Estados Unidos desde 1982. Porém, este sistema tornou-se completamente estabelecido somente em 1991. Foi adotado uma definição uniforme de caso, cujas leis foram implementadas em 46 estados americanos. Neste sistema, o CDC recebe semanalmente os registros de casos dos Departamentos de Saúde dos Estados e os encaminha para publicaçăo no MMWR. Uma análise geral de todos os dados é interpretada anualmente. Adicionalmente têm sido realizado esforços no sentido de criar um mapa de distribuiçăo por localidade, com a 
finalidade de se identificar a transmissão enzoótica local, bem como as variações introduzidas nas áreas onde ocorre transmissão.

O número de casos vem aumentando regularmente desde 1982, possivelmente refletindo um aumento real de incidencia. O suave declínio que ocorreu de 1994 para 1995, pode estar relacionado a fatores ecológicos. Como resultante das variaçőes do meio ambiente, estes fatores ecológicos, exercem influência nas populaçóes de lxodes scapularis que é o vetor principal no Nordeste e Centro Norte dos Estados Unidos.

Foram registrados 11.603 casos de doença de Lyme pelo Center Diseases Control (CDC, 1995) em 43 estados americanos em 1995 e o Distrito de Columbia apresentou uma incidéncia na população de 4.4/100.000 habitantes. Esta é a segunda taxa mais alta desde 1982, mas com um declinio de $11 \%$ nos 13.043 casos registrados em 1994. Porém em 1996, o número de casos aumentou para 16.461 , representando um acréscimo de $41 \%$, com uma incidéncia de 6.2/100.000 habitantes (CDC, 1997). Durante as últimas décadas a doença de Lyme espalhou-se em novas áreas causando surtos no Nordeste, Norte Central e nas regiōes do atlântico central dos Estados Unidos. As taxas de 4.4/100.000 habitantes também foram registradas em oito estados nas áreas endêmicas onde o número de doentes foi de 10.640 (92\%) do total de casos.

A proporçăo de doentes entre 0 e 17 anos foi de 2760 (24\%) e de adultos entre 35 a 49 anos foi de 2797 (24\%). Em 11.504 casos, 5811 (51\%) eram do sexo masculino.

Foi observado uma redução no número de casos de borreliose de Lyme na Georgia e no Missouri. A explicação para isto seria porque houve uma maior conscientização dos profissionais da saúde que atuam em áreas não endẻmicas ou porque as lesões pele causadas por carrapatos têm sido associadas a outras etiologias.

Nenhum caso do Missouri ou do Sul dos Estados Unidos, foi até o presente momento, confirmado pelo isolamento de Borrelia burgdorferi. Um tipo semelhante de doença de Lyme, caracterizada por uma lesão na pele similar ao 
eritema migratório porém com sorologia negativa para $B$. burgdorferi, foi registrada por Campbell et al. (1995), entre os pacientes da Georgia e do Missouri.

Na Segunda Conferéncia Nacional de Diagnósticos Sorológicos de Doença de Lyme (CDC, 1995), foi recomendado o uso de um teste duplo para sorodiagnóstico. O primeiro seria o teste de sensibilidade à enzima imunoabsorvente (ELISA) e imunofluorescência indireta (IFA). Para aqueles resultados positivos ou confusos, foi recomendado o teste Western-blotting, de maior especificidade. Por causa da sensibilidade e especificidade do ELISA e Western-blotting, os resultados podem variar. Deve se, portanto, considerar o tempo de exposição e a história clínica do paciente para a interpretação sorológica.

Os estudos para produção de vacina contra a borreliose de Lyme encontram-se em estágios avançados, embora com inúmeros problemas a serem resolvidos (Coyle, 1993). A inoculação de espiroquetas vivas carreiam riscos de infeç̧ão que podem ser incontroláveis, uma vez que $B$. burgdorferi é conhecida como causadora de infecção crônica persistente. O uso de espiroquetas inativadas requer um processo que assegure a morte de todos os organismos viáveis sem destruição estrutural de sua imunogenicidade. Além disso, esta técnica também requer um cultivo "in vitro" em grandes quantidades, fato este que acarreta a adoção de uma boa infraestrutura de recursos humanos e tecnológicos, o que não é tão simples.

Grandes esforços têm levado ao desenvolvimento de proteinas ou peptideos sintéticos para a produçăo de imunógenos. A identificação de genes que codificam proteinas imunogênicas, pode ser usada para clonar DNA. Este pode ser inserido, por exemplo, em Escherichia coli para produzir grandes quantidades de proteina purificada ou epitopos de proteina (peptideos), proporcionando a obtenção de antígenos puros. Tais antígenos não têm sido bem identificados para a doença de Lyme em humanos, mas o mais conhecido é a lipoproteina OspA, porém baseada somente em modelos animais. Anticorpos 
para OspA surgem cedo em infecçőes animais, entretanto em humanos, a resposta chega tarde e é bastante variável (Coleman \& Benach, 1987). Além disso, ainda não está claro se uma vacina simples poderá ser apta para oferecer imunidade a diferentes cepas de $B$. burgdorferi.

Enquanto isso, medidas preventivas são ainda as mais utilizadas, como: uso de repelentes para carrapatos, inspeção rigorosa para a remoçăo precoce dos vetores fixados na pele e uso de carrapaticidas em áreas frequentadas por veados. Estes métodos continuam a ser importantes para a reduçăo de riscos nas áreas endêmicas, além de serem preventivos para outras doenças veiculadas por ixodideos.

\section{VI.4. Avaliaçăo da situaçăo de riscos de infeç̧ăo em humanos}

O encontro de Amblyomma cajennense em pequenos mamíferos silvestres não foi incomum na área de estudo, apesar de parasitar animais domésticos preferencialmente. Esta espécie e $A$. aureolatum, foram coletadas em marsupiais, entre setembro/1993 e agosto/1994, durante a realização do plano piloto (Barros-Battesti et al., 1995; Yoshinari et al., 1995). No presente estudo, A. cajennense foi coletada novamente em marsupial, apresentando cultura positiva para espiroqueta; todavia $A$. aureolatum não foi observada nos hospedeiros estudados, mas ocasionalmente este carrapato foi coletado em cão doméstico do condomínio, tendo apresentado crescimento de espiroquetas na cultura. Ambas espécies picam o homem vorazmente, principalmente nas fases imaturas.

Um outro fato interessante foi a captura de Rattus norvegicus, em Fevereiro/1996 no ponto 14b, dentro da área florestada (Figura 34). Apesar de năo estar infestado com carrapatos e nem infectado com espiroquetas, este roedor urbano é incomum em área de floresta. Nos pontos 14b e 14a, foram capturados respectivamente, um exemplar D. marsupialis (D38) parasitado por $I$. didelphidis positivo para espiroquetas (Tabela 9) e um roedor Oxymycterus hispidus (DR57) infectado no fígado (Tabela 11). Na Europa, roedores urbanos 
infectados experimentalmente com Borrelia afzelii, demonstraram ser reservatórios competentes para a borreliose (Matuschka et al., 1997); entretanto, no Brasil, estes roedores são mais comumente hospedeiros para pulgas vetoras de pestes e ácaros Mesostigmata, sendo raramente parasitados por carrapatos.

Apesar da inexistência de provas sobre o envolvimento de outros artrópodes como vetores para a doença de Lyme, Pokorny (1989) observou a presença de B.burgdorferi em 13 espécies de Acari, 15 espécie de moscas e 2 espécies de pulgas, todos encontrados naturalmente infectados. A incidência de anticorpos contra B.burgdorferi em animais procedentes da mesma localidade, revelou-se positiva em 8 espécies de aves passeriformes e em 22 espécies de mamiferos silvestres, incluindo marsupiais.

Casos de doença de Lyme no Estado do Mato Grosso do Sul, levou a uma investigação de pequenos mamíferos e carrapatos em ambiente de mata no município de Campo Grande. Foram coletados somente carrapatos do gênero Amblyomma não sendo encontrado Ixodes nos animais investigados. Houve crescimento de espiroquetas em cultura de figado de um roedor e em cultura de carrapatos imaturos de Amblyomma (Isaias P. Costa, tese de doutorado em andamento - Faculdade de Medicina da USP).

Por outro lado, a possibilidade de lxodes picar humanos no Brasil, deve ser considerada uma vez que, muitos hospedeiros antes restritos ao ambiente de mata, hoje vivem em fragmentos isolados de vegetação junto às áreas rurais e urbanas, convivendo no ambiente peri-domiciliar com animais domésticos, podendo acarretar intercâmbio e adaptação de ectoparasitos entre os ambientes, bem como a veiculação de patógenos.

De 1990 a 1995, dos 500 casos suspeitos no Brasil, 25 portadores da doença foram detectados, sendo 18 femininos e sete masculinos, na faixa etária entre 4 e 48 anos. A casuistica revelou quinze casos na fase aguda, sete no estágio secundário (latente ou recorrente) e três evoluindo da fase aguda para latente (Yoshinari et al., 1995). 
Os sintomas clínicos nem sempre evidentes e o difícil diagnóstico, contribuem para a evolução a um quadro crónico da doença (Yoshinari et al., 1997). Além da reatividade cruzada das borrélias com outras espiroquetoses, tais como sifilis e leptospirose, observa-se também, reação cruzada com a Febre Reumática de carater autoimune com Streptococcus betahemolítico do grupo A (Giancarla Gauditano, tese de doutorado aguardando defesa Faculdade de Medicina da USP).

O aspecto clínico da doença de Lyme é o Eritema Crônico Migratório (ECM), lesão cutânea expansiva de borda eritematosa e fundo claro, que surge no ponto de inoculação do agente etiológico (Yoshinari et al., 1993a). Esta lesão primária permanece em geral por 4 a 20 dias, podendo extender-se por até alguns meses. Na fase septicêmica, podem aparecer outras lesōes chamadas de eritema anular secundário menos expansivas que o ECM, podendo atingir troncos e membros. Geralmente estão acompanhadas de manifestações clínicas que lembram um quadro gripal.

$\mathrm{Na}$ fase aguda, podem aparecer poucas espiroquetas circulantes no sangue ou presente nas lesões. Porém, as chances de isolamento do microrganismo no sangue são mínimas. $\mathrm{Na}$ fase secundária, semanas ou meses após o contágio inicial, são observadas oligoartrites de grandes articulações, meningorradiculite e outras lesões secundárias (Steere, 1989).

Complicações podem surgir tardiamente como acrodermatite crônica atrófica, lesão cutânea tardia semelhante a esclerodermia em placa com periostite do osso adjacente, artrite crônica semelhante à doença reumatóide, fadiga crónica, distúrbios de comportamento, entre outras. Pode ainda ocorrer miocardites, cardiomegalia e disfunção ventricular, havendo o encontro de borrelias no miocárdio, em raros casos fatais. Na América do Norte, estima-se que $4 \%$ a $10 \%$ dos pacientes apresentam comprometimento cardiaco (Cox \& Kraden, 1991).

Sintomas sugestivos de irritação meningeal, caracterizados por cefaléia e rigidez de nuca, podem surgir no início da doença quando o ECM está presente, 
assemelhando-se à meningite. Este quadro clínico envolvendo complicaçōes neurológicas, com ou sem ECM, tem sido mais freqüente em pacientes com doença de Lyme no Mato Grosso do Sul, cujas manifestações neurológicas podem ser observadas tanto na fase de disseminaçăo precoce como na fase tardia da doença (Isaias P. Costa, tese de doutorado em andamento). Na Regiāo Sudeste, também tem sido constatada a ocorrência de paralisia facial (Sulene Pirana, tese de doutorado em andamento - Faculdade de Medicina da USP).

$O$ isolamento de um agente etiológico autóctone, possibilitaria a realização das provas imunológicas com antígenos específicos que contribuiriam para o correto diagnóstico laboratorial dos casos clínicos. Mas, apesar de todos os esforços para isolar as espiroquetas e tentar identificá-las através de microscopia eletrônica, não houve sucesso devido a grande contaminação das culturas. Foram realizadas várias tentativas no sentido de reduzir os contaminantes, através de antibióticos e filtragem; entretanto, as espiroquetas sofrem a ação dos antibióticos e ređuzem consideravelmente nas culturas filtradas. Outra técnica foi o cultivo em meio sólido para facilitar o isolamento na presença de contaminantes, mas as espiroquetas brasileiras não se desenvolveram, ocorrendo exatamente o contrário com $B$. burgdorferi que apresentou bom crescimento neste meio de cultura (Alexandre D. Zeitune, comunicaçăo pessoal).

Foram ainda, realizados vários testes de PCR (reação de polimerase em cadeia), mas o resultado tem sido sempre negativo (Paulo José L. Barros, tese de doutorado em andamento - Faculdade de Medicina da USP), embora estes testes ainda estejam em fase de padronização.

É possivel que estes microrganismos encontrados nos animais e carrapatos que foram investigados no presente estudo, năo sejam do gênero Borrelia; entretanto, também não săo Leptospira, porque as amostras de sangue destes mamíferos positivos para espiroquetas visualizadas em microscópio de 
campo escuro, foram submetidas à microaglutinação para 24 sorotipos de Leptospiras por (Mori et al., 1996), cujos resultados foram negativos.

Nos testes de sorologia, pelo método ELISA indireto e ELISA de captura de antigenos, realizados por Bonoldi et al. (1996) com as amostras de soro dos marsupiais capturados em Itapevi, constatou-se positividade respectivamente em, 91\% (31/34) e em 21.4\% (6/28). Alexandre D. Zeitune (comunicação pessoal) testou as amostras de soros dos roedores capturados através da técnica de hemaglutinaçăo utilizando $B$. burgdorferi, resultando $20 \%$ positivos.

Embora estes microrganismos ainda năo tenham sido isolados e identificados, há fortes evidências de que pertençam ao gênero Borrelia uma vez que foram encontrados nos mamiferos e carrapatos; apareceram em culturas inoculadas com macerados de larvas de carrapatos colhidos nos roedores, porém estes não estavam infectados, levando a crer que a espiroqueta pode estar sendo transmitida transovarianamente, apesar da possibilidade dos carrapatos terem se infectado por via não sistêmica considerando a alimentação simultânea, como foi relatado por Randolph et al. (1996) para outros carrapatos; crescem em meio de cultura BSK próprio para borrelias; estão presentes praticamente em toda a área estudada (Figura 34) incluindo o local onde surgiram casos da doença.

Conseqüentemente, na área do condomínio residencial Transurb, é altamente provável que os marsupiais e roedores silvestres, bem como, carrapatos imaturos do gênero Ixodes e as espécies Ixodes didelphidis, I. loricatus e Amblyomma cajennense, tomem parte na estrutura zoonótica do agente etiológico, de modo a ser determinante de exposição do homem à doença. 


\section{CONCLUSŐES}

Há fortes evidéncias de que os microrganismos encontrados no presente estudo pertençam ao gênero Borrelia, uma vez, que:

- Foram encontrados em pequenos mamiferos e carrapatos dos gêneros Ixodes e Amblyomma.

- Crescem em meios de cultura BSK inoculados com sangue e órgãos de pequenos mamíferos silvestres e carrapatos.

- Considerando que cada vetor normalmente infecta um reservatório, e o reservatório pode amplificar horizontalmente a transmissão ao infectar vários vetores, a transmissão na área de estudo é mantida por roedores silvestres quando servem de hospedeiros para os estágios imaturos de Ixodes durante a estação seca-fria, estes, por sua vez, ao atingirem o estágio adulto, infectam os marsupiais principalmente durante a estaçăo chuvosa-quente.

- Os marsupiais infectados, hospedeiros principais de lxodes na fase adulta, quando săo picados por carrapatos do gènero Amblyomma, transportam o patógeno para o peridomicílio.

- As pessoas podem contrair a doença quando são picadas principalmente por carrapatos infectados do gènero Amblyomma, cuja espécie assinalada na área de estudo, é altamente eclética, podendo parasitar animais domésticos e humanos tanto quanto animais silvestres.

- A presença predominante de $D$. marsupialis entre os mamíferos capturados durante todo o periodo de estudo, tanto no peridomicilio como na mata, sugere este modelo de transmissão.

- Os focos naturais de espiroquetas estăo distribuidos praticamente, em toda a área peridomiciliar e mata do condominio residencial, confirmando os dados previamente registrados de endemismo para esta região. 


\section{ABSTRACT}

Several cases of human Lyme borreliosis were found in different Brazilian regions between 1990 to 1995. Four of them were from Cotia and Itapevi, municipalities, State of São Paulo. This study aims to contribute to the elucidation of the aspects of the transmission of borreliosis in a residential joint area, in Itapevi, State of São Paulo, where the firsts cases, with clinic and serology compatible with Lyme disease, were registered. The natural focus of spirochetes were studied during the period between January, 1995 to June, 1996. In a total 134 small wild mammals, and 88 ticks collected on them, were investigated. The adult ticks were identified as Ixodes didelphidis, I. Ioricatus and Amblyomma cajennense, and the immature stages as Ixodes sp. For both, hosts and ticks, the relative density index was correlated with meteorological data by Spearman and Pearson coefficients. For marsupials and ticks, these correlations were not significant. For rodents the correlations were significant and directly related to the lower temperature and rainfall indices $(p<0.05)$. The greater frequency of immature ticks occurred in the dry season, mainly on rodents; meanwhile, adult ticks, prevailed during the rainy season, occurring only on marsupials. Blood and organs of hosts and ticks were inoculated into BSK medium. Spirochetes like Borrelia were observed in $13 \%$ of marsupial blood culture of the Didelphis marsupialis species and in $36.4 \%$ of ticks collected on this host. Spirochetes were also observed in $9.7 \%$ of the blood and organs of the rodents Oxymycterus hispidus, Akodon cursor and Bolomys lasiurus and in $30.3 \%$ of the ticks collected on them. The infected mammals and adult ticks mainly occurred in the rainy season, and the infected immature ticks only in the dry season. There are strong evidences that these spirochetes belong to the genus Borrelia: they were found in small mammals and ticks; growed in inoculated medium with material from Ixodes larvae collected on non-infected 
rodents suggesting transovarial transmission; and grow in medium characteristic for Borrelia.

Key word: ticks spirochetes - mammals spirochetes - natural focus - Lyme borreliosis. 


\section{REFERÊNCIAS BIBLIOGRÁFICAS}

AFZELIUS, A. Erythema chronicum migrans. Acta Dermato-Venereol., 2: 120-25, 1921.

ANGELOV, L. Unusual features in the epidemiology of Lyme borreliosis. Eur. J. Epidemiol., 12: 9-11, 1996.

ARAGÃO, H.B. Ixodidas brasileiros e de alguns países limitrofes. Mem. Inst. Oswaldo Cruz, 31: 759-843, 1936.

ARAGÃO, H.B. \& FONSECA, F. Notas de Ixodologia III. Confirmação de Ixodes aragaoi Fonseca, 1935, de Ixodes amarali Fonseca, 1935 e lista de espécies do gênero Ixodes que ocorrem no Brasil (Acari:Ixodidae). Mem. Inst. Oswaldo Cruz, 50: 727-28, 1952.

ARAGĀO, H.B. \& FONSECA, F. Notas de Ixodologia, VIII. Lista e chave para os representantes da fauna ixodologica brasileira. Mem. Inst. Oswaldo Cruz, 59: 115-29, 1961.

ARZUA, M.; BARROS, D.M.; LINARDI, P.M. \& BOTELHO, J.M. Noteworthy records of Ixodes auritulus Neumann, 1904 (Acari, Ixodida) on birds from Paraná, Southern Brazil. Mem. Inst. Oswaldo Cruz, 89: 129, 1994.

ASBRINK, E. \& HOVMARK, A. Early and late cutaneous manifestations in Ixodes-borne borreliosis. Ann. N.Y. Acad. Sci., 539: 4-5, 1988.

AZULAY, R.D.; ABULAFIA, L.; SODRE, C.S.; AZULAY, R.A. \& AZULAY, M.M. Lyme disease in Rio de Janeiro, Brazil. Int. J. Dermatol., 30: 569-71, 1991.

BALASHOV, Yu. S. Bloodsucking ticks (lxodoidea) - vector of diseases of man and animals. Misc. Publ. Entomol. Soc. Am., 8: 161-376, 1972.

BANNWARTH, A. Zur klinik und pathogenese der "chronischen lymphocytären meningitis". Arch. Psychiatr. Nervenkr., 117: 161-85, 1944.

BARANTON, G.; POSTIC, D.; GIRONS, I.S., et al. Delineation of Borrelia burgdorferi sensu stricto, Borrelia garinii sp. nov., and group VS461 associated with Lyme Borreliosis. Int. J. Sys. Bacteriol., 42: 378-83, 1992. 
BARBOUR, A.G. Isolation and cultivation of Lyme disease spirochetes. Yale J. Biol. Med., 57: 521-5, 1984.

BARBOUR, A.G. \& HAYES, S.F. Biology of Borrelia species. Microbiol. Rev., 50: $381-400,1986$.

BARBOUR, A.G.; MAUPIN, G.O.; TELTOW, G.J.; CARTER, C.J. \& PIESMAN, J. Identification of an uncultivabel Borrelia species in the hard tick Amblyomma americanum: possible agent of Lyme disease-like illness. J. Infect. Dis., 173: 403-9, 1996.

BARROS, D.M. \& BAGGIO, D. Ectoparasites Ixodida Leach, 1817 on wild mammals in the State of Parana, Brazil. Mem. Inst. Oswaldo Cruz, 87: 291-6, 1992.

BARROS, P.J.L.; LEVY, L.M.; MONTEIRO, F.G.V. \& YOSHINARI, N.H. Doença de Lyme: acometimento cutaneo e tratamento das fases iniciais. Rev. Assoc. Med. Bras., 39: 170-2, 1993.

BARROS-BATTESTI, D.M. \& KNYSAK, I. Catalogue of the Brazilian Ixodes (Acari: Ixodidae) material in the mite collection of the Instituto Butantan, São Paulo, Brazil. Pap. Avulsos Zool., 40: 1998 (no prelo).

BARROS-BATTESTI, D.M.; ARZUA, M.; YOSHINARI, N.H. \& SCHUMAKER, T.T.S. Ectoparasitos (Acari e Siphonaptera) de marsupiais capturados em área de risco para a doença de Lyme, município de Itapevi, SP. Rev. Patol. Trop., 23: S215, 1995.

BEDFORD, G.A.H. South African ticks. Part I. Onderstepoort J. Vet. Sci. Anim. Ind., 2: 49-99, 1934.

BELOSEROV, V.N. Diapause and biological rhythms in ticks. In: Obenchain, F.D. \& Galun, R. Physiology of ticks. New York, Pergamon, 1982. p. 469-500.

BENESI, F.J.; BIRGEL, E.H.; PAGANELLI, C.H., et al. Lyme disease in cattle in Brazil. Vector Ecol. Newsl., 26: 5-6, 1995.

BERGALLO, H.G. Dinámica populacional, área de vida, parasitismo e mutualismo de pequenos mamíferos da estação ecológica da Juréia, SP, 
1991. [Dissertação de Mestrado - Instituto de Biologia da Universidade Estadual de Campinas].

BIER, O. Microbiologia e imunologia. São Paulo, Ed. Melhoramentos, 1985.

BONOLDI, V.L.N.; BARROS-BATTESTI, D.M.; FONSECA, A.H., et al. Participação de gambás (Didelphis marsupialis) no ciclo epidemiológico da doença de Lyme. Rev. Bras. Reumatol., 36: S276, 1996.

BURGDORFER, W.; BARBOUR, A.G.; HAYES, S.F.; BENACH, J.L.; GRUNWALDT, E. \& DAVIS J.P. Lyme disease, a tick-borne spirochetosis? Science, 216: 1317-9, 1982.

BURGESS, E.C. Experimental inoculation of mallard ducks (Anas platyrhynchos platyrhynchos) with Borrelia burgdorferi. J. Wildl. Dis., 25: 99-102, 1989.

BUTLER, J.F. \& DENMARK, H.A. Tick (Acari: Ixodidae) vectors of Lyme disease organisms (Borrelia burgdorfen) in Florida. Entomol. Circular., 326, 1990.

CAMPBELL, G.L.; PAUL, H.S.; SCHRIEFER, M.E.; CRAVEN, R.B.; ROBBINS, K.E. \& DENNIS, D.T. Epidemiologic and diagnostic studies of patients with suspected early Lyme disease, Missouri, 1990-1993. J. Infect. Dis., 172: 47080, 1995.

CASTRO, G.R. \& SERRA-FREIRE, N.M. Revisão da ixodofauna: I. Tamanduas (Tamandua sp.). Entomol. Vect., 3: 63-81, 1996.

CDC. Recomendations for test performance and interpretation from the Second National Conference on Serologic Diagnosis of Lyme disease. Morb. Mort. Wkly. Rep., 44: 590-1, 1995.

CDC. Lyme disease - United States, 1996. Morb. Mort. Wkly. Rep., 46: 531-5, 1997.

CLIFFORD, C.M.; SONENSHINE, D.E.; KEIRANS, J.E. \& KOHLS, G.M. Systematics of the subfamily Ixodinae (Acarina: Ixodidae). I. The subgenera of Ixodes. Ann. Entomol. Soc. Am., 66: 489-500, 1973.

COLEMAN, J.L. \& BENACH, J.L. Isolation of antigenic components from the Lyme disease spirochete: their role in early diagnosis. J. Infect. Dis., 155: 756, 1987. 
COOLEY, R.A. \& KOHLS, G.M. The genus Ixodes in North America. Nat. Inst. Health Bull., 184: 1-246, 1945.

COSTELLO, C.M.; STEERE, A.C.; PINKERTON, R.E. \& FEDER, J.R.H.M. A prospective study of tick bites in an endemic area for Lyme disease. J. Infect. Dis., 159:136-9, 1989.

COX, J. \& KRADEN, M. Cardiovascular manifestations of Lyme disease. Am. Heart J., 122: 1449, 1991.

COYLE, P.K. Vaccine development. In: Coyle, P.K. Lyme disease. St. Louis, Mosby Year Book, Inc., 1993. p. 172-5.

CRESPO, J.A. Ecología de una comunidad de roedores silvestres en el partido de Rojas, Provincia de Buenos Aires. Rev. Mus. Argent. Cienc. Nat. "Bernardino Rivadavia", 1: 79-134, 1966.

DAVIS, G.E. Observations on the biology of the argasid tick, Ornithodoros brasiliensis Aragão, 1923, with the recovery of a spirochete, Borrelia brasiliensis, n. sp. J. Parasitol., 38: 473-6, 1952.

DENNIS, D.T. Epidemiology. In: Coyle, P.K. Lyme disease. St. Louis, Mosby Year Book Inc., 1993. p. 27-37.

DIETZ, J.M. Notes on the natural history of some small mammals in central Brazil. J. Mammal., 64: 521-3, 1983.

DURDEN, L.A. \& KEIRANS, J.E. Nymphs of the genus Ixodes (Acari: Ixodidae) of the United States: taxonomy, identification key, distribution, hosts, and medicalveterinary importance. Lanham, Entomological Society of America, 1996.

EMONS, L.H. \& FEER, F. Neotropical rainforest mammals: a field guide. Chicago, USA, The university of Chicago Press, 1990.

FAIRCHILD, G.B.; KOHLS, G.M. \& TIPTON, V.J. The ticks of Panama (Acarina: Ixodoidea). In: Wenzel, R,L, \& Tipton, V.J. Ectoparasites of Panama. Chicago, Field Museum of Natural History, 1966. p. 167-219.

FELSENFELD, O. Borreliae, human relapsing fever, and parasite-vector-host relationships. Bacteriol. Rev., 29: 46-74, 1965. 
FEIR, D.; SANTANELLO, R.C.; LI, B.W., et al. Evidence supporting the presence of Borrelia burgdorferi in Missouri. Am. J. Trop. Med. Hyg., 51: 475-82, 1994.

FILIPPOVA, N.A. Taxonomy of ticks of the family Ixodidae (Acarina, Parasitiformes) in the USSR fauna and plans for studying it. Parazitol. Sb. Zool. Inst. Akad. Nauk SSSR., 32: 61-78. 1984.

FLECHTMANN, C.H.W. Ácaros de importáncia médico-veterinária. São Paulo, Livraria Nobel, 1977.

FONSECA, F. Ocorrència de sub-espécie Ixodes ricinus (L., 1758) no Estado de São Paulo (Acarina, Ixodidae). Mem. Inst. Butantan, 9: 131-5, 1935a.

FONSECA, F. Notas de Acarologia XI. Validade da espécie e ciclo evolutivo da Amblyomma striatum Koch, 1844 (Acari: Ixodidae). Mem. Inst. Butantan, 9: 19-27, 1935b

FONSECA, A.H.; SOARES, C.O.; ISHIKAWA, M.M.; MASSARD, C.L. \& YOSHINARI, N.H. Detection of Borrelia sp. in opossum (Marsupialia: Didelphidae) in Brazil. In: Congress of the World Veterinary Association, 25 Yokohama, Japan, 1995. Annals World Veterinary Association, Japan, 1995. p. 220.

FONSECA, G.A.B. \& KIERULFF, M.C.M. Biology and natural history of Brazilian Atlantic Forest small mammals. Bull. Fl. State Mus. Biol. Sci., 34: 99-152, 1989.

FOX, G.E.; STACHEBRANDT, E.; HESPELT, R.B., et al. The phylogeny of procaryotes. Science, 209: 457-63, 1980.

FRASER, C.M.; CASJENS, S.; HUANG, W.M., et al. Genomic sequence of Lyme disease spirochaete, Borrelia burgdorferi. Nature, 390: 580-6, 1997.

GERN, L. \& RAIS, O. Efficient transmission of Borrelia burgdorferi between cofeeding Ixodes ricinus ticks (Acari: Ixodidae). J. Med. Entomol., 33: 189-92, 1996.

GLASS, G.V. \& STANLEY, J.C. Metodos estatisticos aplicados a las ciencias sociales. Spanã, Editorial Prentice/Hall International, 1980. 
GUIMARÃES, L.R. Sobre alguns ectoparasitos de aves e mamíferos do litoral paranaense. Arq. Mus. Parana., 4: 179-90, 1945.

GUITTON, N.; ARAÚJO FILHO, N.A. \& SHERLOCK, I.A. Ectoparasitos de roedores e marsupiais no ambiente silvestre de llha Grande, Estado do Rio de Janeiro, Brasil. Mem. Inst. Oswaldo Cruz, 81: 233-4, 1986.

HERSHKOVITZ, P. The South American gracile mouse opossums, genus Gracilinanus Gardner and Creighton, 1989 (Marmosidae, Marsupialia): a taxonomic review with notes on general morphology and relationships. Fieldiana, 70: 1-56, 1992

HERXHEIMER, K. \& HARTMANN, K.U. Acrodermatitis chronica atrophicans. Arch. Dermatol. Syphilol., 61: 57-76, 1902.

HONACKI, J.H.; KINMAN, K.E. \& KOEPPL, J.W. Mammal species of the world. Lawrence, Allen Press, 1982.

HOOGSTRAAL, H. Biology of ticks. In: Wilde, JKH. Tick-borne diseases and their vectors. Proc. Int. Conf., Edinburgh, Univ. Edingurgh, 1978. p. 3-14.

HOOGSTRAAL, H. Argasid and Nuttaliellid ticks as parasites and vectors. Adv. Parasitol., 24:135-238, 1985.

HOOGSTRAAL, H. \& AESCHLIMANN, A. Tick-host specificity. Bull. Soc. Entomol., 55: 5-32, 1982.

HOVIND-HOUGEN, K. Treponema and Borrelia morphology. In: Johnson, R.C. The biology of parasitic spirochetes. New York, Academic Press, Inc., 1976. p. 7-17.

HOVIND-HOUGEN, K. Ultrastructure of spirochetes isolated from Ixodes ricinus and Ixodes dammini. Yale J. Biol. Med., 57: 543-8, 1984.

ISHIGURO, F.; IIDA, H.; HATANO, M.; YANO, Y. \& TAKADA, N. Tick fauna and the prevalence of Lyme Borrelia in Fukui Prefecture. J. Acarol. Soc. Jpn., 1: 37-44, 1992.

JONES, E.K.; CLIFFORD, C.M.; KEIRANS, J.E. \& KOHLS, G.M. The ticks of Venezuela (Acarina: Ixodoidea) with a key to the species of Amblyomma in 
the western hemisfere. Brigham Young Univ. Sci. Bull. Biol. Ser., 17: 1-40, 1972.

JOPPERT, A.M. Estudo soroepidemiológico da infecçăo por Borrelia burgdorferi em cáes da regiăo de Cotia, SP, 1995. [Dissertaçăo de Mestrado - Faculdade de Medicina Veterinária e Zootecnia da Universidade de São Paulo].

JULIEN-LAFERRIERE, D. \& ATRAMENTOWICZ, M. Feeding and reproduction of three didelphid marsupials in two neotropical forests (French Guiana). Biotropica, 22: 404-15, 1992.

KEIRANS, J.E. Systematics of the Ixodida (Argasidae, Ixodidae, Nuttaliellidae): an overview and some problems. In: Fivaz, B.; Petney, T. \& Horak, I. Tick vector biology medical and veterinary aspects. Berlin, Springer, 1992. p.1-21.

KEIRANS, J.E.; CLIFFORD, C.M.; HOOGSTRAAL, H. \& EASTON, E.R. Discovery of Nuttalliella namaqua Bedford (Acarina: Ixodoidea: Nuttalliellidae) in Tanzania and redescription of the female based on scanning electron microscopy. Ann. Entomol. Soc. Am., 69: 926-32, 1976.

KELLY, R. Cultivation of Borrelia hermsii. Science, 173: 443-4, 1971.

KLOMPEN, J.S.H.; BLACK, W.C. IV; KEIRANS, J.E. \& OLIVER Jr., J.H. Evolution of ticks. Annu. Rev. Entomol, 41: 141-61, 1996.

KRAVETZ, F.O. Estudio del régimen alimentário, períodos de actividad y otros rasgos ecológicos en una población de "Raton hocicudo" (Oxymycterus rufus platensis, Thomas) de Punta Lara. Acta Zool. Lilloana, 29: 201-13, 1972.

LANE, R.S.; PIESMAN, J. \& BURGDORFER, W. Lyme borreliosis: relation of its causative agent to its vector and hosts in North America and Europe. Annu. Rev. Entomol., 36: 586-609, 1991.

LANGUTH, A. Las espécies uruguayas del género Oryzomys (Rodentia Cricetidae). Comm. Zool. Mus. Hist. Nat. Montevideo, 99: 1-23, 1963.

LASTAVICA, C.C.; WILSON, M.L.; BERARDI, V.P.; SPIELMAN, A. \& DEBLINGER, R.D. Rapid emergence of a focal epidemic of Lyme disease in coastal Massachusetts. N. Engl. J. Med., 320: 133-7, 1989. 
LINARDI, P.M.; BOTELHO, J.R.; NEVES, D.P. \& CUNHA, H.C. Sobre alguns ectoparasitos de roedores silvestres de Belo Horizonte, MG. Rev. Bras. Biol., 44: 215-9, 1984.

LOPES, C.M.L.; LINARDI, P.M. \& BOTELHO, J.R. Ectoparasitos de roedores do municipio de Tiradentes, MG. I. Ectoparasitofauna. Mem. Inst. Oswaldo Cruz, 84: 333-4, 1989.

MAGNARELLI, L.A.; ANDERSON, J.F.; APPERSON, C.S.; FISH, D.; JOHSON, R.C. \& CHAPPELL, W.A. Spirochetes in ticks and antibodies to Borrelia burgdorferi in white tailed deer from Connecticut, New York State, and North Carolina. J. Wildl. Dis., 22:178-88, 1986.

MARCONI, R.T.; LIVERIS, D. \& SCHWARTZ, I. Identification of novel insertion elements, restriction fragment length polymorphism patterns, and discontinuous 23S rRNA in Lyme disease spirochetes: Phylogenetic analyses of rRNA genes and their intergenic spacers in Borrelia japonica sp. nov. and genomic groups 21038 (Borrelia andersonii sp. nov.) isolates. J. Clin. Microbiol., 33: 2427-34, 1995.

MARKOWITZ, L. E.; STEERE, A.C.; BENACH, J.L.; SLADE, J.D. \& BROOME, C.V. Lyme disease during pregnancy. JAMA, 255: 3394-7, 1986.

MATUSCHKA, F.R. \& SPIELMAN, A. Loss of Lyme Disease Spirochetes from Ixodes ricinus ticks feeding on European blackbirds. Exp. Parasitol., 74: 1518, 1992.

MATUSCHKA, F.R.; ENDEPOLS, S.; RICHTER, D. \& SPIELMAN, A. Competence of urban rats as reservoir hosts for Lyme disease spirochetes. $J$. Med. Entomol., 34: 489-93, 1997.

MENDEZ-AROCHA, M. \& ORTIZ, I. Revision de las garrapatas venezuelanas del genero Ixodes Latr., y estudio de un nuevo Amblyomma. Mem. Soc. Cienc. Nat. La Salle, 51: 196-208, 1958.

MORI, C.M.C.; BONOLDI, V.L.N.; VASCONCELOS, S.A.; BARROS-BATTESTI, D.M.; YOSHINARI, N.H. \& SCHUMAKER, T.T.S. Reprodução "in vivo" em 
camundongos da linhagem $\mathrm{C}_{3} \mathrm{H} /$ hepas das dificuldades diagnósticas da doença de Lyme no Brasil. Rev. Bras. Reumatol, 36: S276, 1996.

NAGORSEN, D.W. \& PETERSON, R.L. Mammal collector's manual. Toronto, Ontario Mus. Life Sci. Contribut, 1980.

NAKAO, M. \& MIYAMOTO, K. Isolation of spirochetes from japanese ixodid ticks, Ixodes tanuki, Ixodes turdus and Ixodes columnae. Jpn. J. Sanit. Zool., 44: 4955, 1993.

NAKAO, M. \& MIYAMOTO, K. Susceptibility of Ixodes persulcatus and I. ovatus (Acari:Ixodidae) to Lyme disease spirochetes isolated from humans in Japan. J. Med. Entomol., 31: 467-73, 1994.

NORRIS, S.J.; HOWELL, J.K.; GARZA, S.A.; FERDOWS, M.S. \& BARBOUR, A.G. High- and low-infectivity phenotypes of clonal populations of in vitrocultured Borrelia burgdorferi. Infect. Immun., 63: 2206-12, 1995.

NORRIS, D.E.; KLOMPEN, J.S.H.; KEIRANS, J.E.; LANE, R.S.; PIESMAN, J. \& BLACK, W.C.IV. Taxonomic status of Ixodes neotomae and I. spinipalpis (Acari: Ixodidae) based on mitochondrial DNA evidence. J. Med. Entomol., 34: 696-703, 1997.

OBA, M.S.P. \& BAGGIO, D. Ocorrenncia de Ornithodoros talaje Guérin et Meneville, 1849 (Ixodides: Argasidae), na localidade de Santo Inacio, Bahia, Brasil. Arq. Inst. Biol., 44: 107-9, 1977.

OBA, M.S.P. \& SCHUMAKER, T.T.S. Estudos da biologia de Amblyomma rotundatum (Koch, 1844), em infestações experimentais de Bufo marinus (L., 1758) sob condições variadas de umidade relativa e de temperatura do ar. Mem. Inst. Butantan, 47/48: 195-204, 1983.

O'CONNELL, M.A. Population dynamics of neotropical small mammals in seasonal habitats. J. Mammal., 70: 532-48, 1989.

OLIVER Jr., J.H. Symposium on reproduction of arthropods of medical and veterinary importance. IV. Reproduction of ticks (Ixodoidea). J. Med. Entomol., 11: 2-26, 1974. 
OLIVER Jr., J.H. Biology and systematics of ticks (Acari: Ixodida). Annu. Rev. Ecol. Syst, 20: 397-430, 1989.

OLIVER Jr., J.H. Lyme borreliosis in the southern United States: a review. J. Parasitol., 82: 926-35, 1996.

OLIVER Jr., J.H.; STALLKNECHT, D.E.; CHANDLER Jr., F.W.; JAMES, A.M.; MCGUIRE, B.S. \& HOWERTH, E.W. Detection of Borrelia burgdorferi in laboratory- reared Ixodes dammini (Acari: Ixodidae) fed on experimentally inoculated white-tailed deer. J. Med. Entomol., 29: 980-4, 1992.

PAGLIA, A.P.; DE MARCO Jr., P.; COSTA, F.M.; PEREIRA, R.F. \& LESSA, G. Heterogeneidade estrutural e diversidade de pequenos mamíferos em um fragmento de mata secundária de Minas Gerais, Brasil. Rev. Bras. Zool., 12: 67-79, 1995.

PEREIRA, J.S.C. \& BUSSAB, W.O. Bussab \& Severo tabela de números aleatónios. São Paulo, Harbra Harper \& Row do Brasil, 1985.

PERSING, D.H.; TELFORD, S.R.; RYS, P.N., et al. Description of Borrelia burgdorferi DNA in museum specimens of Ixodes dammini ticks. Science, 249 : 1420-3, 1990.

PIESMAN, J. Intensity and duration of Borrelia burgdorferi and Babesia microti infectivity in rodents hosts. Int. J. Parasitol., 18: 687-9, 1988.

PIESMAN, J.; MATHER, T.N.; SINSKY, R.J. \& SPIELMAN, A. Duration of tick attachement and Borrelia burgdorferi transmission. J. Clin. Microbiol., 25: 557$8,1987$.

PINTO, C. \& PRIMO, R. Contribuição para a biologia dos Ixodidae ao Estado do Rio Grande do Sul (Brasil). Rev. Médico-Cirúrgica do Brazil, 34: 5-6, 1931.

POKORNY, P. Vyskyt spirochety Borrelia burgdorferi u clenovcu (Artrhopoda) a protilatek u obrathoveu (Vertebrata). Cesk. Epidemiol. Mikrobiol. Imunol., 38 : 52-60, 1989.

PONÇANO, W.L.; CARNEIRO, C.D.R.; BISTRICHI, C.A.; ALMEIDA, F.F.M. \& PRANDINI, F.L. Mapa geomorfológico do Estado de Sáo Paulo. São Paulo, Instituto de Pesquisas Tecnológicas do Estado de São Paulo, 1981. 
RANDOLPH, S.E.; GERN, L. \& NUTTALL, P.A. Co-feeding ticks: epidemiological significance for tick-borne pathogen transmission. Parasitol. Today, 12: 472-9, 1996.

RIBEIRO, S.S. Ixodides encontrados no Paraná. An. Fac. Med. Univ. Parana, 9/10: 7-51, 1966/1967.

SCHMID, G.P. The global distribution of Lyme disease. Rev. Infect. Dis., 7: 41, 1985.

SCHUMAKER, T.T.S. \& BARROS, D.M. Notes on the biology of Amblyomma dissimile Koch, 1844 (Acari: Ixodida) on Bufo marinus (Linnaeus, 1758) from Brazil. Mem. Inst. Oswaldo Cruz, 89: 29-31, 1994.

SCHUMAKER, T.T.S. \& BARROS, D.M. Life cycle of Ornithodoros (Alectorobius) talaje (Acari:Argasidae) in laboratory. J. Med. Entomol., 32: 249-54, 1995.

SCHWAN, T.G.; BURGDORFER, W. \& GARON, C. Changes in infectivity and plasmid profile of the Lyme diseases spirochete, Borrelia burgdorferi, as a result of in vitro cultivation. Infect. Immun., 56: 1831-6, 1988.

SETZER, J. Os solos do Estado de São Paulo. São Paulo, Biblioteca geográfica brasileira, IBGE-Conselho Nacional de Geografia, 1949.

SIEGEL, S. Estatistica não-paramétrica para as ciências do comportamento. São Paulo, McGraw-Hill do Brasil, 1977.

SIGAL, L.H. Summary of the sixth international conference on Lyme borreliosis. Arthritis Rheum., 38: 565-9, 1995.

STALLINGS, J.R. Small mammal inventories in na eastern Brazilian park. Bull. FI. State Museum. Biol. Sci., 34: 153-200, 1988.

STEERE, A. C. Medical progress. Lyme disease. N. Engl. J. Med., 321: 586-96, 1988.

STEERE, A.C. Lyme disease. New England. J. Med., 321: 586-596, 1989.

STEERE, A.C. Lyme disease: a growing threat to urban populations. Proc. Nat. Acad. Sci., 91: 2378-83, 1994.

STEERE, A.C. \& MALAWISTA,S.E. Cases of Lyme disease in the United States: 
locations correlated with distribution of Ixodes dammini. Ann. Intern. Med.,91: 730-3, 1979.

STEERE, A.C.; BRODERICK, T.F. \& MALAWISTA, S.E. Erythema chronicum migrans and Lyme arthritis: epidemiologic evidence for a tick vetor. Am. J. Epidemiol., 108: 312-21, 1978.

STEERE, A.C.; GRODZICKI, R.L.; CRAFT, J.E.; SHRESTA, M.; KORNBLATT, A.N. \& MALAWISTA, S.E. Recovery of Lyme disease spirochetes from patients. Yale J. Biol. Med., 57: 557-60, 1984.

TAKADA, N.; ISHIGURO, F.; IIDA, H.; YANO, Y. \& FUJITA, H. Prevalence of Lyme borrelia in ticks, especially lxodes persulcatus (Acari:lxodidae), in Central and Western Japan. J. Med. Entomol., 31: 474-8, 1994.

TALHARI, S.; TALHARI, A.C. \& FERREIRA, L.C.L. Eritema cronicum migrans, eritema migratorio, doença de Lyme ou borreliose de Lyme. An. Bras. Dermatol., 67: 205-9, 1992.

TELFORD, S.R. III; MATHER, T.N.; MOORE, S.I; WILSON, M.L. \& SPIELMAN, A. Incompetence of deer as reservoirs of the Lyme disease spirochete. Am. J. Trop. Med. Hyg., 39: 105-9, 1988.

VICKERY, W.Z. \& BIDER, J.R. The influence of weather on rodent activity. J. Mammal., 62: 140-5, 1981.

VIEIRA, C. Roedores e lagomorfos do Estado de São Paulo. Arq. Zool., 8: 12967, 1953.

VIEIRA, C. Lista remissiva dos mamiferos do Brasil. Arq. Zool., 8: 341-487, 1955.

VILLALOBOS-DOMÍNGUEZ, C. \& VILLALOBOS, J. Atlas de los colores. Buenos Aires, EI Ateneo, 1947.

WILLS, M.C. \& BARRY, R.D. Detecting the cause of Lyme disease in Australia. Med. J. Aust., 155: 275, 1991.

WOOLLEY, T.A. Acarology. Mites and human welfare. Fort Collins, Library of Congress, 1987. 
YOSHINARI, N.H.; STEERE, A.C.; COSSERMELLI, W. Revisão da borreliose de Lyme. Rev. Assoc. Med. Bras., 35: 34-8, 1989.

YOSHINARI, N.H.; BARROS, P.J.L.; YASSUDA, P.; BAGGIO, D. \& COSSERMELLI, W. Estudo Epidemiológico da doença de Lyme no Brasil. Rev. Hosp. Clin. Fac. Med. S. Paulo., 47: 71-5, 1992.

YOSHINARI, N.H.; STEERE, A.C.; BARROS, P.J.L., et al. Lyme disease in Brazil: report of five cases. Rev. Esp. Reumatol., 20: 156, 1993a.

YOSHINARI, N.H.; STEERE, A.C.; BARROS, P.J.L., et al. Lyme disease sorology in Brazil. ELISA or Western blotting? Rev. Esp. Reumatol., 20: 473, 1993b.

YOSHINARI, N.H.; BARROS, P.J.L.; STEERE, A.C., et al. Epidemiological study of Lyme disease in Cotia. Rev. Esp. Reumatol., 20: 474, 1993c.

YOSHINARI, N.H.; STEERE, A.C.; BARROS, P.J.L., et al. Sorology for the Lyme disease in infectious and diffuse connective diseases in Brazil. Rev. Esp. Reumatol., 20: 474, 1993d.

YOSHINARI, N.H.; BARROS, P.J.L.; FONSECA, A.H., et al. Borreliose de Lyme zoonose emergente de interesse multidisciplinar. Newslab., 12: 90-104, 1995. YOSHINARI, N.H.; BARROS, P.J.L;; BONOLDI, V.L.N., et al. Perfil da borreliose de Lyme no Brasil. Rev. Hosp. Clin. Fac. Med. S. Paulo., 52: 111-7, 1997.

YUVAL, B. \& SPIELMAN, A. Duration and regulation of the developmental cycle of Ixodes dammini (Acari: Ixodidae). J. Med. Entomol., 27: 196-204, 1990.

ZAR, J.H. Biostatistical analysis. Englewood Cliffs, Prentice-Hall, Inc., 1974.

ZOTZ, C. Contribuição à ecologia e sistemática de Cricetidae (Mammalia, Rodentia) de Piraquara, Paraná, Brasil, 1985. [Dissertação de Mestrado Setor de Ciências Biológicas da Universidade Federal do Paraná]. 